\title{
The Politics of War: Race, Class, and Conflict in Revolutionary Virginia
}

Robert G. Parkinson

William \& Mary

Follow this and additional works at: https://scholarworks.wm.edu/aspubs

\section{Recommended Citation}

Parkinson, R. G. (2009). The Politics of War: Race, Class, and Conflict in Revolutionary Virginia-By Michael A. McDonnell. Historian, 71(1), 120-121.

This Article is brought to you for free and open access by the Arts and Sciences at W\&M ScholarWorks. It has been accepted for inclusion in Arts \& Sciences Articles by an authorized administrator of W\&M ScholarWorks. For more information, please contact scholarworks@wm.edu. 
(C) 2009 Phi Alpha Theta

\title{
Book Reviews
}

Editorial Office: Elliott Hall IV, Ohio Wesleyan University; Delaware, OH 43015. Telephone: 740-368-3642. Facsimile: 740-368-3643.

E-MAIL AdDREss: brhistor@owu.edu

WeB AdDREss: http://go.owu.edu/ brhistor

\author{
EDITOR \\ Richard Spall \\ Ohio Wesleyan University \\ Regional Sub-Editors
}

Robert Dietle

(Modern Western Europe)

Western Kentucky University

Richard B. Allen

Douglas R. Bisson

(Early Modern Europe)

Belmont University

(Africa, Middle East, and South Asia)

Framingham State College

Helen S. Hundley

(Russia and Eastern Europe)

Wichita State University

Betty Dessants

(United States Since 1865)

Shippensburg University

Jose C. Moya

(Latin America)

University of California at Los Angeles

Nigel Kennell \& Stefanie Kennell

(Ancient World)

Memorial University of Newfoundland

Susan Mitchell Sommers

Paulette L. Pepin

(Medieval Europe)

(Britain and the Empire)

Saint Vincent College

Richard Spall
(Historiography)

Sally Hadden

(United States)

Florida State University

University of New Haven

Peter Worthing

(East Asia and the Pacific)

Texas Christian University

Student Editorial Assistants

Senior Editorial Assistants

Scarlett Rebman

Kara Reiter

Janna Dagley

Kaleigh Felisberto

Colin Magruder

Eric Francis

Kristina Fitch

Neill McGrann

Zak Gomes

Mark Lovering

Greg Stull

Olivia Talbott

Jeffrey O'Bryon

Abraham Gustavson

Word Processing: Laurie George 


\section{AfRICA AND THE MIDDLE EAST}

Ariel Sharon: An Intimate Portrait. By Uri Dan. (New York, N.Y.: Palgrave Macmillan, 2006. Pp. xvi, 292. \$16.95.)

Ariel Sharon, well known for his military and political roles over the course of Israeli history from 1948 to 2006 when he suffered a stroke, remains a figure who generates deeply held feelings and controversy. For some, he represents the best of Israel's daring and heroism; others view him as guilty of repeatedly provoking violence, and as responsible for initiatives-such as the settlement of occupied territories and the Lebanon War of 1982-that intensified conflict, thereby undermining any possibility for negotiated peace. Some consider him a war criminal as well.

The author of the book reviewed here does not in any way contribute to readers' understanding of this complex figure or his impact on history. Uri Dan's subtitle suggests entry into a more personal grasp of Ariel Sharon, but it would be more accurate to call this a portrait based on hero worship and hope for admiration based on basking in Sharon's reflection. The author, a longtime friend and spokesperson for Sharon, offers his own narrative and unpublished interviews, but none of the material can actually be verified or evaluated without significant further research as the book contains neither footnotes nor bibliography. At best, this is a personal tribute of love by a follower who may hope to affect the way this history is written.

Although it will take time and distance to permit a historically sound evaluation of Sharon's impact on Israeli history, there is no doubt that his biography encompasses a lifetime of efforts to remain close to military and political action. In the early years of statehood, Sharon led a commando group of the Israel Defense Forces, which undertook reprisal actions against Arab villagers over the border. One incident, in Qibya on the West Bank, in particular gained attention for its destructiveness and civilian deaths. Other military actions reinforced Sharon's reputation for aggressive initiatives.

Eventually he became the Minister of Defense largely responsible for the Lebanon War of 1982 and notorious for his role in the Sabra and Shatilla massacres. Even before, however, he was a powerful force in creating the density of Israeli settlements in occupied territories, which remain a significant obstacle to negotiated peace efforts. Despite the fact that one of his last acts as Prime Minister was the removal of settlements from Gaza, most who followed Sharon's career had doubts as to whether this effort represented a change of heart or simply another tactical effort. 
For Dan, Sharon was "the man who most embodied Israel's destiny" (Foreword). There is little doubt that Sharon's life was intimately and intricately bound up with the state for which he fought, but this book unfortunately provides readers with little insight into the meaning of that relationship beyond an idealization, which in itself is perhaps best understood as part of that history.

Duke University

Ylana Miller

Locality, Mobility, and "Nation": Periurban Colonialism in Togo's Eweland, 19001960. By Benjamin N. Lawrance. (Rochester, N.Y.: University of Rochester Press, 2007. Pp. xv, 288. \$75.00.)

This author responds to the frequent failure of past histories of African nationalism to include the roles of "multiple human and territorial constituencies" in the exploration of the development of ethnic and territorial nationalism while accepting that independence struggles were nationwide phenomena. Benjamin $\mathrm{N}$. Lawrance expands the analysis of ethnic and territorial nationalism beyond its conventional exaggeration of urban, male, and elite power as the engines driving the process. By integrating the city and its surrounding rural areas into his analysis, his study of French Togo overcomes the limitations of narratives about state, power, and invented tradition, which overstate the roles of chieftaincies while understating the importance of rural populations in the nascence of anticolonialism.

Locality, Mobility, and "Nation" is most assuredly a political history tracing the evolution of an independence movement culminating in the birth of the Republic of Togo in 1960 after Sylvanus Olympio, its first president, led decolonization efforts. But it is far more than that. It is a deeply nuanced interdisciplinary study integrating gender, social, and political history. Lawrance's narrative encompasses urban and rural interaction, the role of market women in the genesis of Ewe ethnic nationalism, and the transformation of ethnic nationalism into territorial nationalism. It is a well-crafted history of German Togoland come under French rule by way of the League of Nations Mandate. That mandate administratively divided the Ewe people between France and Britain. Examining the intricacies of urban connections and interdependencies with surrounding rural areas, Lawrance provides a superior account of the economic, social, and political tensions that shaped the events and circumstances leading from the growth of Ewe nationalism to the forging of the broader conception of territorial Togo.

Having laid down the context and circumstances of the evolving French colonial milieu in the Mandate era, including its consequent adjustment to inter- 
national oversight, Lawrance turns to the analysis of the developments leading to the market women's revolt in 1933. Presenting it as the first overt expression of reaction to French tax policy changes, market day alterations, selection of councils, and appointment of chieftains, he examines the complexities of Vodou as an Ewe means of reclaiming political authority, first by women, then by African males. He insightfully analyzes the adjustments of the colonial government to a growing resistance at the urban and rural junctures complicated by the porous border between Gold Coast and Togo across which travel dissenters and dissents. His closing chapter constitutes a fine synthesis of the entire period culminating in the exploration of the print media's role in promoting territorial nationalism.

In this well-researched and thoroughly documented work, the author offers new perspectives on anticolonialism in terms of the integration of urban centers and the surrounding rural communities, which together constitute the "periurban" zones. African and colonial scholars alike will benefit from this groundbreaking work.

Boise State University

Peter Buhler

The Development of Trans-Jordan 1929-1939: A History of the Hashemite Kingdom of Jordan. By Maan Abu Nowar. (Reading, England: Ithaca Press, 2006. Pp. xii, 392. \$66.00.)

This is the fourth volume in the series "A History of the Hashemite Kingdom of Jordan." A former Major-General in the Jordanian army, diplomat, and politician, the author earned a D.Phil at Oxford, which was the basis for the first volume, The Creation and Development of Transjordan 1920-1929. He later published The Struggle for Independence 1939-1947 and The Jordanian Israeli War 1948-1951. With the current volume, Maan Abu Nowar has completed a continuous narrative history of the Emirate of Trans-Jordan (later, the Kingdom of Jordan), which lasted more than three decades.

The author's main message is that the 1930s constituted a formative period for Trans-Jordan. In the 1920s, the new entity was established, its boundaries were contoured, its relations with Great Britain were institutionalized, and the status of its ruler, Abdullah, was defined. In the 1930s, Abdullah obtained legitimacy from the indigenous population and the neighboring countries both for the new territorial unit and for its authority over it.

This period was dedicated to state building and, simultaneously, was characterized by a slow and gradual progress towards independence: government 
departments began to function systematically and to provide public services; a rudimentary legislative authority emerged, accompanied by parliamentary and extra-parliamentary opposition activity.

The 1930s also witnessed the crystallization of Trans-Jordanian nationalism on the one hand and of anti-Zionist solidarity with the Palestinian Arabs on the other. Abu Nowar even observes "a small spark of Jordanian tribal nationalism" kindled by the threats of the Bedouin across the border (84). One of the government's contributions to the process of nationalism was the approval of a new national anthem (272).

In addition, the 1930s were characterized by social and economic changes and by the emergence of a nascent urban class stratification: workers, civil servants, soldiers, merchants, with some high school students and teachers and a few university graduates who, according to Abu Nowar, symbolized the beginning of an intellectual elite.

The author endeavors to create the impression that even though Trans-Jordan was still a predominantly Bedouin and peasant society, as early as the 1930s, the political, economic, and social impact of the emanating urban middle class began to have an effect and to shape the more elaborated characteristics of the new national entity.

The main advantage and, paradoxically, the disadvantage of this book is the huge amount of detailed, informative data that it contains-from lists of intertribal raids and the number of camels lost in each one, to the names of signatories on a marginal petition. Nevertheless, this is by no means a reference book but, as the author perceives it, a record of the historical development of Trans-Jordan. As such, this volume would have benefited from a greater balance between the impressive amount of data and the descriptions and analyses of the course of events.

George Lenczowksi once wrote that in the first half of the 1930s in Egypt "there was no political history to record." In a way, Abu Nowar goes the other way around. Even though at that time there were fewer political developments in Trans-Jordan than in Egypt, he portrays a wide, intensive, and detailed picture of the internal and external activities in and around Emir Abdullah's new realm.

Nevertheless, this book is valuable for the non-Arabic-speaking readership as it provides, besides the author's insights, much information that cannot be found in any other nonarchival source or publication in English. 


\section{The AMericas}

Critical Americans: Victorian Intellectuals and Transatlantic Liberal Reform. By Leslie Butler. (Chapel Hill, N.C.: University of North Carolina Press, 2007. Pp. xv, 381. \$24.95.)

Meet four of American history's “deadest, whitest, least manly men," in the coy words of their collective biographer (6). The writers and activists James Russell Lowell, Thomas Wentworth Higginson, Charles Eliot Norton, and George William Curtis may have been four of the most prolific, wide-ranging, and famous Victorians in nineteenth-century America, but, for at least forty years, the academy has classed them with the effete, elitist, and out of touch: tea-sipping armchair intellectuals too genteel to get real and too busy with manners to notice what was the matter with industrialism and all its social disorder.

Leslie Butler generously acknowledges the grains of truth on which this cartoonish dismissal rests, but she arduously reconstructs these thinkers' concerns with slavery, democracy, and American power in order to argue for their importance in their own time and continuing relevance in ours. In this book, Butler demonstrates how the literary work of these "Victorian liberals" operated as an instrument of political and social reform, how their youthful radicalism did not end with the abolition of slavery, but continued through their mugwumpery and beyond, and how their personal and professional ties with contemporary British liberals created a vital arena of engaged reformism. Butler's cohort of dead white men turn out to be cosmopolitan critics of American imperialism whose broadminded advocacy of "educative citizenship" stemmed from a Romantic, postUnitarian "cultural style" in which aesthetic, moral, and literary excellence all contribute to the health and success of democratic society $(119,94)$. It seems that their emphasis on "cultivation," particularly of the arts, was not elitist at all. Instead the critical Americans represented a progressive, cultural liberalism that was neither atomistic nor possessive but positive and universalistic (7).

Butler generates her portrait of the Victorian liberals, their post-Civil War "high tide," and their futile resistance of American imperialism in the Philippines from a thorough reading of the liberals' correspondence, voluminous published writings, and an impressively comprehensive digestion of the relevant secondary literature. Her analysis, though written in lively, accessible language, assumes significant knowledge on the reader's part; she had to economize on explaining Alexis de Tocqueville's 1830s critique of American culture, for example (as well as the Trent affair, the Paris Commune, and the politics of Benjamin Disraeli), so 
that she could give more space to Higginson's Civil War service, Curtis's denunciations of Thomas Carlyle's conservative spume, Lowell's advocacy of female suffrage, Norton's friendship with Leslie Stephen, the Morant Bay massacre, and all four liberals' camaraderie with prominent British reformers, particularly J. S. Mill and Matthew Arnold. She also slights religion, which helps make Higginson, a massive figure in postwar religious liberalism, fit better with his more secular peers but misses a crucial valence of culture itself.

These are not criticisms so much as delimits of the project she accomplishes so well here. Throughout the book, Butler is concerned with both acknowledging her liberals' social views and examining their moral meaning. She notes how her one-time abolitionists ended up reconciling themselves to reconciliation not only with the South for the sake of the Union, but also with Confederate sympathizers, like John Ruskin (whose papers Norton edited and published), for the sake of ... what? Butler's frequent admissions of her liberals' "blind spots," moderated with qualifiers_-"although," "however," "admittedly"—admirably highlight evidence contrary to her overall interpretation, but the question remains: how could these so-called liberals clasp hands so easily across that bloody chasm?

Sonoma State University

Amy Kittelstrom

The Scratch of a Pen: 1763 and the Transformation of North America. By Colin G. Calloway. (New York, N.Y.: Oxford University Press, 2006. Pp. xvii, 219. \$15.95.)

This is a very satisfying addition to the Pivotal Moments in American History series edited by David Hackett Fischer and James M. McPherson. The prolific Colin G. Calloway provides historians and their students with a less-traveled route by which to move through the decades between the 1763 Peace of Paris and the "Peace" negotiated in Paris twenty years later. A formidable variety of individuals and groups have replaced the familiar names from accounts centered on the struggle between Great Britain and the thirteen colonies. Arguing that historians "have often neglected actors and scenes that did not contribute to this central plot," Calloway promises to explore the "dissenting voices, unforeseen responses, racial conflicts, and human dislocations" that spawned turmoil as word of the Treaty and later the Proclamation Line of 1763 spread across the continent (177).

The adaptation of people to changed or changing circumstances is an obvious or underlying theme for many or most historical studies. Calloway presents a remarkably clear and learned account of how people tried to adapt to changes 
resulting from the Seven Years' War, and in particular from the Treaty of 1763 and the Proclamation Line.

It was of course the British government's effort to adapt to its new imperial role that led to the campaign for colonial revenues and to the "central plot" historians customarily retell. Great Britain tried to adapt, but it failed, dividing the empire in the process. Especially complex among the would-be adaptors were a plethora of Indian nations and tribes.

Calloway points to the breakdown of "forced alliances and built patterns of coexistence" between Indians and Europeans during the warring 1760s (15). As in the aftermath of King Philip's War in New England in 1675-1676, the Seven Years' War "left a bitter legacy and assured a bloody future" in which "the violence was increasingly racial" (16).

After setting the 1763 stage in his first chapter, Calloway, in chapter two, covers Pontiac's War, "which dominated the year from spring to fall" (17). Chapter three examines the impact of the war on Indians, settlers, and soldiers and the increasing efforts to define boundaries and to separate Indians and whites. In chapter four, the author focuses on the Proclamation of 1763 and the Treaty of Augusta [1763] with some southern Indians. Although designed to assert control, they "ultimately widened the gulf between British officials and colonial Americans" (17). The author addresses French America in Quebec, the Illinois country, and the Mississippi Valley in chapter five. Chapter six takes up changes in the lower Mississippi Valley and Louisiana. In chapter seven the author examines Anglo-American occupation of the southeast and the expansion of African American slavery. He also discusses how the Spanish desire to attract settlers to Louisiana opened opportunities for the French-speaking Acadians.

This book will enlighten many people who thought they had a reasonably solid grasp of this period in American history.

Assumption College

Kenneth J. Moynihan

Case Closed: Holocaust Survivors in Postwar America. By Beth B. Cohen. (New Brunswick, N.J.: Rutgers University Press, 2007. Pp. xv, 223. \$44.95.)

In this well-documented study, drawing on archival materials, case files, and oral testimonies, the author probes the difficult transition that survivors, arriving as refugees under displaced persons legislation, experienced in postwar America. About 140,000 Jewish refugees settled in the United States by 1954. Several themes emerge, including the priority given to Jewish agency goals working with newcomers regardless of their special needs, de-emphasis on health and psycho- 
logical issues, feelings of isolation among many newcomers, and nascent efforts by survivors to communicate and commemorate.

The general portrait Beth B. Cohen draws is not pretty. Although American Jews and Jewish agencies sought to help the refugees, they did so without deep feeling for or understanding about their needs. Even most sponsor families provided neither consistent financial nor human support: the pattern was "limited help to outright indifference to active rejection" (49). Agencies emphasized finding quick paths to employment and self-sufficiency over dealing with human needs. Special tensions marked efforts to assist Orthodox Jews, who were thought to be exceedingly demanding. Lack of empathic understanding also shaped responses to adolescent orphans, who had suffered great losses and learned aggressive coping behaviors in Nazi Europe.

Cohen says that the contemporary impression was of "quick and successful adaptation" by the newcomers, and she points out that sociologist William Helmreich in Against All Odds [1995] concluded similarly. They emphasized the long-term triumph by survivors in rebuilding new lives in America. In contrast, Cohen argues that the reality in the early years was more complicated, and readers can see this if they think of the arrivals as multiple selves-that is, as refugees adapting to a new society, but also as survivors carrying burdens of trauma and anguished memories. Jewish social workers communicated that they simply should not spend too much time thinking about the past. Issues of illness and difficult readjustment loom large in the files, Cohen reports. She concludes that agency caseworkers "exhibited nearly universal blindness" to their charges as survivors.

In the best chapter, Cohen analyzes the state of psychological knowledge regarding survivors in the late 1940s and the 1950s, as well as the new awareness of problems of emotional apathy (affective anesthesia) and of survivor guilt. But the predominance of Freudian models minimized comprehension of the catastrophe's deepest human impacts. Social workers knew no better, generally urging clients to forget.

Cohen writes that the need of survivors to dwell in the past, to grieve, and to remember, as well as to embrace the future, was served primarily by their own efforts. Memory was served as landsmanschaftn produced yizkor books, newcomer associations memorialized losses and created monuments, and individuals wrote memoirs in Yiddish.

In Case Closed, the author argues that Holocaust survivors were not welcomed warmly initially, nor were their burdens fully comprehended. They were dealt with as newcomers, not survivors of genocide. But Cohen goes too far in saying 
Americans or American Jews "should have responded differently" (174). As the Holocaust looms larger today, and as psychological knowledge about trauma deepens, Americans comprehend better in hindsight the shortcomings of the initial response than contemporaries could during the 1950s. Thanks to Case Closed, though, readers better appreciate that becoming Americans for the new arrivals was no easy road.

Michigan State University

Kenneth Waltzer

People of the Volcano: Andean Counterpoint in the Colca Valley of Peru. By Noble David Cook with Alexandra Parma Cook. (Durham, N.C.: Duke University Press, 2007. Pp. xv, 319. \$23.95.)

This study explores the colonial history of the Andean region through the lens of early interactions between various Spanish and indigenous peoples in the Colca Valley of southern Peru. The authors deftly employ microregional analysis of the Colca Valley to illustrate the quotidian effects of decisions made by Spanish colonial authorities at all levels in the administrative hierarchy.

This approach is most successfully carried out in the case of Toledan reforms and reducciones. This Spanish strategy forcibly relocated native Andeans into densely populated villages to control and exact tribute from them more effectively. The authors document the social implications and unintended consequences of this policy at the local level. For example, disease transmission and mortality rates increased because of the increased population density, thus diminishing the economic returns to the Spanish crown. This also initiated a norm shift from ayllu (kin-based autonomous units of production) endogamy to saya (spatially structured halves of regions or villages) endogamy. These reduced populations made it more difficult to find appropriate partners within one's ayllu, and the reducciones brought geographically distant ayllus together, thus facilitating ayllu exogamy.

The book serves well as a rich ethnohistorical account of Andean communities in early colonial times. The authors' descriptions of these communities' social, political, and economic institutions are particularly well written, informative, and entertaining, reading much like a traditional structuralist ethnography. Social taxonomies, marriage norms, punishment rules, subsistence strategies, religious beliefs, and movements responding to colonial contact are all documented with amazing detail thanks to the authors' creative use of multiple lines of evidence. For example, from census records they use adoption of Christian names as proxies for ideology adoption and culture change, and demographic data to track population dynamics and the magnitude of epidemics. They also incorporate archaeological 
data and cautious analogy with contemporary informants' ethnographic descriptions to fill out the particulars of colonial Colca life. Another indication that the authors' aim is an accurate description of this society is their willingness to entertain multiple causal mechanisms as explanations for complex phenomena. Demographic, ecological, and cultural inertia; ideology; and rational economic self-interest are all considered as explanatory frameworks in different sections of the book.

The methodological pluralism is mostly alluded to, or inferred by the reader, but not detailed. Noble David Cook and Alexandra Parma Cook provide glimpses of their rich data set throughout the book, but do not describe it or consider its potential biases. Therefore, readers wishing for an opportunity to analyze the work's methodological rigor will be left unsatisfied and may wish to refer to the authors' other demographic analyses. There is often an exchange between ease of legibility and methodological specificities. Throughout the book the latter is seldom missed.

The slight exception may be in the comparison of Incan and Spanish colonial tax systems. Here the authors make their boldest claim, maintaining that Spanish tribute was more abusive than the Incan mitayo. Additionally, only the former did not fit Andean notions of reciprocity and was thus perceived as more unjust by local Colca villagers, even though both were imposed by external imperial powers. Although the claim resonates with anticolonial sentiments and the data they provide, the different sources of information used for precolonial and postcolonial periods may introduce biases that make such strong interpretations difficult. Colonial historical archaeology, often underrepresented in the social sciences of the Andes, may provide another line of evidence with which to test such claims.

University of California, Los Angeles

Cristina Moya

Lincoln's Man in Liverpool: Consul Dudley and the Legal Battle to Stop Confederate Warships. By Coy F. Cross II. (Dekalb, Ill.: Northern Illinois University Press, 2007. Pp. x, 180. \$28.95.)

With more than sixty thousand titles on the topic and still counting, the American Civil War continues to elicit a vast and varied scholarly literature, with the result that few figures of note during the conflict have managed to escape multiple biographers. Thomas H. Dudley-U.S. consul in Liverpool, England, throughout the war-is a case in point. Although not many historians would recognize his name today, Lincoln's Man in Liverpool is actually the second biography of Thomas Dudley to appear in the last four years. Both David H. Milton's Lincoln's 
Spymaster and Coy F. Cross's more recent study point to Dudley's vital role in U.S.-British relations during and immediately after the war. Whereas Milton emphasizes Dudley's part in coordinating espionage activities, Cross stresses Dudley's efforts to build a legal case that would block British shipbuilders from constructing warships for the Confederate navy.

Following the outbreak of war, Confederate authorities recognized that the South could never build a viable navy on its own and looked instead to England to build commerce raiders that could terrorize Northern shipping and ironclad rams that could break the Union blockade. This put Dudley in a crucial position, for Liverpool was not only at the center of British shipbuilding, but was also decidedly pro-Southern in its sympathies. Under the British Foreign Enlistment Act of 1819, British shipbuilders were prohibited from "equipping and arming" warships for use by belligerents, but British authorities were hesitant to interfere with the shipbuilding industry and British courts consistently interpreted the Enlistment Act narrowly, ruling that construction of potential warships was permissible provided that the actual arming of the vessels occurred outside of Britain. In this frustrating environment, Dudley labored tirelessly to compile affidavits and amass other forms of evidence to establish the Confederate ownership and warlike intentions of various vessels under construction by Liverpool firms. Although Dudley's early efforts were in vain-as witnessed by the completion of the notorious commerce raiders CSS Florida and CSS Alabama-Cross contends that the evidence that the consul provided during the war contributed to a more amenable British policy after the spring of 1863, whereas the evidence that he continued to compile for several years after the war influenced the resolution of the so-called "Alabama Claims" by the United States against Great Britain in 1872. Unfortunately, Cross deals with the possible effects of the Emancipation Proclamation on British policy in the most cursory fashion, and his treatment of the handling of the Alabama Claims is similarly brief.

Cross grounds his observations in extensive archival evidence and offers a competent overview of Consul Dudley's efforts to block British shipbuilding for the Confederacy. The narrative is thorough-with separate chapters on Dudley's efforts to block the building of the Florida, the Alabama, the Alexandra, the Laird ironclads, etc.- - but readers will likely find it short on imagination and analysis. The main characters in the story, even Dudley himself, are largely twodimensional, and the author is more successful at describing the outcome of Dudley's "legal battle" than in explaining it. 
Imperfect Presidents: Tales of Misadventure and Triumph. By Jim Cullen. (New York, N.Y.: Palgrave Macmillan, 2007. Pp. 256. \$24.95.)

The author of this study has written a very readable book for people who are not familiar with presidential history. He provides more than description, however. Jim Cullen illustrates the importance of presidential "character" in leading the nation to follow, in Abraham Lincoln's words, "the better angels of our nature."

Cullen sees "character," which he defines implicitly by example, as a two-sided coin in that a president's virtues and flaws are intertwined, as with all of us. A central theme, which he illustrates with Thomas Jefferson, John Quincy Adams, Abraham Lincoln, Chester Arthur, Theodore and Franklin Roosevelt, and Ronald Reagan, is that presidents who fail initially in their performance may find ways to redeem themselves later with decisive action in hard situations. John Quincy Adams failed as president, but redeemed himself as an antislavery advocate in the House of Representatives. Ronald Reagan moved between purposeful vision and a weak sense of reality, but had the will to strike arms agreements. Lyndon Johnson, Bill Clinton, and George W. Bush do not fare well in their depictions.

Cullen makes some factual mistakes. Johnson did not address Congress asking for the Gulf of Tonkin Resolution. Dick Cheney was not in the House when Donald Rumsfeld pushed Gerald Ford for minority leader. Reagan was not an informer to the House Un-American Activities Committee. There are also questions of interpretation. For example, the reviewer finds it very unlikely that Reagan sought an arms agreement at the Reykjavik summit with Mikhail Gorbachev in order to ward off the impending scandal of the Iran-Contra affair. Cullen sees Iran-Contra as a watershed in the end of the Cold War, but his point is obscure.

The author does affirm that individual presidents may make a difference in history. This affirmation runs against the grain of much contemporary work in political science presidential studies. The conventional wisdom, relying on statistical analysis of large numbers of presidential recommendations to Congress and studies of presidential leadership of public opinion, is that presidents, at best, make a difference only at the margins. This approach fails to see that a relative few but decisive presidential actions may make all the historical difference. Cullen understands this.

Cullen concludes that the best presidents find ways to articulate and reflect in their personality and actions the very best spirit of the nation. In the final analysis he thinks it less important who is president than who we, the people, are. 
Slavery on Trial: Law, Abolitionism, and Print Culture. By Jeannine Marie DeLombard. (Chapel Hill, N.C.: University of North Carolina Press, 2007. Pp. xiv, 330. \$65.00.)

The rationale for what might be called the "market place of ideas" strategy for ending slavery by peaceful means is the application of the 1735 Zenger Rule, in which Philadelphia lawyer Andrew Hamilton (not Alexander as the author maintains, in a rare error) convinced New York jurors that they, rather than the judge, should determine what was libel. The point being that the Zenger jury was part of an influential segment of the community that could defy the colonial bureaucracy. This meant freedom of expression existed at the will of a community, that is, antislavery expression banned in slaveholding regions could at least exist, albeit in a limited way, in the North.

That the author may have been led astray by an authority on the law of freedom of expression is not censurable. The scope of her study has necessitated her reliance on specialists in a variety of fields, and her selection has held up quite well. The depth and breadth of her research and discerning literary comments are, moreover, impressive. After an introductory overview, Jeannine Marie DeLombard sets the stage for the trials by courts of public opinion made possible by the shift in attitudes between the 1830s and 1850s, at least to allow abolitionists to present the case against slavery. As she notes: "[T]he abolitionist campaign embraced the legal spectatorship popularized by the cheap press," which "was nevertheless motivated by a commitment to political change over financial profit" (56).

Black abolitionists, denied access as witnesses to slavery's brutality in Southern courts, sought to establish their credibility in the Northern court of public opinion. The formidable but not insurmountable obstacle of racial stereotype had to be overcome not only to receive a hearing, but also to be believed. Understandably, DeLombard focuses on Frederick Douglass and Isabelle Van Wagenen, on her way to becoming Sojourner Truth, in their struggles to attain credibility. The very magnitude of their conflicts points out the great difficulty of winning the battle of persuasion. The author provides a useful comparison between black and white abolitionists in the court of public opinion in her discussion of Harriet Beecher Stowe. Focusing on Dred rather than Uncle Tom's Cabin, DeLombard points out that avoiding the anticipated climax of a slave rebellion indicates Stowe's "awareness of the tendency of white advocacy to act as a check on black resistance," and to subscribe to it (172).

Fittingly, the book reaches a climax with the trial, execution, and martyrdom of John Brown: "[T] he most stirring of the era's sensational courtroom dramas" 
that "demonstrated the ultimate futility of law as print in providing a peaceful resolution to the national crisis" (208). In short, ending slavery peacefully through the force of reason was like Albion Tourgee's Reconstruction, "a fool's errand," but the story of racism's pervasiveness in the antebellum era needed to be told, and the author has told it well.

SUNY, New Paltz

Donald Roper

Harry S. Truman and the Cold War Revisionists. By Robert H. Ferrell. (Columbia, Mo.: University of Missouri Press, 2006. Pp. ix, 142. \$24.95.)

In a brilliant and concise work (a little over one hundred pages of text), the dean of American presidential historians delivers a critical commentary on the Cold War revisionists who tended to shift the blame for many of the Soviet-American encounters following World War II from the Soviet Union to the United States, from Joseph Stalin to Harry Truman. Robert H. Ferrell targets the works of Walter LaFeber, Gar Alperovitz, Lloyd Gardner, and other followers of William Appleman Williams at the University of Wisconsin, who viewed American aggressive (imperialistic) actions as creating and fomenting a defensive/offensive Soviet stance in response to the Truman Doctrine, the Marshall Plan, and the formation of NATO. Alperovitz is especially faulted for developing the theory of atomic diplomacy; that is, essentially waving "the bomb" in Stalin's face, when, in fact, the United States possessed very few. Ferrell defends, of course, the "traditionalists," such as John Lewis Gaddis and Richard Kirkendall, who were among the supporters of the Truman-Marshall-Kennan "appropriate" reactions to genuine Soviet threats made to the United States and particularly to areas of the world where its interests were already at stake, namely Western Europe, as well as in the Middle East and the Far East.

Ferrell accuses the revisionists, perhaps a bit unfairly, of forming a contrarian conclusion to the prevalent version of current affairs in the 1950s and then marshaling (or manufacturing) the evidence to support it, violating the accepted rules of historiography and making prominent use of some (even questionable) evidence while ignoring documents that might refute it. He emphasizes their impact on liberal (New Leftist) circles, even on popular historians, for example Stephen Ambrose, who found "containment" a codified view of American dominance. As an aside, Ferrell recalls a seminar in the 1950s at the University of Kansas, at which Williams promoted his interpretation of American imperialism and of its positive reception that meshed with the then current New Left dialogue. 
By focusing on the Truman administration, Ferrell brings personalities into the foreground, especially in the chapter on the Korean War and the President's conflict with Douglas MacArthur, which at the time was considered one of Truman's greatest failures. But in Ferrell's view, the president comes out well ahead of MacArthur and his flawed strategic thinking. The general is portrayed as an eccentric, perhaps senile, embarrassment, who clumsily and inappropriately recoined his version of an older phrase: "Old soldiers never die, they just fade away," to much applause in Congress and cheering in farewell parades. Ferrell benefits from more recent studies on the Korean War to show Soviet involvement in it, but also to describe the complicated triangle of the new Red China (and its concentration on Formosa), Kim Il-Sung's ambitions for South Korea, and the American diversion with respect to Europe and the Berlin Blockade. A misconceived American withdrawal from the peninsula, owing to military weakness and the attempted transfer of responsibility for the area to the United Nations, left an opening. Much of this, of course, is not new, but Ferrell's analysis of it is fresh and on target.

In an interesting concluding chapter, Ferrell reviews the literature on Truman and his administration, including his own. He notes the early impressionistic accounts, including, of course, Margaret Truman's, were lacking in scholarly research, and condemns the early popular works, especially Merle Miller's largely distorted Plain Speaking. He emphasizes the importance of David McCullough's biography that brought Truman back into the forefront of popular historical literature. Most of the earlier works on Truman's political role, Ferrell dismisses correctly for bias and lack of access to documents. The opening of the Truman papers and associated personal diaries in the 1980s, however, significantly after the major publications of the revisionists, made more objective assessments possible. The current appraisal of the Truman presidency, now among the top-rated quarter among all presidents, is the result. Yet, as a master historian should conclude, Ferrell sees more work is needed: "In evaluating Truman the historians by and large find themselves uncertain. They need more time before they come around to the right point of view," whatever that might be (108). This book will interest anyone in the period and the subject and should be required reading in graduate seminars and an inspiration to their participants for new work and insights on Harry Truman and the Cold War. 
Debating Vietnam: Fulbright, Stennis, and their Senate Hearings. By Joseph A. Fry. (Lanham, Md.: Rowman \& Littlefield, 2006. Pp. xi, 198. \$72.00.)

A narrowly focused study can yield rich interpretive dividends. So it proves in Joseph A. Fry's examination of a pair of Senate hearings challenging Lyndon Johnson's handling of the Vietnam War. In February 1966, a distinctly dovish Senate Foreign Relations Committee guided by J. William Fulbright heard critiques of the war from a former general (James Gavin) and a former diplomat (George Kennan) and grilled two influential participants in the decision to fight in Vietnam (Maxwell Taylor and Secretary of State Dean Rusk). In August 1967, the hawkish chair, John Stennis, of a hawkish Senate Preparedness Investigating Subcommittee pitted Secretary of Defense Robert McNamara against military leaders, including members of the Joint Chiefs of Staff, over the president's restrictions on the bombing of North Vietnam. In developing these two episodes, Fry has exploited the Fulbright and Stennis papers, along with other manuscript collections, the record of the hearings, and the broader Vietnam literature.

The two case studies set against the backdrop of deepening domestic doubts about the Vietnam War generally confirm but also at points deepen readers' understanding of the complex currents shaping those doubts. The Fulbright hearings gave legitimacy to public dissent while revealing to a nationwide audience, thanks to live television coverage, serious divisions within the foreign policy establishment. The effect was to accentuate the long downward slide in support for the war already underway by late 1965. The less famous Stennis hearings convened just as the public was coming to split evenly on whether the war was a mistake (with most of the disaffected favoring intensified military action, not a negotiated settlement). The Stennis hearings proved the last hurrah for the hawks; by early the next year, support for escalation began a steady downward trend.

Throughout this crisp, engaging treatment, Fry points his readers to broader implications. He reminds readers that the arguments rehearsed for and against the war at the time echo eerily in postwar histories and polemics, and he offers his own careful and usually convincing appraisal of those arguments. He highlights the tangle that civil-military relations had become. He carries forward a renewed interest among historians in the role of Congress and congressional dissenters arrayed against an imperial presidency. And he suggests with the lightest of hands how his subject remains pertinent today as Congress struggles to make itself relevant in the face of another major military intervention gone wrong. This 
account makes it is easier to understand why, once more, legislators find it hard privately to confront a mistake, even harder to articulate their doubts to the electorate, and harder still to devise some responsible and effective remedial action. Fry's adroit handling of these points makes this much more than a book about two sets of hearings from which specialists will learn. Those new to the war (including students) will find Fry's expert, tight, and accessible rendering an excellent introduction to big issues of lasting importance.

University of North Carolina at Chapel Hill

Michael H. Hunt

Lynching in the West: 1850-1935. By Ken Gonzales-Day. (Durham, N.C.: Duke University Press, 2006. Pp. xii, 299. \$22.95.)

In this study of lynching, the author focuses on minority groups-Native Americans, Hispanics, and Chinese-who were, similar to African Americans, particularly in the South, victims of lynch mobs in California between 1850 and 1935. Ken Gonzales-Day argues that white supremacy, racism, and bigotry were key motivations for the public hangings. Additionally, he challenges the concepts of frontier justice and actions of vigilance committees as accepted alternatives to legal methods of dispensing justice and punishment.

The author divides the book into five chapters. In chapter one, he presents an overview of the history of lynching and antilynching movements. In chapter two, the author examines capital punishment issues and the public's fascination with witnessing hangings. Issues regarding how racial matters and vigilantism are archived and articulated are discussed in chapter three. In chapter four, Gonzales-Day details the often turbulent relations between Anglos and California minorities, especially Hispanics, and demonstrates how the former viewed themselves as superior to the latter. In the final chapter, the author provides additional examples such as the activities of Joaquin Murrieta, California's "Robin Hood," detailing Anglo racial attitudes toward Hispanics as well as the impact of public hangings on those involved.

Lynching in the West contains over fifty illustrations, some in color, and three valuable appendices that list, among other items, the names, alleged crimes, and ethnicities of individuals hanged. Gonzales-Day does provide endnotes and a bibliography; however, several standard sources on frontier justice such as books by Robert Dykstra, Philip Jordan, and Joseph Rosa are not included. Moreover, Gonzales-Day fails to mention other studies specifically on lynching done by Dora Apel, Anne Rice, and Michael Pfeifer that challenge his assertion of the uniqueness of his book. Finally, a book on lynching should not confuse the proper usage of 
the words "hanged" and "hung"! Nevertheless, this book should be read by those interested in the subject and in the impact of racial profiling.

Fort Hays State University

Raymond Wilson

Spy Satellites and Other Intelligence Technologies that Changed History. By Thomas Graham Jr. and Keith A. Hansen. (Seattle, Wash.: University of Washington, 2007. Pp. ix, 162. \$14.95.)

At a time when the U.S. Intelligence Community (USIC) is undergoing a relentless bashing for intelligence failures and shortfalls, often by poorly informed congressional and media critics alike, receiving some informed perspective about important intelligence successes is refreshing. This author's new book on the historical contributions of the U.S. satellite program does exactly that.

This very readable and comprehensive primer, about one hundred and twenty pages in length, will appeal to the general reader while offering important insights for students of the larger history of the Cold War as well. It is coauthored by Thomas Graham Jr., a former general counsel with the Arms Control and Disarmament Agency, and Keith A. Hansen, a nuclear weapons expert, both of whom are U.S. intelligence professionals with decades of experience in world arms control and treaties. Using recently published works and a variety of government reports, the authors have produced an insightful examination of the unique importance of so-called "national technical means"-satellites in the struggle between the United States and the Soviet Union to control and later reduce nuclear weapons. In their view, the U.S. and Soviet "development of reconnaissance satellite systems, along with other collections technologies . . changed the course of history" (121).

Although taking a topical approach, the authors trace the historical impediments to effective checking of the arms race. They advance the argument that in the decades following World War II the gradual rapprochement between the two deeply suspicious superpowers could only have been achieved through the development of sophisticated satellite capabilities. U2 flights over the Soviet Union, though revolutionary and very productive for the United States, were, in fact, one-sided and viewed by the Soviet leadership as violations of both international law and their sovereignty. As satellite reconnaissance replaced high-altitude aircraft, their legal status likewise evolved, and with the successful negotiation of the first Strategic Arms Limitation Treaty (SALT), satellites were legitimized as useful tools for mutual verification. 
The authors tell an original story that examines the complex relationship of intelligence professionals to policymakers in the world of space reconnaissance. They investigate the larger role played by the U.S. satellite program beyond mere verification and inspection. They explain that the sophisticated capabilities of the U.S. satellites for quick detection of Soviet cheating gave the intelligence community the confidence to assure skeptical policymakers that arms reduction through negotiated treaties could be effectively enforced. In spite of SALT II, which the authors chalk up to the "presidential politics of 1980," the 1980s witnessed the passage of the Intermediate Nuclear Force (INF) Treaty that combined national technical means verification and, for the first time in history, on-site inspections (79). These successes, in turn, led to the first Strategic Arms Reduction Treaty (START) and later START II. In an age when the USIC is under serious scrutiny, Graham and Hansen have made a contribution that every reader should consider. Mercyhurst College Raymond J. Batvinis

Eisenhower, Science Advice, and the Nuclear Test-Ban Debate, 1945-1963. By Benjamin P. Greene. (Stanford, Calif.: Stanford University Press, 2007. Pp. xvii, 358. \$65.00.)

Historians of the Cold War are familiar with the mostly unsuccessful efforts of American presidents to halt the nuclear arms race well into the 1980s. President Eisenhower publicly lamented his disappointment at progress on arms control in his farewell address, which railed not only against the influence of the "military-industrial" complex, but against government-sponsored scientific research that threatened to make public policy the "captive of a scientifictechnological elite."

Other scholars have written about science advice in presidential administrations, but Benjamin P. Greene's account is the most thorough on the complicated role of scientists in the ongoing development of Eisenhower's test ban policies. Greene meticulously constructs the furious bureaucratic infighting over nuclear testing and the many twists and turns in resulting policy. Using exhaustive research, the author clearly shows how Lewis Strauss, chairman of the Atomic Energy Commission (AEC), backed by Edward Teller, Ernest Lawrence, and other scientists, often frustrated Eisenhower's persistent search for a comprehensive test ban. Eisenhower was not initially well acquainted with Strauss, but the AEC chairman shrewdly ingratiated himself with the president. Moreover, in controlling most of the scientific advice designed to reach Eisenhower, he effectively skewed the arguments in favor of continued testing. He also mostly deflected the 
criticisms of testing advanced by Thomas Murray, an AEC commissioner, and Harold Stassen, Eisenhower's erratic disarmament adviser. Strauss's actions were not simply a power grab but a reflection of his extreme views of the Soviets as "cold blooded murderers" (31).

Another strength of the book is Greene's careful elucidation of the incremental steps leading to the Eisenhower administration's pursuit of a test ban. One was the mounting international public opinion against testing, which was fueled by concerns over the deleterious health effects of fallout. The emphasis on a test ban by the Democratic Party challenger, Adlai Stevenson, in the 1956 election campaign was another. And the Soviet launch of Sputnik nearly a year later prompted Eisenhower to appoint a personal science adviser and a Presidential Science Advisory Committee, which included many scientists who favored a test ban. Eisenhower soon announced a test moratorium that lasted for two years and entered into serious negotiations with the Soviet Union for a comprehensive agreement.

Obviously sympathetic to Eisenhower's sustained efforts, the author stresses the determined opponents of arms control and the scientific and technical complexities of monitoring and inspection, which were beyond the president's understanding, as major factors in failing to reach a test ban with the Soviet Union. But he is not uncritical and concludes, for example, that Eisenhower "could not have picked a worse person" than Strauss and that he "erred miserably" in his appointment of Stassen $(50,80)$.

In the end, the entire test ban debate has an aura of unreality about it. Eisenhower's advisers often argued that a test ban with the Soviet Union would freeze the U.S. advantage in nuclear weapons, but it was unlikely that the Soviet leadership would have accepted any agreement that did not permit them to strive for nuclear parity. The test ban agreement negotiated by the Kennedy administration in 1963 covered only atmospheric tests, and Greene mentions only in passing that underground testing thereafter accelerated. Moreover, readers should be forewarned that the author's self-imposed, restrictive focus on the testing issue necessarily slights other important factors. World opinion also reacted negatively to other elements escalating the arms race, including rising nuclear stockpiles and the emplacement of U.S. nuclear missiles in NATO countries. And on the arms control side, test ban talks were only one of several Eisenhower confidencebuilding initiatives to revive a U.S.-Soviet dialogue that offered possibilities for major détente in the future. 
Daily Lives of Civilians in Wartime Early America: From the Colonial Era to the Civil War. Edited by David S. Heidler and Jeanne T. Heidler. (Westport, Conn.: Greenwood Press, 2007. Pp. xx, 248. \$65.00.)

This anthology of six chapters on civilian experiences in early American wars favors the nineteenth century. Common themes include how wars blurred the lines between civilians and combatants; how the militia and military were drawn from civilian populations; and how civilians provided food and supplies to the armies and experienced shortages, economic crises, violence, and displacement. The essays cover the colonial period, the American Revolution, the War of 1812, the Mexican War, and the final two chapters focus on the Civil War.

Armstrong Starkey's "Wartime Colonial America" surveys the differing European and Native American approaches to war and the lack of distinction between combatants and noncombatants. The decision, whether authorial or editorial, to treat all colonial wars in one chapter is unfortunate and inconsistent; the result is an overview of events, whereas all other chapters center on one conflict and consequently treat it in detail. Wayne E. Lee's “The American Revolution” depicts the war as "a kind of lurking shadow" and thereby underscores its unpredictability and civilian vulnerability to demands of military service; to the impressment or confiscation of property; or to violence, disease, inflation, and shortages (62). This balanced essay considers multiple perspectives and clearly assesses problems of choosing sides and recruitment. “America's War of 1812 ” by Richard V. Barbuto is comprehensive in its descriptions of American society and sensitive to regional differences in the waging of the war, balancing tales of the burning of Washington, D.C., and York in Upper Canada and noting that, in the central theater, the war "was hard on civilians, soldiers, and natives alike" (99). Gregory Hospodor's "The American Home Front in the Mexican War" argues that most Americans "experienced the war vicariously" through a print media that portrayed it romantically and heroically (115). This "vicarious war" fit well with the Revolutionary heritage, and so, despite some Whig and nonpolitical dissent, most Americans supported the war, which in turn prepared a generation to do battle in 1861 .

The final two chapters on the Confederate and Northern home fronts, by James Marten and Paul A. Cimbala, respectively, are each effective, wide-ranging summaries of topics with voluminous secondary literature. Marten shows the war's many effects on the economy and society (enormous inflation, food shortages, conversion to war economy, and women's roles) and its challenges to the founding assumptions of the Confederacy, from states' rights to slavery. The high rate of military mobilization meant that the lives of everyone left at home were "changed 
dramatically" (157). Cimbala's chapter on the North examines the progression of civilian opinion on the war, from Fort Sumter to war mobilization and later celebrations at war's end, mourning for Lincoln, and demobilization. It clearly portrays the effect on the economy, women, and African Americans and how the previously distant national government became a more intrusive presence as the war "reached into all corners of northern life" (224).

Although some variation exists in the quality of the essays and, more significantly, the degree to which they focus deliberately on civilians or integrate women's experiences, as an overview of an important problem, this helpful volume contains a few analytical gems and some useful syntheses.

University of Western Ontario

Nancy L. Rhoden

Gender, Religion, and Radicalism in the Long Eighteenth Century: The "Ingenious Quaker" and Her Connections. By Judith Jennings. (Burlington, Vt.: Ashgate Publishing, 2006. Pp. viii, 196. \$99.95.)

The Quaker artist Mary Knowles is perhaps best known to literary scholars today for her famous debate over women's liberty and religion with Samuel Johnson, dutifully (if inaccurately) recorded in Boswell's Life of Johnson, while art historians laud her exquisite needlework portrait of George III. As Judith Jennings persuasively argues, neither of these descriptions captures the depth of Knowles's engagement with a host of crucial issues circulating in late-eighteenth-century Britain: a lacuna that this biographical study aims to fill.

In her well-researched analysis, Jennings not only highlights Knowles's contributions to British (and Atlantic) culture, but also uses her life as a point of departure to explore broader issues relating to gender, religion, and politics. As a frequent visitor to the literary salons of London, and one who also had political influence with the royal family and leading Quakers, Knowles was particularly well connected. This contextual study of her experiences allows Jennings to explore a number of the controversial issues that faced British society during this period.

As Jennings explains, Knowles used three methods to advance her beliefs. The first of these was her pioneering use of needlework to create portraits of herself and the royal family. In doing so, Knowles challenged contemporary Quaker attitudes toward portraiture as well as accepted conventions of female artistic production, as she stitched these images at a time when such actions undertaken by a woman "constituted a radical act of self-representation" (172). 
In a similar manner, Knowles circulated a number of her manuscripts on the nature of Quaker belief and political rights among her friends. According to Jennings, the widespread dissemination of her ideas constituted a "social text, serving an intermediate function between public and private" that allowed her to challenge prevailing orthodoxies while still remaining within the sphere of public engagement afforded to women (15).

Knowles was also personally involved with many prominent Britons and socially "embraced new forms of polite Quakerliness" that allowed her to advance contentious positions, such as her criticism of slavery and sympathy for the American and French revolutionaries, while simultaneously affirming her religious belief and dedication to the national interest (73). In doing so, Knowles became one of the foremost defenders of Quakers in a culture that increasingly questioned their patriotism and religious conviction. As Jennings ably argues, this position of prominence, as a Quaker woman known for advancing radical political positions, caused problems for Knowles and shaped her reputation to the present day, most noticeably in Boswell's misleading account of her argument with Johnson. In this interesting study, Jennings has not only clarified Knowles's place in literary history, but has also provided a welcome contextual examination of the roles played by gender, religion, and politics during the latter half of the eighteenth century.

University of South Dakota

Scott Breuninger

Hunger for the Wild: America's Obsession with the Untamed West. By Michael L. Johnson. (Lawrence, Kans.: University Press of Kansas, 2007. Pp. xviii, 533. \$34.95.)

How the American West came to be known as "wild" is the central question the author of this book sets out to explore. More importantly, what social, economic, political, and environmental impacts have notions of wildness had on the West over time? As this sweeping volume reveals, there are no easy answers to these questions. Michael L. Johnson's study of wildness is complicated, nuanced, messy, and filled with contradictions; it ultimately forces the reader to confront the ugliness of what Johnson calls "the destructive ambivalence of the Western wild-tame dialectic" (400). In that dialectic, Euro-Americans perceived themselves as adventurers seeking the wild. At the same time, they variously attempted to settle, civilize, suburbanize, and package that wild into something more domesticated-or even culturally chic.

In roughly chronological fashion, Johnson investigates thoughts about wildness from the prehuman West to the present in five far-reaching parts. In each part, 
Johnson focuses on the history of ideas, but most importantly on how those ideas intersected with and impacted American culture. He paints with a broad brush and touches the full range of wildness, giving significant attention in each part to changing perceptions of Native Americans over time.

The breadth and depth of Johnson's sources and topics are remarkable. This is a valuable synthesis of the most recent scholarship about nature and the Western environment, but it is ultimately far more than that. Johnson analyzes Western paintings, photographs, artists, writers, movies, literature, rodeos, dude ranches, dams, bombs, and cowgirls. Western personalities such as Daniel Boone, Davy Crockett, and Buffalo Bill Cody do not escape his gaze and neither do "poisoned places" and urban spaces (298). As a result, he conveys a strong sense of the cultural weight that ideas about "wildness" have placed on the back of the West, a burden that the region continues to bear as Americans commodify Indians, "Disneyfy" the frontier, and "Ralph Laurenize" its range lands $(311,323)$.

The breadth of Johnson's study, however, sometimes limits his attention to details. He suggests, for example, that Mormons resisted "instant communication" in the form of telegraph lines, when in fact they petitioned Congress to connect Utah with the outside world and later helped to construct the transcontinental telegraph (176). Some might also question Johnson's description of the "closing of the frontier" as an "event," especially in light of his reliance on Patricia Nelson Limerick's work throughout the volume (187).

In the end, Johnson wants his readers not only to understand the problems associated with America's ambivalence toward wilderness, but also to do something about it, "to reach an atonement of nature and culture, savage and civilized," to "learn to live in and steward the real West," to transform society "to match the scenery," and to implement a "doctrine of wise nonuse" (400, 389, $323,350)$. Even though the practical applications of these suggestions are left to the reader, Johnson creates a rich and deeply textured space for a variety of thoughtful conversations and actions to begin. This is a landmark study that deserves a wide audience, especially among students of American studies, the environment, and the West.

University of Utah

W. Paul Reeve

From Snake Oil to Medicine: Pioneering Public Health. By R. Alton Lee. (Westport, Conn.: Praeger, 2007. Pp. 233. \$49.95.)

This is the fascinating story of a largely forgotten individual, Dr. Samuel J. Crumbine. That he has been largely forgotten is a shame because in his day 
Crumbine was a "mover and shaker" in the field of public health. Public health is characterized in this study by both the older and newer definitions: "[C]ommunity action to avoid disease or other threat to health and that public health policy should actively promote health, not just maintain it" (ix).

The author, R. Alton Lee, spent years tracking down his subject. Born in September 1862 during the Civil War, Crumbine lived until 1954, his life spanning an amazing amount of medical and public history. His is almost the all-American success story. Born in a log cabin, he grew up in humble circumstances after his father died in Libby Prison. Working his way through life from a very young age, Crumbine started as a druggist in Spearville, Kansas; after graduating from medical school, he opened his medical practice in Dodge City. He then spent his most fruitful years in Kansas as a physician and advocate for public health. He gave up practicing medicine in 1907 and devoted himself to public health issues in a variety of ways. Eventually, he moved to New York City and continued his efforts from there.

Chapter one, "The Wild West," gives the reader a good idea of the medical situation in Kansas and small-town America. It was not a pretty picture, and, no doubt from his experiences there, Crumbine became well aware of the need for education about and improvements in public health. The reader unfamiliar with medical practices and health issues of the late nineteenth century will be in for a revealing read.

The next chapter dealing with "Promoting Public Health" may turn a few stomachs. It provides excellent insights into the man and the issues and causes for which he fought as well as those he opposed. There was hardly a health issue he did not tackle. Crumbine had a flair for slogans-"Swat the Fly" along with "Bat the Rat" - that worked and brought him into national attention.

There is no doubt what the author set out to do: rescue his subject. As Lee writes, "[Crumbine's] great achievements deserve the same recognition today that they received during his lifetime" (195). This volume merits a large audience for its revealing insights into a variety of medical topics and public health issues. The chapters are long and the writing stately, if not sprightly, but the reader needs to continue on for the insights to be gained.

Crumbine deserves the overdue recognition that the author gives him. Beyond that, though, Lee presents an America that is long gone, and a man who helped change it through his work in public health.

Fort Lewis College

Duane A. Smith 
Dry Manhattan: Prohibition in New York City. By Michael A. Lerner. (Cambridge, Mass.: Harvard University Press, 2007. Pp. 351. \$28.95.)

When was the last time a new book was better than its publisher's claims? The dust jacket of Dry Manhattan asserts that the book is "the first major work on Prohibition in nearly a quarter of a century," raising doubts as to whether the author or publisher paid any attention to a steady stream of important scholarship since the early 1980s. Michael A. Lerner has, however, made use of Richard Hamm's Shaping the Eighteenth Amendment, Catherine Murdock's Domesticating Drink, and other recent contributions. Lowering expectations seems like a dubious marketing strategy for an engaging book on an important topic.

As the nation's greatest metropolis, and with its largest concentration of recent immigrants, New York City in the 1920s represented one pole in the conflict over alcohol use in the United States. Lerner is at his best describing the city's early reaction to the imposition of wartime Prohibition and then the Eighteenth Amendment to the Constitution in January 1920. New Yorkers were unable to accept, perhaps even to fathom, the extent of the national consensus necessary to amend the Constitution. Just because more than two-thirds of Congress and three-fourths of the states had approved the addition to the nation's basic law did not mean that Big Apple dwellers were willing to embrace it. From the moment that the Volstead Enforcement Act began to function, an untold number exploited its loopholes allowing home brewing, winemaking, and distilling for personal consumption as well as medicinal and sacramental use of alcohol. Other New York residents and visitors defied the law outright. Lerner argues that speakeasies, nightclubs, and jazz joints from the Bowery to Harlem defined the character of the city throughout the 1920s. His vivid and detailed description of this culture and the failure of efforts to enforce the liquor ban in Manhattan and the other boroughs seems well researched, though a tenfold exaggeration of the cost of a police raid and the number of delegates to the 1932 Democratic Convention raises doubts about other quantitative claims.

The greatest test for locally focused historians can be relating the peculiarities of a particular place to broader circumstances. Comparing conditions in New York to those nationwide is a challenge, whether the issue is the degree of conformity with the law (much higher outside of central cities), the nature of the illegal liquor trade (more centrally controlled in cities such as Chicago, and thus comparatively less competitive and violent), or the nature and pace of political change. What Lerner sees as a fairly simple story of steadily growing support for Prohibition repeal led by prominent New Yorkers such as governor and 1928 
presidential candidate Alfred E. Smith, Pauline Sabin of the Women's Organization for National Prohibition Reform, and Franklin Roosevelt was indeed far more complicated. The almost total national reversal from 1919 to 1933 required to obtain congressional and state ratification majorities to overturn the Prohibition amendment involved enlisting support from many who loathed New York and distanced themselves from all it symbolized.

Northern Illinois University

David E. Kyvig

The Politics of War: Race, Class, and Conflict in Revolutionary Virginia. By Michael A. McDonnell. (Chapel Hill, N.C.: University of North Carolina Press, 2007. Pp. 568. \$45.00.)

When an author admits that what he has uncovered in the archives was "something of a surprise to [him]," chances are what follows will be promising (2). This certainly holds true for Michael A. McDonnell's masterful new book. In The Politics of War, McDonnell argues that historians have misread Virginia during the Revolutionary War. According to McDonnell, Virginia hardly followed the lead of Washington, Jefferson, Henry, and Madison into independence unanimously; the Old Dominion was instead riven with conflict, both between blacks and whites and within white society. McDonnell investigates the effectiveness of mobilization, especially militia turnout and responses to the draft, to reveal a Virginia much less at the forefront of American patriotism than previously assumed. He argues that this conflict matters because the pressures brought to bear by ordinary Virginians "transformed the War for Independence into a Revolutionary War, fundamentally changing the course of their history and the new nation they created, for better and for worse" (15).

The conflict between Virginia's blacks and whites during the Revolutionary War has become fairly familiar territory of late; recent works by Simon Schama and Cassandra Pybus also detail persistent slave resistance throughout Virginia's war. What is new in this work, however, is the meticulous presentation of class conflicts that shaped Virginia's response to several critical wartime issues, including how many soldiers it sent to the Continental Army, how well it was able to defend itself, and the postwar legitimacy of local, state, and national political authority. McDonnell's findings are indeed unexpected: low turnout for militia musters, sometimes violent resistance to draft orders, and alarming disaffection to the "common cause." His chapter on Yorktown-which is provocatively entitled "Defeat"- -shows just how few Virginians helped defend their own home state: out of a potential militia force of 50,000, "perhaps no more than 3,000 partici- 
pated in some way" in the 1781 siege, a fraction that approximates the number of enslaved Virginians who sought refuge behind British lines (474).

The author makes an important historiographic contribution in part because he challenges one of the most compelling and enduring works on eighteenthcentury Virginia, Edmund Morgan's American Slavery, American Freedom [1975], which argued that Virginians turned to slavery and a racial divide as an alternative to class conflict. But McDonnell unearthed plenty of class discontent in the Old Dominion. Understanding these class divisions, he argues, changes the way historians comprehend Virginia's entire war experience, including the context of how Virginians reacted to slave resistance throughout the conflict. This fuller context gives his explanation of the response to Lord Dunmore's 1775 emancipation proclamation, for example, more weight than previous accounts.

The result of this two-pronged resistance, he concludes, was a drastically different political landscape than that envisioned by the planter elite. Chastened patriot leaders grew rather discontented at the "fractious popular political culture that developed during the war" (526). According to McDonnell, this divisiveness had enormous consequences; he contends that this difficult experience of dealing with popular disaffection shaped Madison and the nationalists' increasing pessimism toward human nature, which emerged in the Constitution. Although McDonnell's "bottom-up" approach has its limitations-he does not fully explore how exactly Jefferson, Madison, or Washington envisioned Virginia's political future-nevertheless, The Politics of War is required reading for students of the American Revolution. Hopefully, McDonnell's surprise will encourage them to hit the archives as well.

College of William \& Mary

Robert G. Parkinson

Sherman's Forgotten General: Henry W. Slocum. By Brian C. Melton. (Columbia, Mo.: University of Missouri Press, 2007. Pp. xi, 292. \$44.95.)

Despite having risen to the command of the Army of Georgia, one of the two wings of William T. Sherman's forces that ravaged Georgia and the Carolinas during the last year of the American Civil War, Henry W. Slocum has elicited no modern biography prior to this volume. To a considerable degree, this vacuum is because there is no extant collection of Slocum papers. The author was forced to make do with two eulogies and a 1913 life-and-times hagiography by a family descendant, which were based in part on manuscripts that have since disappeared. Under the circumstances, Brian C. Melton has done a capable job, though Slocum's personality rarely shines through. 
Perhaps, in fact, Slocum lacked much personality; Melton argues that he was something of a chameleon: "Slocum would often unconsciously emulate the army commanders under whom he served" (59). While serving with George G. McClellan, Slocum was an excellent drillmaster who had "the slows" about engaging in battle. While with Joseph J. Hooker, he was wildly disputatious and unethical, several times stabbing his superior in the back in letters and meetings with President Abraham Lincoln. But then, during the last year of the war, he became efficient, ruthless, and destructive while serving under Sherman's command.

This final imitation of Sherman went even deeper than Melton appears to realize. While ravaging the Deep South, Slocum mocked "darkies," and he lusted for revenge in South Carolina. "She will pay a fearful price," he wrote, using not only the ideas but also the very language of the colorful Sherman (193). The Sherman impersonation continued after the war. Slocum returned to Syracuse, where he had been a small-time Republican, lawyer, and real estate mover and shaker before the war, only to endorse Andrew Johnson's anti-Radical Reconstruction position and run for Secretary of State of New York as a Democrat. Once more, his reactionary opinions paralleled those of Sherman, making it sensible for Melton to have extended his psychological analysis to the postwar period, which he failed to do.

Smeared and destroyed in the 1866 elections by his infuriated erstwhile Republican comrades, Slocum fled Syracuse, where he was persona non grata, for Brooklyn, where he became a local Democratic wheel horse and grew wealthy in the streetcar business. No doubt he was aided in business ventures by inside information from the local political machine. There is, of course, no written record of such transactions.

Unlike many other biographers of second-rank characters, Melton does not try to make too much of his subject, although he does engage in some special pleading for Slocum at Gettysburg. Most previous authors have concluded that Slocum was almost cowardly in his refusal to engage in battle on 1 July, while Melton chalks the hesitation up to unclear orders from headquarters and the general confusion of battle, especially on that chaotic first day.

In the end, this controversy over Gettysburg is a quibble for the buffs. In general, Melton has succeeded in rescuing Slocum from obscurity, even if his shadowy subject appears to have lacked much in the way of a clear and independent identity. 
Becoming Free in the Cotton South. By Susan Eva O'Donovan. (Cambridge, Mass.: Harvard University Press, 2007. Pp. xii, 355. \$35.00.)

Like many scholars who have been involved with the Freedmen and Southern Society Project at the University of Maryland, Susan Eva O'Donovan writes about the transition from slavery to freedom. Her book is the latest in a series of such studies. O'Donovan's study, however, does manage to carve its own niche by looking at an area, southwest Georgia, where the impact of the Civil War was not so dramatic and where Reconstruction was relatively short-lived. She is then able to point to many more continuities between the eras of slavery and emancipation and the importance of the legacy of slavery than many scholars who write on this subject. Moreover, by insisting on gendering her story of slavery and freedom, O'Donovan attempts to add further nuance to a familiar narrative.

Although the broad outlines of O'Donovan's discussion of the nature of slavery in southwest Georgia, including her distinction of the worlds and work of female and male slaves, will be familiar to most historians of slavery, her pointed descriptions of the hard driving and brutal nature of slaveholders in the cotton South are both original and refreshing. She spends much time describing the labor regimen of this area, with slaveholders and planters bent on eking out every last bit of labor that they could get from their enslaved labor force. Though O'Donovan unfortunately does not explicitly argue this, her description of slaveholders who extended the workday, took away the traditional weekend respite from labor from slaves, and hired and sold their slaves without compunction seriously challenges the idea of slaveholder paternalism portrayed so forcefully by Eugene Genovese decades ago. Slaves, on the other hand, recovered the best they could from the tragedy of the interstate slave trade and built families, communities, and churches to withstand this onslaught on their persons and time. Slave women, she contends, were especially influential in constructing the spiritual lives of their communities.

Most of the book is devoted to recounting the arrival of emancipation in this corner of Georgia. The author makes a strong case for continuity for an area that was removed from the major theatres of warfare and that did not experience a wholesale defection of slaves to Union army lines as in Confederate areas that were in close proximity to them. Instead, other planters "refugeed" their slaves here. But even in southwest Georgia, as O'Donovan concedes, the end of the war made slave men and women challenge their enslavement through disobedience, dawdling, and outright defiance of their masters. 
During the short-lived years of radical Reconstruction, freed people sought desperately to gain control of their lives and labor by making use of sympathetic federal officials from the Freedmen's Bureau and joining the Georgia Equal Rights Association, the Republican Party, and Union clubs. In an effective chapter on the gendered dimension of emancipation, O'Donovan shows how black women, especially those with young children and without male relatives, bore the brunt of planters' callous and cruel attempts to regain control over the emancipated slaves. The overthrow of Reconstruction and the planters' campaign of terror and intimidation would ultimately blast black hopes for citizenship and control over their labor.

This highly readable book elegantly recounts the tragedy of slavery and emancipation even though many of its conclusions will be familiar to experts in the field.

University of Massachusetts, Amberst

Manisha Sinha

John Kenneth Galbraith: His Life, His Politics, His Economics. By Richard Parker. (Chicago, Ill.: The University of Chicago Press, 2005. Pp. 820. \$22.50.)

In the interest of scope and accuracy, this author could easily have borrowed the title of Galbraith's 1994 memoir, A Journey Through Economic Time, for he takes the reader through the leading economic events, schools of thought, and controversies of the twentieth century. This is not merely the biography of a professor who taught at Harvard for three decades and became one of the nation's most noted economists and public intellectuals. The work is no less than the intellectual history of economics from the disintegration of orthodoxy during the Great Depression to the rise and fall of the Keynesian alternative. The book is a wellwritten, even indispensable, guide to the intellectual controversies that marked the discipline of economics over the past one hundred years.

Galbraith's origins and early education provide few clues to his prominence. Born in 1908 into a middle-class farm family of Scottish origin in southern Ontario, he attended public schools and an agricultural college before earning a Ph.D. at the University of California-Berkeley in 1934. Galbraith's specialty, agricultural economics, won him an instructor's position at Harvard, the patronage of senior professors, and the opportunity to spend a year at Cambridge University, taking in the heady influence of John Maynard Keynes and his General Theory. The inspiration of Keynes, his emphasis on "demand-side" economics, and a positive role for government left a permanent mark on Galbraith's thinking. 
After stints at Princeton, the Office of Price Administration during World War II, and Fortune magazine, Galbraith wrote the conclusions of the Strategic Bombing Survey that called into question the effectiveness the Allies' bombing campaign. He returned to Harvard in a tenure-track position, but not without his Keynesian views attracting opponents among senior faculty and the Harvard Overseers.

In 1958, Galbraith published The Affluent Society and was transformed virtually overnight into the academic world's equivalent of a rock star. Coining such terms as "conventional wisdom" and "countervailing power," Galbraith's book became a bestseller. His success distanced him from the presumably value-neutral world of professional economists but brought him closer to the locus of power within the Democratic Party. Richard Parker maintains that The Affluent Society and its predecessor, American Capitalism, retain their value in the twenty-first century as descriptions of a uniquely American consumer society and its history since the Great Depression.

The apex of Galbraith's fame and influence came through his close association with Senator, then President, John F. Kennedy. Parker's chapters on the late 1950s and early 1960s are perhaps the most compelling in the book. They are essential reading for understanding the economic policy debates in the Kennedy administration and complement the memoirs of other insiders, like Galbraith's friend Arthur Schlesinger Jr.'s One Thousand Days or Theodore Sorensen's Kennedy.

After Kennedy's death Galbraith's opposition to the war in Vietnam eventually caused a break with Lyndon Johnson and the loss of insider status, if not influence with the reading public. In 1967 The New Industrial State became a bestseller and inspired a debate on the interplay of economics, public policy, and the common good. The presidency of Richard Nixon brought his famous confession, "I am now a Keynesian in economics," and the breakup of the Keynesian consensus under the impact of the oil shocks to the American economy and "stagflation" for the remainder of the 1970s (488). Galbraith retired from Harvard in 1975 and continued to write on economics and public policy, now as an outsider, especially in the Ronald Reagan and George H. W. Bush years.

Before his death in 2006, Galbraith cooperated with Parker in the writing of the biography by providing papers and manuscripts and was able to read the finished text. Some background in modern economics is essential for readers, but the biography belongs in the hands of scholars of postwar American political and economic history, graduate students, and college and university libraries. 
Partners in Command: George Marshall and Dwight Eisenhower in War and Peace. By Mark Perry. (New York, N.Y.: The Penguin Press, 2007. Pp. xvii, 472. \$29.95.)

This book is about the extended collaboration between Army Chief of Staff George Marshall and his lieutenant, Dwight Eisenhower. Mark Perry, a military, intelligence, and foreign policy analyst as well as the author of six previous works in these fields, argues that this relationship constituted "perhaps the most successful partnership in the history of modern warfare" (62). In a more muted statement of this thesis, Perry notes that "Eisenhower was an instrument of Marshall's commitment to building a global military coalition to face the Axis: he was the one senior officer who best understood its importance" (187).

After a brief summary of Marshall and Eisenhower's early careers, the story begins on 12 December 1941, when, at Marshall's behest, Walter "Beetle" Smith phoned Eisenhower, then in San Antonio, Texas, and instructed him to report to Washington to become the deputy to Leonard T. Gerow, Chief of the War Plans Division, the nerve center of Marshall's command post for global warfare. The narrative from there is fairly straightforward: Marshall tested Eisenhower by giving him a series of important and difficult assignments; Eisenhower passed each test; and Marshall moved Eisenhower steadily up the ladder of command, culminating in his chief lieutenant's appointment as the commander for the Normandy invasion and follow-on operations leading to defeat of the German armed forces. Throughout this period, Marshall and Eisenhower adhered to the intellectual legacy bequeathed to them by General Fox Conner: fight only when you have to, fight with allies, and keep America's wars as short as possible. After World War II, they extended this legacy by creating NATO as a strategic instrument for deterring war.

The book has much to commend it. At a time in American history when it appears that there is not a good fit between the nation's military capabilities and its strategic necessities, it is comforting to reflect on the work of two extraordinary men who saw both the political and military aspects of the global situation writ large, crafted a strategy to deal with that situation, then implemented their strategy in the face of considerable obstacles. It is also engagingly composed and contains a number of important truths, the most notable of which is that the Marshall-Eisenhower collaboration was very significant to American victory in World War II.

But these strengths are offset by several shortcomings. The first is a tenuously supported argument that by October 1944 "the upperclassman [Marshall] has now given way to the lower classman [Eisenhower]" (327). The second is a 
number of minor factual errors. As one example, Eisenhower and Gerow were not classmates at the Army War College in 1927, but at the Command and General Staff School from 1925 to 1926 (11). Finally, despite some perceptive mining of the Eisenhower-Marshall correspondence, there is an overreliance on secondary sources.

In summary, Perry convinces the reader that the Marshall-Eisenhower relationship was instrumental in the American victory of World War II and provides a decent sketch of their relationship. But the portrait of that relationship has yet to be painted.

School of Advanced Air and Space Studies

Harold R. Winton

The Sausage Rebellion: Public Health, Private Enterprise, and Meat in Mexico City, 1890-1917. By Jeffrey M. Pilcher. (Albuquerque, N. Mex.: University of New Mexico Press, 2006. Pp. x, 245. \$29.95.)

This author is arguably the most prominent historian of Mexican food and an accomplished scholar of Mexico's popular culture. In a previous award-winning book, Jeffrey M. Pilcher traced the five-hundred-year formation of Mexico's imagined national identity through its cuisine. In The Sausage Rebellion, his focus narrows to what he calls the "dark underside of urban provisioning," specifically the problematic attempts to modernize the meat supply of Mexico City during the regime of liberal dictator Porfirio Diaz (1876-1910), and the collapse of these efforts during the Mexican Revolution (1910-1917) (ix). Even so, the author ranges broadly from the colonial municipal meat monopoly to the closing of the Mexico City slaughterhouse in 1992 by the neoliberal government of Carlos Salinas, which ultimately accomplished what earlier reformers could not, undermining traditional meat interests and imposing the consumption of aged meat slaughtered outside the city.

Like much good microhistory, the book unfolds around a variety of archetypal actors: the large merchants who controlled the importation of cattle into the city; the butchers who worked in the municipal slaughterhouse and smaller shops; the public officials who attempted to modernize colonial markets, regulate public health, and balance the interests of national and foreign elites; and the urban consumers who demanded affordable and freshly slaughtered meat.

The narrative centers on the efforts of the Diaz government to modernize the meat trade through public health regulations and the construction of a new, modern municipal slaughterhouse, opened in 1897 with disastrous results, soon to be rebuilt and controlled, with marginally better results, by northern magnate 
and government insider Alberto Terrazas. The climax of the Porfirian meat project is the inadvertent control of the slaughterhouse after 1908 by U.S. businessman John DeKay, in his attempt to monopolize the national meat supply and transform consumer tastes from freshly slaughtered to aged, refrigerated meats. The "Sausage Rebellion" of the title is the denouement of that effort in the face of DeKay's own financial problems; the political hurdles imposed by the Porfirian government and exacerbated after 1910; the nationalism of the revolution itself; and the local resistance of meat importers, butchers, and consumers. The result, a postrevolutionary restoration of control by local merchants and butchers and of a consumer culture of freshly slaughtered meat, remained intact for much of the twentieth century, refurbished by the rise of "a corporatist state that treated consumer issues as a source of political patronage, but one that had to be balanced against the interests of labor and capital" (183). Thus Pilcher argues convincingly that the Sausage Rebellion reflected the broader course of the Mexican Revolution.

The participation of consumers in the Sausage Rebellion is, understandably, the most elusive assertion of this otherwise carefully researched and well-written book. Unlike his wide-ranging first book on Mexican food, this study may be too focused and too loosely structured to appeal to undergraduates without a strong background in the period. Even so, it is a valuable contribution to the study of food production, consumption, investment, and public health in Mexico City that will appeal to a variety of graduate students and advanced scholars.

University of Puget Sound

John Lear

Civility of Politics in the Origins of the Argentine Nation: Sociabilities in Buenos Aires, 1829-1862. By Pilar González Bernaldo de Quirós. (Los Angeles, Calif.: UCLA Latin American Center Publications, 2006. Pp. xiv, 399. \$29.95.)

The author of this study regards the lingering influence of traditional political narratives of Argentina's difficult nineteenth century as both a problem and a challenge. In this book, she chooses to mix three methodologies in search of a clearer understanding of how Argentina emerged as a unified nation after 1862. First, using police records and press sources, she constructs a description of how individuals from all social classes came together in civic and social groups. Second, she applies what she labels "experimental cartography" to show graphically where and in what volume civic and social groups developed and waned. Third, 
she uses prosopography to outline where participants in these groups fit into wider society and how networks of families and neighbors, as well as employers and clients, shaped political participation. At the heart of this study is an analysis of "associative discourse."

The author states:

The idea and practice of civility, thus associated with the constitutive principle of the social and political bond, placed such practices at the heart of the process of constructing a national representation of the community of belonging. (6)

Associative activity connected political elites with the broader population. These elites created and used an "associationist discourse ... to conceptualize the social bond" (6). Further, the locations where this association took place represented for the elites "a form of civic pedagogy through which the citizen learned of the public sphere" (6). This discourse and the process of association were "transformative." The shifting nature of sociability helped create the civil and political practices that emerged after 1862 .

To understand this process and its definitive role in the creation of the Argentine nation, Pilar González Bernaldo de Quirós focuses on the places, institutions, and organizations in which this process took place. She challenges other researchers who noted a decline in civility in the wake of independence. Instead, she asserts that although the forms of association shifted, civil engagement between elites and commoners continued, and the discourse that would eventually define Argentina shifted to different spaces as the Juan Manuel de Rosas dictatorship formed, fell, and gave way to a new regime. This process produced continuities that helped the city's elite maintain its status as regimes changed.

The study disappoints in many respects. Many of the thirty-three maps, charts, graphs, and drawings included are poorly labeled and difficult to interpret. The text is a difficult read. Passive phrases hide both assertions and conclusions. As the author admits, her study leaves out the ambition and achievements of all but the privileged few of Argentina's capital. Her focus on collective targets, appropriate given her methodologies, will satisfy sociologists more than historians. The semantic frame that González Bernaldo creates defines for readers civic arenas where groups engage. Although this is conceptually intriguing, it does not tell readers enough about the interactions that took place within these spaces. 
Ethnicity [Vol. 6 of the Encyclopedia of Southern Culture, ed. Charles Reagan Wilson]. Edited by Celeste Ray. (Chapel Hill, N.C.: University of North Carolina Press, 2007. Pp. xviii, 276. \$33.95.)

The original, one-volume Encyclopedia of Southern Culture [1989] garnered much well-deserved praise. Celeste Ray's Ethnicity is the sixth volume of the second edition of what will eventually be a twenty-four volume work. Ray's book replaces the "Ethnic Life" section of the older work, and should go far to winning the New Encyclopedia of Southern Culture as many laurels as its predecessor.

Ray's work is a significant expansion and reworking of "Ethnic Life." The old version included a total of thirty brief entries on specific ethnic groups preceded by a bit under twenty pages of introductory material. Ethnicity covers eighty-eight ethnicities, placed in context by nearly one hundred pages of introduction. Moreover, as the editor notes, she has maintained few of the original entries, and even those that survived have been updated. Just as important, the contributors reflect current understandings of ethnicity as a construct.

Ray and her contributors have produced a work that is far more multicultural than its predecessor. The 1989 edition focused on Native Americans and "white" ethnicities. Only one entry addressed Asians. None examined African peoples. Ray has largely filled in these holes in coverage and improved what were already strong points, rendering the work more useful to scholars and more relevant to general audiences.

Of course, no work is without flaws. Ethnicity is lacking in a few areas. For example, its multicultural approach has led to some unintentional distortions of the Southern past. In the praiseworthy effort to be inclusive, the profound and foundational impact of early English settlers receives approximately the same attention as does the recent influx of Laotian Hmong. This might strike some readers as a bit odd.

At the other end of the spectrum, the treatment of some peoples remains surprisingly sparse. For example, though Gwendolyn Midlo Hall contributes a valuable section on African ethnicities to the introductory material, African peoples garner little attention in the body of the work. Only the Igbo and Yoruba have their own entries. Groups who arrived in larger numbers, such as inhabitants of the Kingdom of the Kongo, did not find a place in Ethnicity. The same was true of some people who were small in number but had a disproportionate cultural impact, as did the Fon-Ewe in the Mississippi Valley. Perhaps these apparent gaps in coverage will be remedied in a later volume, however. 
Any serious student of Southern history will want access to the New Encyclopedia of Southern Culture. Ray's work promises to be among its most commonly referenced volumes. It may not be perfect, but it is certainly important.

University of Louisiana, Monroe

Jeffrey E. Anderson

War and Society in the American Revolution: Mobilization and Home Fronts. John Resch and Walter Sargent, eds. (DeKalb, Ill.: Northern Illinois University Press, 2007. Pp. viii, 318. \$22.50.)

While America's founders enjoy remarkable popularity among the public, the Revolutionary War itself provokes less interest among scholars and general readers. This edited collection of ten essays exemplifies a new military history, which, according to the editors, "view[s] the Revolution as a total war that at some time during the eight-year conflict touched the lives of virtually all American families, slaves and free blacks, and Indian tribes" (vii).

The volume contains ten essays divided into two parts, a concise contextual introduction by John Shy, and a short concluding historiographical essay. The first part consists of five remarkably cohesive essays about mobilization and motivation of common soldiers. Three are set in New England, one is set in Virginia, and one addresses African American recruits. By and large, they employ the methods of the "new social history," constructing prosopographies from muster rolls, pension applications, and local records. Judith Van Buskirk ventures into more detailed biographical narrative in her fascinating study of African American enlistees.

In general, these authors find that, contrary to popular wisdom, the Revolution was not "a rich man's war and a poor man's fight" and that soldiers were relatively representative of society as a whole. All three New England essays suggest that recruitment continued to be successful in most areas well after the "rage militaire" of 1775 , at least through 1777 , after which it was cut off sharply. However, Michael McDonnell's essay suggests that recruiting never went particularly well in Virginia, even when the state came under attack in the latter stages of the war.

A second, less cohesive section is called "Communities." The first essay examines the persistence of both restraint and violence among the North Carolina militia. The second two essays focus on the politics and perils of alliances with Native Americans for the rebels, the Loyalists, and the Natives themselves. The final two essays examine the role of women who followed the armies and who were displaced by warfare. 
Taken together, these essays hint at two salient features of the new military history. First, and most obviously, the emphasis is clearly on those who have been neglected before now-backcountry militia men, African Americans, women, and Native Americans. Virtually none of the authors discusses the Continental Army in any detail.

Second, nearly all of the authors emphasize nonideological motivations for joining and remaining in the armed forces. Militia men joined for monetary gain or to protect their own towns when the enemy was near (except in the case of Virginia). African Americans joined either the rebels or the Loyalists after calculating how best to liberate themselves. Native Americans chose their alliances based on what was best for the long-term interests of their tribes. Perhaps the only actors whom these authors suggest made ideological choices were the Loyalists. In this regard they seem to have veered nearly 180 degrees away from the literature of the previous generation and also to have differentiated themselves from more ideologically oriented recent works on common soldiers by David Hacket Fischer and Alfred F. Young. As such, this volume will be of interest to scholars of early America, although students may be a bit daunted by the technical nature of many of the essays.

Morgan State University

Lawrence A. Peskin

Lincolnites and Rebels: A Divided Town in the American Civil War. By Robert Tracy McKenzie. (New York, N.Y.: Oxford University Press, 2007. Pp. viii, 306. \$35.00.)

This author's compelling portrait of Knoxville, Tennessee, during the Civil War is the very best sort of community study. Lincolnites and Rebels illuminates the issues that tore white Americans apart during the early 1860s, but allowed them to reunite at African Americans' expense following Appomattox. An "island of Unionism" in a Confederate state, Knoxville lends itself to this ambitious treatment (4). It was internally divided, experienced both Union and Confederate occupation, and produced a remarkable wealth of sources ranging from correspondence to claims commission reports.

Robert Tracy McKenzie opens his chronologically structured work before the war. Knoxville had once been home to abolitionism, but by the $1850 \mathrm{~s}$, most of the town's Whigs and Democrats were committed to preserving both slavery and the Union. In 1860, Knoxville threw its support to Tennessee's own Constitutional Unionist presidential candidate, John Bell. Although they supported slavery in the abstract, Bell's backers feared the ascent of a slaveholding "aristocracy," 
which they believed was hostile to the majority of Knox County's white households that could not even afford their own farm or shop (43).

McKenzie argues that as Tennessee contemplated secession during 1861, the meaning of loyalty shifted. Knoxville residents no longer had to decide whether they were loyal to the Union, but rather whether they were loyal to their state and to the South. In February 1861, 89 percent of Knox County voters opposed even calling a convention to consider leaving the United States. In June, with Confederate militias concentrating in the area, Knoxvillians again voted against secession, but only by a narrow margin. Confederate authorities allowed Unionists to adopt effective neutrality. Most Union supporters refrained from acting against the Confederacy, although they continued to voice dissent. As was also true under the Union control after September 1863, local residents were the most eager to prosecute their neighbors—often old partisan rivals—for disloyalty.

Lincolnites and Rebels is not a thesis-driven book. Indeed, McKenzie demands that readers confront the ambiguities of wartime loyalty. Loyalty was not sustained, active, or unconditional. Many Unionists and Confederates defined it merely as the absence of overt opposition. The "temporal dynamic" of larger military and political events shaped locals' actions and attitudes (52). McKenzie also emphasizes the role of individuals. The "Fighting Parson," William Brownlow, provides the most important example. A former circuit rider and future governor, the Knoxville Unionist achieved national celebrity when he fled north.

The argument that white "Lincolnites" and "Rebels" had much in common runs through McKenzie's work. Both sides restrained violence against white civilians and shared a common antipathy to black rights. McKenzie ends with Unionists and Confederates lynching a black man in 1866, an action he argues "foreshadowed the basis for their genuine reconciliation" (223). Given this conclusion, Lincolnites and Rebels might have made more of Knoxville race relations during the war. Such ferocious racial violence requires more explication. Despite this quibble, McKenzie's nuanced monograph deserves wide attention from historians seeking to understand the meaning of loyalty in wartime and civilians' experience of the Civil War.

The Obio State University

Alison Clark Efford

The Rise and Fall of Indian Country, 1825-1855. By William E. Unrau. (Lawrence, Kans.: University Press of Kansas, 2007. Pp. xiv, 201. \$29.95.)

The 1830s, a decade of forced marches following passage of President Andrew Jackson's Removal Act of 1830, was not an auspicious time to be Native Ameri- 
can in the Mississippi Valley. Even legal actions promising protection, such as the Trade and Intercourse Act of 1834, came with a raw, ragged edge. As William E. Unrau's account in The Rise and Fall of Indian Country, 1825-1855 reveals, this act was less about protecting native interests than entraining Indian lands in the grand real estate agency that transferred title of large parts of them to the United States.

Native Americans have learned to be wary of bureaucrats bearing "gifts," whether they be half or a quarter section and a mule (allotment), boarding schools, or United States citizenship. Each was advertised as a ticket to a better life, but also demanded surrender of land, legal sovereignty, and ethnic identity. Couched in the language of assistance, each took more than it gave.

And so it was with the Trade and Intercourse Act of 1834, the last in a series of laws under that title beginning in 1790, initially intended to make transfers of land without federal government approval illegal. Several recent land claims (including one to a large part of the state of Maine) have been based on the 1790 act. By 1834, however, the name remained the same, but the substance of "trade and intercourse" had changed. During 1791, acting within the scope of the first Trade and Intercourse Act, Thomas Jefferson, as George Washington's Secretary of State, said that immigrants should be evicted by force from unceded Indian lands. By 1834, according to Unrau, the Trade and Intercourse Act was little more than a promise without substance, a deceptive stopgap that all but forced native peoples to exchange their productive homelands for removal destinations of dubious sustenance.

Unrau does his best to provide a native point of view of the events he describes, which is a very difficult task because nearly all the relevant historical records were maintained by a government in which native representation was all but nil. Nevertheless, he finds some gems, such as the Potawatomis' description of their assigned land as "a desert prairie [with] ... no timber, no sugar, no game, and in many parts no water. We could not get meat, no skins, no furs in that country" (11).

While the 1834 act was meant to protect native land holdings in a large area (north from Texas, nearly nine hundred miles to British North America, and west from the Mississippi River, excluding the states of Louisiana, Arkansas, and Missouri), the original promise of "lasting and undisturbed possession" proved fleeting (18). By 1846, a mere dozen years, the area was being severely eroded. Unrau provides a very detailed description of who lost what, to whom, and why, in a necessary corrective to scanty existing histories. 


\section{AsLA AND THE PACIFIC}

The Teeth and Claws of the Buddha: Monastic Warriors and Sōhei in Japanese History. By Mikael S. Adolphson. (Honolulu, Hawaii: University of Hawai'i Press, 2007. Pp. xviii, 212. \$36.00.)

The author pursues two issues in this book: "who the fighting servants of Buddha actually were, and why they remain such a visible part of Japanese culture even today" (3). The former concerns the origin and composition of what he terms jihei, or "temple warriors," and the latter concerns how monastic warriors became stereotyped as sōhei, or "monk warriors." In answering these two questions, one being "constructive" and the other being "deconstructive," Mikael S. Adolphson attempts to correct "a long history of distortion and prejudice against monastic warriors" $(5,6)$.

The strategy Adolphson uses to explore the two questions involves examining "the contexts in which religious institutions and their supporters, whether monks, menial workers, secular warriors, or any other group, used arms as a means to resolve conflicts" (20). This strategy, which Adolphson believes Japanese scholars have ignored, constitutes the main thread of his investigation, which involves a comparison between Japanese, Korean, and Chinese cases.

What Adolphson suggests is rather simple. By the late sixteenth century, the nature of skirmishes involving armed clerics had gone from isolated incidents to outright attacks to the widespread use of arms. Based on these changes, Adolphson concludes that, by the late sixteenth century, temple warriors had evolved into "a complex mix" that included monastic workers (dōsh $\bar{u})$, estate warriors, shrine members (jinnin), warrior managers, and even mystical mountain clerics (yama hosshi) (60). He posits this idea against those of Japanese historians, including Kuroda Toshio, who have insisted on "the addictive idea that monastic and secular warriors somehow belonged to separate categories" (84).

Adolphson slams what he sees as mediocre Japanese scholarship, which has created false images of monastic warriors, arguing that this work has relied "more on the constructs of the observer than on the societal circumstances in which those figures actually lived" (116-17). In particular, through his "deconstructive" analysis of stereotypical images of clerical skirmishes and Benkei, Adolphson tries to expose “[Japanese] scholars' failure to distinguish artistic representations from historical conditions, while ignoring the contradictory evidence in both the textual and visual sources" (120). 
In his attempt to correct the current misunderstanding regarding divergent monastic groups "who had the opportunity and ability to use arms to their own benefit," Adolphson highlights "the importance of historical context" $(156,161)$. It is a good attempt, but the context he identifies is nothing new; it is what students of medieval Japanese history already know full well. Historians of medieval Japan, including Japanese historians, have long studied Buddhist monks who were involved in politics, diplomacy, military operations, and trade (both domestic and international) in an age that saw "the increased tendency to settle disputes with the help of warriors" (157). But readers would look in vain to find their thoughts in The Teeth and Claws of the Buddha.

The University of British Columbia

Nam-lin Hur

Cult, Culture, and Authority: Princess Lieu Hanh in Vietnamese History. By Olga Dror. (Honolulu, Hawaii: University of Hawaii Press, 2007. Pp. 260. \$52.00.)

Popular religious practice in Vietnam has received significant attention from Western scholars in recent years, resulting in important studies by anthropologists Shaun Kingsley Malarney and Philip Taylor. ${ }^{1}$ Olga Dror contributes to this emerging field by complementing the anthropological perspectives and fieldworkoriented methodologies that inform works by Malarney and Taylor with a sophisticated historical and textual analysis of the diverse ways that Lieu Hanh cults have been understood, appropriated, and exploited by literate Viet elites over the last four centuries.

The author distinguishes between the "form" and "content" of Lieu Hanh's cult, the former referencing the popularly constructed worship that originated in northern Vietnam during the late sixteenth century and was primarily interested in the cult's perceived efficacy (Did the deity deliver?), and the latter indicating narratives invented by literati whose concerns were tangential to or unrelated to the cult's form. Dror analyzes previously undiscovered or insufficiently studied texts originally composed in Chinese or Vietnamese demotic script, beginning with the foundational work by Doan Thi Diem, an eighteenth-century figure considered one of Vietnam's most famous female writers. Her Story of the Van Cat Goddess, a fictional account based on the author's knowledge of the Lieu Hanh cult as well as her own life experience, although mainly written to express its author's personal

1. Shaun Kingsley Malarney, Culture, Ritual, and Revolution in Vietnam (New York, N.Y.: RoutledgeCruzon, 2002); Philip Taylor, Goddess on the Rise: Pilgrimage and Popular Religion in Vietnam (Honolulu, Hawaii: University of Hawaii Press, 2004). 
agenda—which was to criticize the treatment of women in her society—became a seminal work for those producing content to the Lieu Hanh cultic form, as subsequent authors reacted to her themes and/or exploited her materials. Among them was Kieu Oanh Mu, whom Dror describes as tormented by the threat of French-imposed colonial modernity, which he perceived as a threat not only to freedom but also to identity. His Translation of a Fairy's Record was thus an attempt at "self-preservation" of his people by reference to a secure position in the popular tradition from which they could address colonial-era changes.

Dror closes by sketching the changing treatment of popular cults by the states that have ruled Viet lands over the last four hundred years. Monarchical states of the precolonial period, she argues, feeling threatened by unpredictable local forms, suppressed or regulated them with but limited success, given insufficient bureaucratic means. The Democratic Republic of Vietnam and Socialist Republic of Vietnam, similarly threatened by cultic forms that they considered superstitious but with greater means at their disposal, brought public manifestations of cultic practices to a standstill during 1945-1986. The post-Socialist Vietnamese state (c. 1986-present), given the Soviet Union's collapse and facing integration into the international capitalist system, has followed a policy toward popular worship, which resembles that of the French colonial state from circa 1862-1941: permitting or encouraging popular forms redefined as "markers of national culture" (199).

This study will interest graduate students, scholars, and university teachers in history, anthropology, gender, religious, Asian, and Vietnamese studies; given its theoretical sophistication and depth of textual analysis, it is unsuitable for the undergraduate classroom.

University of Delaware

Mark W. McLeod

The Early Chinese Empires: Qin and Han. By Mark Edward Lewis. History of Imperial China, vol. 1, series edited by Timothy Brook. (Cambridge, Mass.: Harvard University Press, 2007. Pp. 321. \$29.95.)

Han China was roughly the equivalent in population, territory, and administrative sophistication to the Roman Empire. To provide a short, authoritative introduction to the period is a considerable challenge, but Mark Edward Lewis has succeeded admirably in his broad survey of Chinese history from $221 \mathrm{BC}$ to AD 220. Early Chinese Empires is a remarkable work of scholarly synthesis that covers not only politics at court, but also foreign relations, kinship ties, urban and 
rural life, religion, literature, and law. The volume is directed toward general readers, and as a result Lewis's explanations are clear and concise, with few references to academic debates or to detailed studies of earlier scholars. Nevertheless, Lewis is a master at this sort of presentation. He is adept at employing textual and archaeological evidence, and his writing is always engaging, even when he is explaining facts that will be familiar to many historians.

The difficulty in writing a book like this is identifying a few threads of causation that can account for a large portion of an otherwise unmanageable mass of data. Lewis's basic continuities, helpfully spelled out in his introduction, are five major features of the Qin and Han Empire: distinct regional cultures, the centrality of the emperor in the political structure, the cultivation of literacy, the demilitarization of the populace (with nomads being recruited into frontier armies), and the growing influence of powerful local families. To borrow an image from early Chinese literature, which distinguished between "classics" (jing) and "commentary," these five principles form the warp (also jing) on which Lewis weaves his depiction of life in the Han (209).

The steady flow of astute definitions, observations, distinctions, and connections (sometimes surprising ones) makes this book a delight to read. What follows is a sampling:

[T] he growing division between merchants and officials... replaced the ancient division between city dweller and rural populace as the central legal divide of the imperial period. (76)

[L]ocally powerful families did not shift toward a pattern of primogeniture in an effort to preserve their estates intact, preferring instead to maintain their position through increasing the number of their followers and dependants. (127)

[T] he Chinese world was marked by a contradictory set of equations in which power was located in the hidden depths of the interior [spaces], women were also located in the interior, but women were to be excluded from power. (165)

Chinese divination was usually regarded more as a guide to action than as the report of a fixed fate. (183)

"[By the period of $]$ the late Warring States the separation of the living and the dead had become a major aim of funerary ritual," in a shift from earlier ceremonies that had sought to connect people to their ancestors. (191) 
Early Chinese Empires is a brilliant example of nuanced, responsible popularization. As the first in a series of six volumes that will cover all of Imperial China, it sets a very high standard.

Essays in Frontier History: India, China and the Disputed Border. By Parshotam Mehra. (New Delhi, India: Oxford University Press, 2007. Pp. xi, 206. \$49.95.)

In 1962 India and the People's Republic of China (PRC) fought a bitter, brutal, and costly war along their Himalayan frontier. The war led to a fundamental transformation of India's defense policies, contributed to a major program of military modernization, and shattered long-held Indian hopes of amity with its behemoth northern neighbor. Since the late 1970s, India has made fitful attempts to improve relations with the PRC, and has made some progress. However, the core dispute related to the delineation of the Himalayan border still remains unresolved. Many rounds of high-level negotiations and bilateral discussions have only contributed to glacial progress.

The reasons for the lack of progress on this vexed border question are straightforward. India refuses to concede the territory that the PRC still claims in India's northeast. The PRC, for its part, is in no particular hurry to settle the dispute because it successfully managed during the 1962 war to seize some strategic territory that it had claimed in India's northwest. Control over this sliver of territory enabled it to link Tibet with Xinjiang province.

Scholarship on this dispute has been significantly stunted because of an acute paucity of access to the relevant archives. Both Indian and PRC archives remain closed, so scholars have been forced to peruse the occasional diplomatic or military memoir, scan newspaper reports, and make judgments on the basis of inference and attribution. Consequently, a great deal remains unknown about the postcolonial origins of the dispute, the bilateral discussions prior to the war, and the precise decisions on both sides (especially within the PRC) that led to the war. Worse still, the work of some analysts, most notably Neville Maxwell, on the origins of the war were quite partisan. Indeed, it was not until the publication of Steven Hoffman's India and the China Crisis that a dispassionate account of the border conflict became available. John Garner, another American political scientist, has chronicled the subsequent evolution of the border dispute and placed it within the overall context of Sino-Indian relations.

Parshotam Mehra, an Indian diplomatic historian of some repute, toiled hard in his earlier contributions to make some preliminary judgments about the origins 
of the border dispute through his work in the British colonial archives. This book, however, does not represent his best scholarship. Instead, it is a curious amalgam of past writings and bibliographic annotations on recent scholarship on SinoIndian relations cobbled together with a brief autobiographical introduction. Although there is some thematic coherence to the selection of his past writings and recent jottings, there is little or nothing that is new in this volume. Consequently, it does not add in any meaningful fashion to the existing corpus of scholarship on this important dispute between Asia's two emergent giants.

Indiana University, Bloomington

Sumit Ganguly

Behind the Mask: The Cultural Definition of the Legal Subject in Colonial Bengal (1715-1911). By Anindita Mukhopadhyay. (New Delhi, India: Oxford University Press, 2006. Pp. xiv, 301. \$39.95.)

Part legal history, part intellectual and cultural history, this book makes an important contribution to understanding the rule of law in colonial Bengal. Introduced by the British in the late eighteenth century, the rule of law was adopted and adapted by Bengali landholding elites and intelligentsia throughout the nineteenth and early twentieth centuries. Focusing on the historical shifts in understandings of legal subjectivity in colonial Bengal, Anindita Mukhopadhyay shows how upper-caste Bengalis, known as bhadralok, engaged with the idea of the rule of law. The first half of the book focuses on the shared interests between bhadralok and British rulers in affirming rule of law, while the second half turns to the ways that bhadralok increasingly began to challenge British governance by formulating new ideas of legal and moral subjectivity.

Mukhopadhyay argues that British rule of law was introduced on the presumption that all subjects were legally equal, whereas a caste-based social order in Bengal presumed that legal subjects were hierarchically ordered. Elite and uppercaste landholders assumed they were the ideal agents to spread the rule of law because they were rational, educated, civilized, while those on the bottom end of the social scale were inherently criminal. The bhadralok inserted themselves into a social hierarchy above the chotolok, or lesser peoples, who came to represent those who could never aspire to become ideal legal subjects because they were presumed to be habitual criminals. Mukhopadhyay reconstructs how Bengali landholders used the rule of law to further their own aims, simultaneously taking on the cloak of rule of law, while asserting their authority as being outside the jurisdiction of colonial courts by enforcing their own authority through their emissaries (38-44). 
Mukhopadhyay argues that Bengali elites had shared interests with the colonial government until the 1860s: bhadralok supported the colonial government in its efforts to put down the (tribal) Santal disturbances in the 1850s, and they also supported the colonial government during the 1857 mutiny. Yet by the indigo riots of the 1860s, when the colonial government supported European planters' interests over those of local peasants and landholders, Bengali bhadralok started to distinguish themselves from British legal and cultural practices. By the late nineteenth century, the idea of a new legal subject emerged for the Bengali middle classes, whose ambition was to challenge British rule through a distinctly indigenous sense of morality and justice that resisted "Western" forms of vice, such as drinking, gambling, and adultery (136-41, 217-25).

Mukhopadhyay's arguments are carefully constructed using a range of untapped materials in Bengali, including court records, novels, short stories, manifestoes, and vernacular newspapers. By the early 1900s, jail time became a source of pride for Indian nationalists, putting elites into physical proximity with their social inferiors. The author meticulously tracks the ways that Bengali discourses changed conceptions of legal subjectivity in the nineteenth century and raises an important question for understanding the issue of legal subjectivity in India now: What might be the postcolonial consequences of social hierarchies when they are embedded in the history of colonial rule of law?

Cornell University

Durba Ghosh

Empire, Identity, and India: Liberalism, Modernity and the Nation. By Peter Robb. (New Delhi, India: Oxford University Press, 2007. Pp. ix, 231. \$45.00.)

It is a measure of the maturity that the study of South Asia has attained over the last half century (and perhaps, too, of the aging of that international confraternity of scholars who wrought this renaissance) that publishers are starting to produce retrospective collections of work by some of these pioneering practitioners. For example, Oxford University Press New Delhi has recently gotten on the bandwagon with a new series called Oxford Collected Essays. The book under review, part of that series, showcases four fine articles by the eminent British historian Peter Robb originally published between 1991 and 1998.

For this reviewer, though, the most valuable part of the book is the discursive seventy-five-page introduction that forms part one of the book. Newly minted, this extended essay provides both an overarching framework for the articles that comprise part two and a vehicle for Robb to ponder some of the broad themes thrown up by these pieces and iterate his firm conviction that historians have 
undervalued the role of British colonial governance in the forging of the modern Indian nation. Although dismissive of the fashionable tendency to attribute the formation of communities entirely to the machinations of "instrumentalist" politicians, Robb accepts that identities are in part constructed, and he believes that colonialism played an important role in the constitution of modern Indian identities. "There were many superficialities and inadequacies in colonial rule, but it had a profound influence," because "the British tried to interpret and improve India" (9).

These days the British Raj is an unfashionable subject, "British policy" almost a "no-go" area for the younger generation of South Asian historians. As for the claim that colonial rule in India was informed by liberal values and (to some extent) good intentions, it will be anathema to many readers from the subcontinent. But Robb makes a persuasive pitch. Acknowledging that the British rulers of India were racist, ignorant, and often ineffectual, he insists, nevertheless, that their governance made a difference. The Raj was a new kind of government: equipped with the technological and bureaucratic capacity to reach down into society, obsessed with information gathering and categorization, and energized by the heady post-Enlightenment notion of limitless material progress. The resulting project, the "improvement" of India, was consequential, Robb avers, regardless of the fact that often things were not actually improved-for it raised Indian expectations about the possibility of individual mobility and the potentiality of government-driven social betterment, which turned it into "a project for the colonial ruler and subject alike," even if Indians had a different social agenda (65).

Some of Robb's speculations, for example, on the nationalist origins of Indian secularism, struck this reviewer as problematic. But the reviewer agrees wholeheartedly with the author's major contention-that the transformation of India in modern times cannot be explained independently of the power and policy of the Raj. Robb promises a second volume of essays on agrarian and legal themes. This reviewer looks forward to its appearance.

Monash University

Ian Copland

Empire, Identity, and India: Peasants, Political Economy and Law. By Peter Robb. (New Delhi, India: Oxford University Press, 2007. Pp. viii, 223. \$40.00.)

This is the second volume of a two-volume collection of previously published articles by Peter Robb, senior historian of India based at the School of Oriental and African Studies in London. The first volume (subtitled Liberalism, Modernity and the Nation) was published in 2006 . This volume is primarily concerned with 
the thorny relationship between colonial policy (and law) and agrarian change in nineteenth-century India. It has a long introduction, putting the question of British agrarian policy and its impact into its historiographical context. This is an excellent overview of changing British revenue policies and ideological assumptions relating to agrarian change in the nineteenth century, which, in turn, provides a framework for Robb's discussion of the relationship between policy and agrarian transformation or stasis. This is then followed in part two of the book by five of Robb's previously published (though somewhat revised) essays, covering the relationship of law and change, particularly as it relates to tenancy, commercialization, peasant stratification, and labor. Although Robb's arguments range over the broader literature on agrarian change in India, his major focus in all of his articles is on the Bengal presidency, and most specifically on Bihar.

Robb is a careful and meticulous historian who uses his research to challenge systematically many of the received assumptions about agrarian society and the impact of colonialism in India with which historians have long worked. His major concern, in fact, seems to be to steer a middle ground between those who argue for significant change in agrarian India as a product of British law and policy, and those who argue that changes under the British were superficial and that continuities arising from past relationships were far more important in shaping colonial society. Robb does not deny the central importance of new structures of state ideology and law under the British regime. Indeed, colonial policies, he argues, shifted over time and had a substantial impact on the way that agrarian relationships developed and were transformed. So did world capitalism. New legal structures were central to new conceptions of landed property in the nineteenth century and to new certainties about the meaning of "rights." Similarly, new notions of "development" played prominent roles in state policies toward the end of the nineteenth century. At the same time, as Robb carefully demonstrates, continuities from the past defined the frameworks in which all agrarian change was experienced. To assume any uniform impact of British policy, or of capitalism, on agrarian society would be a mistake. Whatever the changes promulgated by the British, in local society "interdependence and subordination wove a web in which agricultural decisions were caught” (138).

Robb's careful history is a powerful corrective to virtually all sweeping theories of agrarian change under colonialism. If there is any overriding message that his work carries, it is the overriding importance of the variability and complexity of agrarian relations in India. This is both the great strength and the weakness of this work. He provides a clear and powerful argument in favor of the importance of local detail and of skepticism in confronting large-scale teleo- 
logical models of change. Yet, his emphasis on complexity also makes it difficult to fit his work into the great historical debates that have obsessed historians of agrarian change.

North Carolina State University

David Gilmartin

Disciplining the State: Virtue, Violence, and State-Making in Modern China. By Patricia M. Thornton. (Cambridge, Mass.: Harvard University Asia Center, 2007. Pp. 247. \$39.95.)

The author of this book has selected three interesting moments in the history of state formation in China from the eighteenth century: the Qing government reforms during the Yong-Zheng reign [1723-1735], the Kuomintang's reforms during its decade of rule [1927-1937], and the Communist Party's socialist education movement [1962-1966] that preceded the more dramatic Cultural Revolution. The comparison of three important bursts of state activity, principally reform and extension of state power, may be explored from the perspective of several different problems. Patricia M. Thornton's principal goal is to probe the normative and moral dimensions of state making during each of the periods.

Simply put, Thornton argues that state building is a profoundly moral-or norm-creating-enterprise, which has been largely ignored in the history of Chinese state formation. In each of the three events, the author focuses on how representatives or agents from the central government sought to ensure the stabilization of the necessary and "proper" flow of resources from the locality through local reforms. The bulk of these reforms sought to ensure that local government agents became more reliable and susceptible to the goals of the central state. In a sense, Thornton's is a new take on an old problem in Chinese history: state-society relations.

Thornton utilizes a wealth of materials for her study, both primary and secondary. She has rich cases, especially from the Republican period, revealing how the state intervention often exacerbated the very problem it was designed to solve. She also engages a close reading of Wang Guangmei's (Liu Shaoqi's wife) analysis of the problems of corruption and insubordination of local cadres in her Taoyuan Brigade Report following the Great Leap Forward and the famine. Readers get a rare view of Wang and Liu's conception of the problem of local stratification that Mao would later attack and transform for his own political agenda. Indeed, Thornton also identifies important developments in all three cases. She shows how the initial effort to replace or reform local personnel met 
with resistance and came to be superseded by other agendas representing other interests within the central government.

The weakness of this otherwise engaging and useful book has to do precisely with the argument about normativity and morality. The moral argument is not always clear as Thornton chooses to identify different parts at different times. The cases also do not necessarily speak to the moral issues she identifies. As the reviewer understands it, she draws something from arguments about the "moral economy" of E. P. Thompson (not cited) and James Scott, especially in the Yong-Zheng case, to suggest that local officials siding with peasants against reforms were valorized by the local moral community (and thus how state intervention redefined the moral boundary between state and society). There is also a hint of this argument in the 1960s' events. At another level, she wants to use the arguments of Timothy Mitchell and Philip Abrams regarding the "state effect" or the "state idea"; but what exactly this "state effect" is doing in these campaigns is not entirely clear.

This conceptual weakness produces some missed opportunities. It would be most revealing to see some instances of the problem "of tailoring of projects in order to fit the normative language" (Quentin Skinner in Thornton, 205). With a little more work she could have also showed readers how the "mediation of penality [that] forms part of those mechanisms of domination" (Foucault in Thornton, 212) occurred in China. Finally, Thornton concludes with a discussion of the commercialization of the moral discourse of state corruption. Might the exploration of the different historical context of each period similarly yield a genealogy of state morality that could overwhelm continuities in the state society problem in China? Or can the historians' analyses of the continuity of institutional problems across three hundred years be sustained?

University of Chicago

Prasenjit Duara

\section{EUROPE}

Imperial Ideology and Political Thought in Byzantium, 1204-1330. By Dimiter Angelov. (Cambridge, England: Cambridge University Press, 2007. Pp. xx, 453. $\$ 110.00$.)

Quite correctly, the author of this book distinguishes imperial ideology from political thought. Especially in recent years, many historians have mistaken Byzantine panegyrics of emperors for serious political statements. Dimiter Angelov realizes that they were rhetorical exercises and scarcely even propaganda: "Imperial panegyric never had an extensive outreach as propaganda, because the speak- 
ers addressed an audience restricted to the court, used a difficult language, and preached a sermon to the converted, including the emperor himself" (180). Yet, after the humbling blow of the Crusader conquest of Constantinople in 1204, Byzantines did write other kinds of texts in which they frankly discussed the failings of their emperors and their empire, which struggled in exile as what we call the Empire of Nicaea, then recovered Constantinople in 1261, and was finally ruined by civil warfare and Turkish conquests.

A revised dissertation, Angelov's book has some faults typical of dissertations: unduly comprehensive treatment of the material (so that empty rhetoric receives almost as much attention as real thought), an arbitrary terminal date (which, fortunately, Angelov often disregards), and superficial references to earlier developments (e.g., stating that sixty-five Byzantine emperors were overthrown between 395 and 1453, when the actual number was about thirty-nine). Sometimes Angelov overrates his texts, especially the "mirrors of princes" (treatises on the ideal emperor) in which he finds a "spirit of realism and pragmatism" despite their insisting on no new taxes, no hoarding, no debt, and boundless generosity (195).

After overlong discussions of the panegyrics and mirrors of princes, the best part of the book begins midway, with discussions of political thinkers. These include the Nicene emperor Theodore II Lascaris [r. 1254-1258], who argued from Aristotle's Nicomachean Ethics that the emperor stood above the aristocracy, the law, and conventional morality. Angelov compares Lascaris to Machiavelli, but acknowledges that unlike Machiavelli, Lascaris "was not a fully secular thinker and was deeply affected by his faith and by Christian ideas" (252). Angelov also commends the historian George Pachymeres for his accurate criticism of corruption under Michael VIII [r. 1259-1282] and Andronicus II [r. 1282-1328], while conceding that Pachymeres's ideal that expenditures should exceed income "makes little practical sense" (275).

Turning to other Byzantine scholars, Angelov stresses how original Nicephorus Gregoras and George of Pelagonia were to criticize the principle of hereditary succession that produced contemporary emperors, and how innovative Nicephorus Blemmydes and Thomas Magistrus were to question the legitimacy of taxation, which Magistrus rejected outright. Manuel Moschopulus, revising traditional ideas under the influence of Plato's Republic and Western feudalism, maintained that emperors had obligations to their subjects, not just the other way around. Among churchmen who argued that the Church should be independent of imperial control, Bishop Macarius of Ancyra was astute enough to see that the Donation of Constantine was a forgery, while Patriarch Athanasius I declared that only the Church, not the empire, was an eternal and universal institution. 
Angelov presents a lucid, intelligent, and pioneering study of a time when Byzantine writers discarded ossified ideology to produce important political philosophy.

Saint Louis University

Warren Treadgold

The Cat and the Fiddle: Images of Musical Humour from the Middle Ages to Modern

Times. By Jeremy Barlow. (Oxford, England: The Bodleian Library, 2007. Pp. 88. $\$ 20.00$.)

Although scholars have studied specific sources or genres of music that contain humor (e.g., sheet music, minstrel shows, operettas, musical comedy), this book is the first modern effort to attempt an overview of the theme of graphic musical humor.

Beginning with the medieval period and extending to the twentieth century, Jeremy Barlow's research is based entirely on Bodleian Library collections that include manuscripts, prints, drawings, children's books, journals, sheet music, and ephemera produced primarily in England.

The first chapter examines religious medieval manuscripts, the marginalia of which includes such unlikely images as devils, anthropomorphic animals, and "mock instruments" such as bellows and tongs. In this chapter, and in the next one on secular romance manuscripts of the same period, Barlow asks whether these images were a reflection of reality—such as devils depicted in mystery plays or the "rough music" played in charivaris—or products of the imagination.

The third chapter addresses changes in graphic musical humor of the sixteenth and seventeenth centuries following the introduction of printing. The primary locus of imagery shifts to individually printed engravings, drawings, or paintings. These works frequently depict musical humor in scenes of carnival and the carnivalesque theatre that derives from Italian commedia dell 'arte. As Barlow shows in his next two chapters, prints of the seventeenth and eighteenth centuries also began using humor to comment on social life and class contrasts. Artists frequently used instruments associated with the lower classes (e.g., bagpipes or hurdy-gurdy) to make pointed comments about individual morals, society, and politics, especially through depictions of charivari and rough music.

Barlow's final three chapters address English satires on domestic amateur musicians from the late-eighteenth and early-nineteenth centuries, musical humor in children's books and musical oddities of the Victorian era, and music lovers in the twentieth century. He includes a useful glossary of obsolete musical instruments with references to the illustrations that depict them, a list of works con- 
sulted, and an index. The seventy-one pages of text include fifty-one beautifully reproduced illustrations, many in color, with accompanying explanatory captions.

Barlow's book is engaging, but as is indicated by its very short length, few citations, and bibliography of general surveys of humor and of music, it is not a scholarly examination of the subject. The text seldom provides analysis, and most chapters contain only about two full pages of text. In addition, Barlow frequently juxtaposes illustrations from widely diverse time periods in an effort to show that artists continued to use similar imagery, but he fails to recognize that the artistic intent differed greatly. For example, a fourteenth-century manuscript and a nineteenth-century caricature by James Gillray both depict dancing bears, but the meaning of these two images is strikingly different (22-23). One is a decoration possibly illustrating an event described in the manuscript, while the other is a commentary about the relationships of British politicians in 1806. Despite these shortcomings, this work serves to suggest a topic that deserves further serious study.

University of Southern Indiana

Tamara L. Hunt

The Dictatorship of Sex: Lifestyle Advice for the Soviet Masses. By Frances Lee Bernstein. (DeKalb, Ill.: Northern Illinois University Press, 2007. Pp. xvii, 246. \$42.00.)

The "sexual revolution" in Russia in the early twentieth century, by most accounts, reached its apogee in the wake of the 1917 revolution and its aftermath. Although hard, verifiable data are lacking, the available statistics and reports portray a major increase in premarital and extramarital sexuality, along with the emergence of a host of "deviant" forms of sexual behavior. All this became a major cause of concern for leading Bolsheviks, including Lenin himself, and encouraged the new regime to combat the licentiousness that seemed to cause the rise in prostitution, sexually transmitted diseases, and a host of other social ills.

This book examines the regime's partners in this campaign-those medical professionals who sought to communicate the new line on sexual behavior. For the most part trained under the ancient regime, they convened conferences, laid plans to conduct propaganda, and wrote the various texts for professionals and for the common people. The popular literature sought to exhort, admonish, and warn about the dangers of sexual excess and "deviant" behavior. This campaign commenced with the formation of the new regime and lasted until 1931, as the Great Turn took its toll. 
The author presents a systematic, comprehensive account of this sexual advisory literature, much of it rare and not easily accessed.

Brandeis University

Gregory Freeze

An Empire Divided: Religion, Republicanism, and the Making of French Colonialism, 1880-1914. By J. P. Daughton. (Oxford, England: Oxford University Press, 2006. Pp. xi, 330. \$55.00.)

A little more than a century after politicians of the Third Republic formally separated church and state, France today can seem as secular as any society that exists. The zeal with which the separation was defended, against a backdrop of emptying churches and an annual ordination rate for Catholic priests that struggles to exceed double digits, should not, however, lead historians to overlook the substantial imprint left by French religious workers on large parts of the world in the not-too-distant past. J. P. Daughton's excellent study, An Empire Divided, represents a much-needed corrective to an image that has gained wide currency among historians in recent years, whereby French colonial expansion and rule in the late-nineteenth and early-twentieth centuries appear to have been framed and executed according to some secular Republican master plan. But, as Daughton convincingly argues, a country that, in the second half of the nineteenth century, produced more Catholic missionaries than any other in the world, could scarcely establish its rule in new territories without taking account of and sometimes accommodating the religious expansion that accompanied the globalizing trends of the time.

After a valuable survey of French contributions to spreading the gospel before about 1880, Daughton presents case studies of three parts of the worldIndochina, Polynesia, and Madagascar-that fell under formal French control in the latter part of the nineteenth century. In diverse ways, these cases all illustrate one of Daughton's central points, that colonialism in different parts of the empire was shaped by conflict between missionaries and secular French antagonists in a time of mounting anticlericalism. These conflicts, as he shows, did not always unfold along the expected ideological lines, reminding readers that ideologies fashioned in Europe often had to adapt to local conditions in particular colonies. In Indochina, for example, an active contingent of anticlerical Freemasons accused Catholic missionaries of undermining France's "civilizing mission," such that the missionaries eventually realized they needed to emphasize their patriotism and their commitment to the work of empire in order to be allowed to continue their activities. In Madagascar, by contrast, the presence of British Protestant mission- 
aries, joined in 1896 by French Protestants, encouraged an unlikely entente between the colonial administration and Jesuits, as the latter's Catholicism allowed them to pose as more reliably "French" than Protestants.

The study of missions and the French Empire has long lagged well behind similar work by scholars of the British Empire. Daughton's energetically argued book, carefully researched on four continents, is a significant step toward narrowing this gap, and lays a solid foundation for further research. Readers will want to know more, for example, about the situation in territories with a Muslim majority, where a different kind of clericalism was in question, and about French missionaries in the period after World War I, which so far has received surprisingly little attention. What Daughton offers here, however, is already enough to force historians to think more deeply about the place of Christianity in the French colonial empire.

University of Delaware

Owen White

France after Revolution: Urban Life, Gender, and the New Social Order. By Denise Z. Davidson. (Cambridge, Mass.: Harvard University Press, 2007. Pp. v, 257. \$49.95.)

This author's meticulously researched account of urban life in Napoleonic and Restoration France efficiently demonstrates the complex way that gender and class interacted to produce the "new social order," in both public and private venues, of nineteenth-century France. Focusing her archival research in the provincial cities of Lyon and Nantes, Denise Z. Davidson makes excellent use of secondary literature to buttress and contextualize her discussion. Her focus on cities other than Paris enriches the scope of the study.

Davidson's overriding interest is in the way social order was reconstituted in the wake of the turbulent revolutionary decade, 1789-1799. In a world newly scoured of its previously entrenched hierarchies, the reestablishment of social order depended on drawing visible, consistent boundaries between "dangerous" and "bourgeois" classes. As Davidson shows, that task was effected through the management of public social life and made evident in no small part through the enactment of class-differentiated gender roles.

Through the constitution and policing of public spaces, such as official festivals, theaters, cafés, cercles, and salons, the new class topography was established and made intelligible. As Davidson recounts the process, the Napoleonic and Restoration public worlds were transitional in the emergence of distinctively classed forms of sociability. The early Empire saw the prevalence of mixed class "spectacles," a form of public life uncommon under the Restoration. Such public events included discrete but visible roles for notables and the working classes, 
both men and women. The Restoration, however, saw a palpable divergence in the geography of public life, breaking along class lines. Private bourgeois settings, increasingly male in character if not entirely sex segregated, emerged as central to social and political life. Whereas the Empire had evoked Revolutionary traditions while imposing authoritarian rule, the Restoration actively sought to disavow the Revolutionary decades. Thus under the Restoration, Davidson argues, incipient fears of the popular classes, reminders of the violence of the Revolution, came to be central to both bourgeois class identity and to the management of public space.

Davidson documents this transition through attention to the gendered dimension of class identity as it was displayed in public life. She shows the extent to which women's presence both symbolically civilized public spaces, such as theaters, and provided the justification for their policing along class lines. Davidson's work engages with an important historiographical conversation ongoing among women's and gender historians. To what extent, Davidson asks, does lived experience evince the "separate spheres" ideology long pondered by women's and gender historians? Davidson is not alone in asking this question, and she enters the discussion with persuasive evidence of women's active presence in French public life. In the provincial cities discussed here, women of all classes were both visible and active in the process, whereby new social hierarchies were defined, modeled, and experienced.

Davidson's contribution to the separate spheres conversation is ultimately a complicating one. Her work ably demonstrates the way that women could be both present and iconic; publicly displayed in a variety of settings, they were symbolically pivotal but politically, legally, and-to an increasing extent-socially disempowered as well. This iconic role for women would prove to be a double-edged sword throughout the rest of the century, limiting their entry into the role of active citizen. Thus, although women's demonstrated presence in public life undermines a literal interpretation of the "femme au foyer" ideal, it does not fully negate the underlying gendered assumptions through which the public world was constituted. This careful study will be of interest to historians of France, of gender, and of urban life.

Santa Clara University

Naomi J. Andrews

Gustav Mabler: A Life in Crisis. By Stuart Feder. (New Haven, Conn.: Yale University Press, 2004. Pp. viii, 253. \$39.95.)

The author of this biography is a clinical professor of psychiatry with a Freudian bent and a flair for reconstructing the psyches of historical figures, in particular of 
composers (an earlier book concerned the American composer Charles Ives). In his 1928 paper on Fyodor Dostoyevsky, Sigmund Freud wrote that "before the problem of the creative artist, analysis must, alas, lay down his arms," an admission that neither Freud nor his followers have ever taken seriously (cited on 242).

Indeed, as the example of Freud shows, creative geniuses have attracted considerable attention from psychological experts since the beginning of psychology as a branch of scientific inquiry. Some, like Kay Jamison, have been particularly drawn to the bipolar, manic-depressive model of creative genius (e.g., Robert Schumann), even going so far as to hint that all creative geniuses have been bipolar. Others, like the authors Stuart Feder and Maynard Solomon, or psychoanalyst Anna Burton, seem more drawn to the depressive, solitary types, like Ludwig van Beethoven, Johannes Brahms, or Gustav Mahler himself. The best of these works, with this book among them, have the capacity to deepen readers' appreciation of the artist and provide convincing explanations of both the course of their lives and the meaning of their works.

As Feder repeatedly emphasizes, Mahler self-consciously poured his life into his work, leaving Mahler scholars unlikely, perhaps, to commit the intentionist fallacy (i.e., attribution of intentions without supporting evidence), yet at the same time scrambling to reveal deep forces at work of which the composer himself was not aware. Developing just a few simple but resonant themes, chief among them Mahler's mother fixation and his "lifelong romance with death," Feder provides a satisfying, if slightly gossipy, review of Mahler's entire life. His account is accessible to the average reader yet at the same time filled with stimulating new insights for those already familiar with Mahler's life and work.

Not surprisingly, given the author's interests and expertise, the pivot around which this biography turns is the legendary four-hour consultation between a troubled Mahler and an accommodating Freud in the streets of Leiden on 25 August 1910. Mahler is the only enduringly famous composer whom Freud ever treated (if a four-hour conversation, with no follow-up, is a treatment), and later in his own life, with Mahler long dead, Freud was uncharacteristically forthcoming about what Mahler revealed and what he himself advised. Feder's book is worth reading simply for his two accounts of this meeting, a short one at the outset of the book, which hooks the reader, and a long, culturally contextualized one after Feder has told the whole story of Mahler's life up to this point, in 1910, less than a year before his death.

Feder emphasizes the dynamic of personal crisis and intense creative breakthrough in explaining the course of Mahler's life. He has consistently interesting things to say about how the personal crises-all ones to which mortal flesh is 
subject, including sibling and parental death, illness, pain, desire, and betrayalbecame embodied and thereby transformed in Mahler's music. Because of these personal travails-which Feder seems to suggest, unconvincingly, were worse than those of an average person-he diagnoses in Mahler an often acute anxiety about abandonment combined with a struggle to find transcendence of worldly pain. Mahler emerges from these pages a fully rounded human being, and if his music seems shadowy and insubstantial in contrast to the human drama that created it, then the reader must simply put the book down and return, with new insight, to listening to his music.

University of Rochester

Celia Applegate

Richard the Lionheart: King and Knight. By Jean Flori. Translated by Jean Birrell.

(Westport, Conn.: Praeger Publishers, 2006. Pp. x, 450. \$49.95.)

The romantic figure Richard the Lionheart is one of England's most recognizable monarchs. A courageous, daring, chivalric defender of the Christian church, the Richard of popular imagination emerges as the quintessential medieval knight. But is this characterization historically accurate? That is the subject of this groundbreaking book by prolific historian Jean Flori.

His study is divided into two parts, each with ten chapters. The first presents a biographical narrative of Richard as prince and king. Here readers learn how Prince Richard's seminal role in the pacification of Aquitaine (of which he was duke) earned him "a solid reputation as a valiant warrior" and the nickname "Lionheart" (42). Military successes continued after Richard became King of England. For example, he led a victorious assault on Messina, which "gave the chroniclers an opportunity to laud his knightly valour" (98). Richard, of course, is most remembered for his role in the Third Crusade, and Flori's examination of this subject is most significant. Convincingly, he argues that Richard's "relatively easy" conquest of Cyprus as well as his contribution to capturing Acre won for the king lavish praise from chroniclers $(113,118-128)$. Flori's critical reading of the sources also illustrates how chroniclers favorably interpreted the king's unpopular decision to abandon the proposed attempt to recover Jerusalem (152). In the last chapter, the author argues against the view that Richard died during the siege of Châlus because of some quest for treasure; rather, he died "as a prince seeking to enforce feudal order in his lands" (215). In the second and most engaging part of the book, Flori analyzes how and why Richard's chroniclers helped to turn this warrior-king into "a true model of chivalry" and determines whether or not Richard actually fit the bill $(12,240)$. The historical Richard who emerges here is 
misogynistic, anti-Semitic, and hedonistic - not exactly the model knight. How, then, does the reader reconcile the two diametrically opposed images? The argument advanced is that chroniclers (for the most part) not only glossed over, downplayed, or somehow justified qualities in Richard they found irritating but also emphasized, magnified, and embellished those qualities in him they found admirable (240). In the end, however, Richard's own actions and deeds provided chroniclers ample material with which to construct his image as a model knight. As is persuasively demonstrated, Richard "identified himself with chivalry and fully adopted and exalted its values.... In so doing, he created a new model of kingship, the archetype of the 'roi-chevalier'" (238).

This is an ambitious and meticulously documented work, and Flori makes deft use of a wide range of primary and secondary sources, including poetry, prose, romance literature, eyewitness accounts, letters, speeches, as well as an impressive array of contemporary chronicles written in English, French, and Arabic. This reviewer's only criticism relates to the overall structure of the work. A more cohesive book would have resulted had the author woven his latter analysis in with his former narrative. This easily could have been accomplished in those numerous places where Flori injects some version of the phrase "we will return in Part Two." Despite this minor criticism, the work is a welcome addition to the historiography not only of Richard the Lionheart, but also of the nature and development of medieval chivalry, knighthood, and kingship.

University of Tennessee at Chattanooga

Michelle White

Kristallnacht: Prelude to Destruction. By Martin Gilbert. (New York, N.Y.: HarperCollins, 2006. Pp. 314. \$21.95.)

Hershel Grynspan's assassination of a minor German diplomat in Paris sparked one of the plainest signals of the murderous intentions of Nazi anti-Semites. On the night of 9 November 1938, SA thugs and Hitler Youth stormed streets all over Germany and Austria, smashing and burning a thousand synagogues, destroying all identifiable Jewish businesses, looting Jewish homes, incarcerating one-fourth of the male Jewish population in camps, and beating and murdering ninety-one Jews, often in savage acts of brutality. The so-called "Night of Broken Glass" has been described in detail in many studies before now, but the noted author Sir Martin Gilbert has graced readers with a study that synthesizes what is known in a beautifully written and concise volume. Moreover, he has enriched readers' understanding by incorporating the recollections of some fifty eyewitnesses who 
recently recorded their terrifying observations and memories of that nightmare of their youth.

This is a personal tale for the author, himself a German Jewish refugee, and it is precisely that aspect-the personal details told by survivors-that sets this volume apart. Whether it is a childhood misunderstanding regarding the availability of money given for safekeeping to purchase a long-coveted item, or the hair-raising stories of German mothers lifting their children above the crowd to better view the beating and humiliation of hapless Jews, or the simple statement that a Jewish man was taken to the woods and used for target practice until he died, such details make what has often been a dry recounting of events and statistics both gripping and extremely painful. Although this study does not provide much detail from German documents to explain the planning and execution of Kristallnacht, eyewitness accounts afford a perspective and immediacy that few textbooks impart.

Gilbert carefully narrates the events that followed Kristallnacht to document the German and Austrian Jewish experience, whether it was incarceration and torture in concentration camps; Kindertransport to England; escape to other European countries, Shanghai, or the Western Hemisphere; expulsion to the killing fields of Eastern Europe; or deportation to the death factories of Poland. Familiar stories are embroidered with newly documented eyewitness accounts in a way that brings them to life.

Complemented by Gilbert's beautiful prose, this is a superb introduction to Kristallnacht and the entire history of the Holocaust inside the Reich. Fifteen maps of towns and cities where synagogues were incinerated, often while firefighters hosed down adjacent buildings, show the magnitude of the crime. A photograph of the shell of the Fasanenstrasse Synagogue in Berlin on 10 November 1938 bears eerie witness to the results. This study is an excellent introduction not only to the Night of Broken Glass, but also to the individual reality of the Holocaust. It is suitable for the general reader and the undergraduate student. But its haunting images will resonate with the Holocaust scholar as well.

Gallaudet University

Donna F. Ryan

What Was History?: The Art of History in Early Modern Europe. By Anthony Grafton. (New York, N.Y.: Cambridge University Press, 2007. Pp. 319. \$23.99.)

It goes without saying that historians are interested in knowing, remembering, and understanding the past. But only a distinctive few among them are also interested in the past of their own, namely the rise of historical study —and writing as a form of learning —and its transformation into an academic discipline and profession in 
later times. In this small yet renowned group, Anthony Grafton, one of the most prolific historians in the English-speaking world today, is a distinguished member. In this relatively small book, based on the author's four George Macaulay Trevelyan Lectures delivered at Cambridge University in 2005, Grafton demonstrates convincingly the importance of his work and of the history of history in general.

Using the writings of Jean Bodin [1530-1596], François Baudouin [15201573], and Francesco Patrizi [1529-1597], and also, marginally, that of their contemporaries and followers (e.g., Jacob Perizonius [1651-1715] and Jean Le Clerc [1657-1736]), he portrays the rise and fall of a forgotten tradition in historical writing between the sixteenth and the eighteenth centuries. The ars historica, or the "art of history," flourished during those two centuries-works in this genre, writes Grafton, “were written everywhere in Europe” (125). Its spread and success were as a result of the wide appeal of humanist scholarship in the textual restoration of Greek and Roman classical culture as well as in the new, hermeneutical examination of early Christian history and the New Testament, as shown in Erasmus [1466/1469-1536].

Yet the ars historica also went beyond the humanist tradition in two areas, the author argues. One was its expansive interest in knowing the then expanding world, thanks in part to the European expedition to and discovery of America and in part to Jesuits' missionary work in East Asia. The other was its broad range of research, extending from ancient texts to ancient objects, an antiquarian project in which the ars historica also belonged and from which it benefited (83-105). To mark it as a distinctive genre, two traits were developed that treated "history in a new way": to offer a comprehensive account across space and time and to base it on critical examination of the sources (32-33). But these two goals, Grafton states, are ultimately proven incommensurable, contributing to the demise of the ars historica (chapter four). For drawing on the humanist tradition, the practitioners of the ars historica were convinced that past examples were useful for guiding the present; and the more comprehensive their accounts were, the better. However, their interest in historia integra, which prompted them to integrate the knowledge about the New World(s), also, invariably, undermined their humanist "fetishization” of ancient Greek and Roman culture $(118,229)$.

But was the genre really dead? Perhaps not. Invoking E. H. Carr's What is History?, Grafton points out that the central issues concerning Bodin and Baudouin have emerged time and again in modern times (20). That is, historians today remain by and large committed to the critical use of sources for constructing a plausible account of the past, and such construction is often not short of a purpose: didactic 
or otherwise. There is no better example of ars historica's lasting influence than this thoughtfully crafted, beautifully narrated, and meticulously documented book. It indeed is a shining specimen of the "art of history" in our time.

Rowan University

Q. Edward Wang

The Vikings in England: Settlement, Society and Culture. By D. M. Hadley. (Manchester, England: Manchester University Press, 2006. Pp. xvii, 298. \$35.95.)

In no area of Europe outside Scandinavia was the impact of the Viking Age more widely felt than in England. As raiders and traders from the late eighth century, as land grabbers and settlers from the midninth century, and as conquerors and rulers from the late tenth through the eleventh century, the Vikings consistently saw England as the chief locus for their expansionist designs. Yet the material evidence for their presence has, in but a few places, not allowed firm conclusions about the scale of their settlement or the nature of the culture they imported and melded with indigenous traditions. Studies in archaeology, numismatics, placenames, and written sources have been as subject to fashion as any branch of historical studies. A stocktaking of what experts now know and what, indeed, is knowable is what D. M. Hadley sets out to offer, and as an archaeological practitioner with a string of highly reputable studies to her name, there can be few better qualified than she to provide it.

Surveying the various positions of experts in the field over the last sixty years in the opening chapter, Hadley concludes that it is not the lack of evidence that is the problem but the "conflicting impressions" that this evidence creates (20). Only through an interdisciplinary appraisal of the complexity of Anglo-Scandinavian interaction can these conflicts in interpretation be unified. Hadley begins by examining the vexed issue of just how the Scandinavians sought to accommodate themselves as rulers among Anglo-Saxons, particularly in the north of England. Although for some Viking leaders there was clearly the occasional necessity of asserting a specifically Scandinavian cultural identity, the general strategy was to imitate the established models of governance in European Christendom. Notions of entrenched in-group versus out-group conflict do not do justice to either Viking or Anglo-Saxon political nous and social flexibility. Although turbulence would have been commonplace in both rural and urban settings, at an institutional level, adoption and adaptation were the driving forces. The difficulties in assessing the numbers of Scandinavian settlers and discerning a precise Scandinavian imprint on the development of urban centers can, at least in part, be ascribed to cooperation on a day-to-day basis and even collusion with Anglo-Saxon powers in 
promoting centers of trade and production. Similarly the resilience of the AngloSaxon church has to be considered in the context of Scandinavians seeking acceptability and respectability and, in encouraging this, the willingness of the church in areas of Scandinavian settlement to adopt "innovative and sometimes controversial methods" in order to ameliorate the pagan (227). Perhaps not surprisingly, then, overtly traditional Scandinavian burial practices were the exception in circumstances where imitation of local traditions rapidly became the norm.

Hadley's moment of reckoning goes some distance toward bringing clarity to a confusing and complex area. It is likely to become a standard for those specializing in Viking Age studies for some years to come.

University of Hull

Martin Arnold

Einstein: His Life and Universe. By Walter Isaacson. (New York, N.Y.: Simon \& Schuster, 2007. Pp. xxii, 675. \$32.00.)

Why, fifty-plus years after his death, is there another biography of Albert Einstein? There are at least two reasons: first, new source material recently became available, and second, many people throughout the world are fascinated with Einstein. A host of prominent Einstein scholars, physicists, and a "nitpicker" read this book in manuscript, checking factual details, verifying the physics, and suggesting clarifications. Thus, this book can be read by all readers (no technical background needed), and it can be read with confidence. Often when authors take on a subject with the stature of an Einstein, they delight in bringing the subject down a peg or two. Walter Isaacson does not do this. Nor does he elevate Einstein into the realm of sainthood. This book is an engaging and evenhanded account of a great man.

Einstein's fame derives from his work as a physicist. In his twenty-five-chapter book, Isaacson devotes eight chapters to Einstein's physics, which he presents to the reader gently and clearly (there are no equations). The author recognizes the revolutionary nature of Einstein's 1905 paper proposing that light consisted of particles and that, in so doing, he was the father of quantum physics (for Max Planck, the quantum idea was only a mathematical device with no physical significance). The special and general theories of relativity are developed nicely in separate chapters. Also, Isaacson devotes chapters to the experimental verification of Einstein's light-bending prediction, which made him a worldwide celebrity; to Einstein's long struggle to unify his general relativity with electromagnetism, which, unlike other writers, Isaacson treats with understanding; and finally, to 
Einstein's last influential paper, published in 1935, on entanglement. Einstein's other important contributions to physics are sprinkled throughout the book.

Einstein accepted the fact that the formalism of quantum mechanics had the ability to predict experimental results; however, he did not accept the physical interpretations that were largely the work of Niels Bohr. In his chapter on Einstein's Nobel Prize, Isaacson highlights some of the differences between Einstein and Bohr. Again, the author understands Einstein's thinking and does not label him "stubborn" as other writers are prone to do.

This author provides insights into Einstein's private and public lives. Einstein was consumed by physics; consequently, his wives and children took second place. His divorce from Mileva Marić was messy, and, until his two sons matured, Einstein largely ignored them. Einstein was a celebrity, and he was sexy. As a result, women were readily available to him, and he took advantage of his opportunities.

Einstein was religious, but without a personal God; he was a Zionist, but would not move to Israel or be its president. Einstein was a pacifist; he rebelled throughout his life against authority. It is no easy task to capture Einstein in the pages of a book, but Isaacson provides readers with as complete a picture of this great man as they could hope for.

Washington University, St. Louis

John S. Rigden

Ruling the Later Roman Empire. By Christopher Kelly. (Cambridge, Mass.: The Belknap Press of Harvard University Press, 2004. Pp. 341. \$19.95.)

The author has written an interesting and perhaps even an important book. However, its title is misleading, the writing is often opaque, and the organization undermines the work as a whole. Apparently without realizing it, noted classicist Christopher Kelly has struggled with varying degrees of success to write a social history of bureaucracy in the later Roman empire. The focus in the first two chapters is on John the Lydian, a member of Justinian I's army of bureaucrats whose De Magistratibus provides the basic source and inspiration for Ruling the Later Roman Empire. In the next three chapters, Kelly employs a "flashback" technique, which takes the reader through a half-millennium from the Principate to late antiquity, demonstrating that history did not stand still. In these chapters, the author relates to the material treated in the first two chapters in no clearly defined way. Consistent with the curious nature of the author's organization of the book, which seems more a collection of essays than a monograph, Kelly provides an epilogue rather than a conclusion. 
In trying to evoke the sociopolitical milieu in which the bureaucracy functioned, Kelly does fine work in finding and commenting on literary descriptions of audiences, processions, and dress. In order to support the written sources, Kelly insightfully calls attention to various mosaics, medals, and other monuments, which illustrate from a different medium what is found in the written sources. However, Kelly makes the elementary mistake of failing to provide photographs of these materials. Seeing this evidence is essential to the reader's appreciation of the argument, as these materials were produced according to controlling assumptions that differ from those of the written sources.

Other serious limitations focus on Kelly's failure to deploy useful comparative research. For example, one looks in vain for the creative use of comparative material from literate premodern societies in places such as China and Prussia, where stimulating social science models have been well developed in the scholarly literature dealing with bureaucracy. An offhand reference to The Book of the Lord Shang [third century BC] and to Max Weber on Bismarck's bureaucracy illustrates that Kelly seems to grasp the importance of the comparative dimension, but also highlights his inclination not to give it the serious consideration it deserves. In the context of chapter five, "Autocracy and Bureaucracy," two books-W. H. McNeill's The Pursuit of Power: Technology, Armed Force, and Society since A.D. 1000 (Oxford: Basil Blackwell, 1983) and Charles Tilly's Coercion, Capital and European States (Oxford: Basil Blackwell, 1992)-have much to say of interest.

After a lengthy series of examples illustrating problems of various kinds with regard to the later Roman bureaucracy, Kelly concludes that "by comparison with a modern state, the system which emerged was hardly 'efficient'" (228). Kelly leaves the impression that there is some platonic universal "modern state." He provides no comparative data by which to judge the efficiency of bureaucracy in any real modern state nor, for that matter, does he provide data regarding the efficiency of the bureaucracy in the later Roman empire. In short, as with so many post-Finley devotees to a primitive past (i.e., "they are not like us"), Kelly does not survey the scholarly literature that looks toward seeing consistent patterns of behavior that are intrinsic to the bureaucratic phenomenon.

Reconstruction of how the later Roman bureaucracy was supposed to work in all of the immense detail, for example, the passing of "paper," that is available was avowedly not Kelly's aim. However, to critique what supposedly did happen on the basis of anecdotes of various kinds, selected from a wide variety of sources, often treated as plain text when it seems to suit the author's purpose, is not methodologically satisfactory. Although Kelly lays under contribution a large 
corpus of sources, a social history of later Roman bureaucracy remains to be written. Until this difficult and important task has been accomplished, Ruling the Later Roman Empire will be a useful work to be consulted by both scholars and graduate students.

University of Minnesota

Bernard S. Bachrach

Memoirs of Nikita Khrushchev: Reformer, 1945-1964. Edited by Sergei Khrushchev. (Providence, R.I.: Brown University Press, 2006. Pp. 865. \$65.00.)

Nikita Khrushchev's second volume of memoirs covers his rise to a major party leader from the late 1930s until the end of his tenure as party general secretary. (He does not discuss the Central Committee coup that swept him from power in September of 1964.) Khrushchev devotes some two-thirds of his memoirs to what he considered his greatest accomplishment-the reform of the harsh Stalin model, to "making life better" as he put it. Those interested in the rise of Soviet consumerism may find this material of value, but most will not. Khrushchev describes a litany of plans for building apartments and producing more consumer goods but does not devote one word to his decision to allow publication of the reform proposals of Lieberman.

The meat of this volume is Khrushchev's account of jockeying for power and survival during the last thirteen years of Stalin's life and the power struggle that followed his death. He brings to life the major players: the stubborn and bloodthirsty Molotov, the shifty and scheming Beria, and the "rolling stone" Malenkov, easily manipulated by others. Few are presented in a flattering light, except Khrushchev himself. The centerpiece of the volume is Stalin, who is pictured as growing increasingly frail, erratic, and paranoid. Virtually everyone in his retinue feared that one false move could spell his end. Those who survived Stalin, such as Khrushchev himself, drew a "lucky card." Others were not so lucky, falling victim of one palace intrigue or another, often instigated by the major villain of the story—Lavrenty Beria.

Khrushchev's account of his own actions is self-serving. According to Khrushchev, he tried his best to shield others from Stalin's wrath and even tried to talk sense to Stalin. On a number of occasions, Khrushchev felt that his own demise was imminent, but on each occasion he was miraculously saved.

In his account of Stalin's last years, Khrushchev is consistent with other accounts and adds relatively little. It does confirm the chaotic decision making during this period, with decisions either delegated to informal subcommittees or made ad hoc as Politburo members signed off on major decisions at dreaded 
midnight dinners at Stalin's "near" dacha. He describes Stalin's growing antiSemitism, which culminated in the brutal murder of the director of the Jewish theater in Moscow (and the arrest of Molotov's wife) and the failed assassination of Litvinov, the foreign minister.

Khrushchev's account of Stalin's relationship to Beria, Stalin's sole surviving NKVD/MVD chief, adds a new twist. Earlier Stalin carefully planned and carried out the arrests and executions of those he feared were threatening his power, such as Kamenev and Zinoviev or his state security heads, Yagoda and Yezhov. In the early postwar period, however, Stalin lacked the stamina and concentration to mount such a major campaign. As a result, he could not eliminate Beria, although he feared him. "If Beria could do these things on Stalin's instructions to the people at whom Stalin pointed the finger, then Beria could do the same kind of thing on his own initiative, choosing his own target" (58).

Khrushchev's account of the circumstances of Stalin's death adds little to the historical record. Perhaps his most interesting contribution is his self-serving account of the conspiracy to arrest Beria after Stalin's death. According to Khrushchev, it was he who recognized the dangers that a Beria regime would pose. He began lobbying against Beria already at Stalin's deathbed as he and Bulganin shared the night vigil. Immediately after Stalin's death, it became clear that Malenkov and Beria had agreed on a power-sharing arrangement that would not only give Beria control of state security, but also make him deputy prime minister. According to Khrushchev, he was the only one with the courage to organize a secret campaign against Beria, which required penetrating the mask of support for Beria put on by fearful party leaders. Khrushchev's most difficult task was persuading Malenkov that Beria was playing him for a chump. Somehow, the wily Beria remained blissfully unaware of the plot and was lured on false pretenses to a Politburo meeting where he was arrested by Marshall Zhukov and his men.

The final major contribution of this volume is Khrushchev's account of the events leading up to his famous de-Stalinization speech of February 1956 at the twentieth party congress. Most of Stalin's Politburo colleagues opposed revealing the atrocities of the Stalin regime for they themselves were implicated and such a revelation would destroy the credibility of the party. Khrushchev, who was himself as implicated as others, argued that the party must be given a true historical account, rather than the feeble story that maverick state security heads like Yezhov and Beria were to blame. The decision to present the speech and by whom was left open to the last minute.

It was Khrushchev's 1956 speech that was his major legacy on the course of Soviet and Eastern European history. It prompted the reformist movement in 
Eastern Europe and the Hungarian Revolution. Although the party remained in power, its credibility was indeed tarnished. The USSR itself entered a "period of stagnation" under the gerontocracy of Brezhnev, Chernenko, and Andropov, waiting for a youthful reformer who could solve its problems.

University of Houston

Paul R. Gregory

Sport and Spectacle in the Ancient World. By Donald G. Kyle. (Malden, Mass.: Blackwell Publishing, 2007. Pp. viii, 403. \$32.95.)

Gone are the days when scholars looked down on books about sports as frivolous or of marginal importance. Donald G. Kyle has now presented a book that not only examines the significance of sport in its own right but also most fruitfully explains its importance in the much larger affairs of ancient life. It is a pleasure to note that the author brings to bear his own valuable research on the topic. Thus he ably uses both the ancient sources and the broad secondary literature to excellent advantage. He also carefully defines and explains his topic and his appreciation of it in the introduction.

From there, the author investigates sport, meaning a history of it, not a study of the various games and competitions. For that, the reader must look elsewhere. Thus, he deals with the topic as it appears through time, which provides a welcome perspective of the topic. He accordingly deals with topics such as organization, the nature and meaning of the spectacles, their broader cultural importance, and their role in politics and propaganda.

Kyle quite appropriately begins by tracing the evolution of sport from hunting and warfare, charting its development from these bases to social spectacle. His treatment begins with Mesopotamia and Egypt, when its earliest organized forms evolved into combat sports and running contests. He traces sport among the Hittites, Minoans, and Mycenaeans, and uses sport to trace elements of cultural contact and borrowing. The author's treatment naturally hits full stride with the classical Greeks to whom sport and spectacle became intimate and essential aspects of culture itself. Here the great games-Olympic, Pythian, Isthmian, and Nemean-take pride of place, demonstrating how sport became a basic part of the very definition of the Greek ethos. The author treats the broader ramifications of sport, examining such topics as its impact on politics-including the role of both public and private patronage-literature, and Greek culture. He cogently treats the role of women in public sport, including them as participants and spectators. Here Kyle introduces a welcome touch of realism to an often disputed topic. 
Roman sport made its own contributions to the art. The most notable were gladiatorial contests, combat with animals, and ordeals among criminals. Kyle deals frankly with this bloody and brutal aspect of the topic. He sensibly takes it as a part of life, no better or worse than that of many other cultures. The popularity of these contests is itself worthy of careful attention for what it tells about the audience. Gladiators, chariot drivers, and even successful criminals were found in the arena, a place where they could become the idols of society. The author concludes with the lethal impact of Christianity on classical sport. Although the deep-seated cultural traditions of such popularity cannot be eliminated overnight or by decree, Christianity considered this one dangerous to salvation. The Emperor Honorius officially sealed its demise when he closed the gladiatorial schools in Rome in 399.

Whether a fan of sport or not, every reader will find something of interest and value in this book.

Urbana, Illinois

John Buckler

Napoleon's Master: A Life of Prince Talleyrand. By David Lawday. (New York, N.Y.: Saint Martin's Press, 2006. Pp. xiv, 386. \$26.95.)

The author of this biography of Talleyrand, France's leading diplomat during the revolutionary and Napoleonic era and one of the main architects of the Vienna peace settlement, makes no pretense of providing a new perspective on its subject. David Lawday echoes earlier biographers in tracing the twists and turns of Talleyrand's life, which saw him adapt and survive under successive regimes from the ancien régime to the July Monarchy. Lawday also retells the well-known story of Talleyrand's complicated private life, whose highlights included a virtual ménage á trois with the American ambassador Gouverneur Morris during the early 1790s, an inexplicable marriage to a socially inept beauty after he left the Church, and, in his later years, a happy household including both the duchess of Kurland and her daughter.

As the title suggests, Lawday's biography focuses primarily on Talleyrand's relationship with Napoleon, fifteen years his junior. Napoleon valued Talleyrand's skills in converting military successes into diplomatic and territorial gains; Talleyrand admired Napoleon's leadership abilities and took advantage of the opportunity to enrich himself by demanding bribes from foreign governments. By the midpoint of Napoleon's reign in 1807, however, Talleyrand began to fear the consequences of Napoleon's boundless ambition. Lawday hyperbolically describes the resulting conflict between the two as "a fight to the political death," 
although in fact Talleyrand could do little beyond remaining in covert contact with Napoleon's opponents until after the military disaster in Russia (207). As the regime crumbled in 1814, Talleyrand briefly took center stage, persuading Allied leaders to accept a restoration of the Bourbon monarchy, with guarantees to those Frenchmen who, like Talleyrand, had participated in the revolutionary and Napoleonic regimes. At the Congress of Vienna, Talleyrand successfully reasserted France's right to recognition as a great power and blocked Russian and Prussian demands that would have drastically changed the European balance.

As a biographer, Lawday faces the challenge of squaring his admission that Talleyrand always concealed his true thoughts with his own assertion that Talleyrand was a man of principle, consistently opposed to "the lust for empire and territorial expansion" (67). The author, whose sketchy knowledge of the period's broader historical background leads him into many minor factual errors, never makes a convincing case that the other powers would have tolerated France even if it expanded only as far as the "natural frontiers" that he thinks Talleyrand would have accepted. As Lawday shows, Talleyrand's supposed devotion to principle was constantly undermined, both by his insatiable appetite for personal gain, and, more fundamentally, by his compulsion to stay close to the center of political power. He helped implement many Napoleonic decisions he criticized in private, and avoided a complete rupture even after the Emperor famously denounced him as "a shit in a silk stocking" in front of other courtiers (2). Talleyrand certainly had a hand in Napoleon's downfall in 1814, but to call him "Napoleon's master" is an exaggeration.

Lawday's account is not, as he claims, the first serious biography in English since 1932; his bibliography omits both Crane Brinton's standard study, The Lives of Talleyrand [1936], and J. F. Bernard's more detailed Talleyrand: A Biography [New York, N.Y.: G. P. Putnam, 1973]. ${ }^{1}$ Lawday does an adequate job of telling the story of Talleyrand's life, but the man himself remains an enigma. Whether the world would be better off with a Talleyrand guiding the actions of "our world's lone superpower" today, as Lawday suggests, remains an open question (3).

University of Kentucky

Jeremy D. Popkin

1. Philip Dwyer, Talleyrand (New York, N.Y.: Longman, 2002), is marred by extensive unacknowledged borrowing from Bernard's book. See the review by William Olejniczak in H-France Review, 5 (March 2005), no. 28, online at http://www.h-france.net/vol5reviews/ olejniczak.html. 
North-East England, 1569-1625: Governance, Culture and Identity. By Diana Newton. (Woodbridge, England: Boydell Press, 2006. Pp. x, 214. \$85.00.)

Pleasingly, the author does more or less exactly what she promises in the title. She asks whether or not regional identity in Durham and Northumberland was being eroded in the later sixteenth century. In other words, this is a book, in some sense, about the advent of modernity, a theme that is, of course, embedded in many historical texts about major events in this period, notably the coming of the Reformation. Here one group of historians (particularly those whose research focuses on England's northern counties) tends to stress introversion, backwardness even, and cultural conservatism, while another group talks primarily of commerce with Europe, the rise of a (Protestant) national identity, and so on.

In her introduction, Diana Newton convincingly brings out the significance of this issue. Extending her earlier work on the accession of James VI of Scotland as King of England in 1603, she discusses whether the border regions in northern England became fully integrated into the new Stuart realm of Britain. Whether they were thus integrated or not would be crucial for the stability of the regal union.

The author then deals with a series of topics designed to reveal whether her chosen counties were indeed culturally different in kind from other regions. Of course, historians know that contemporaries did remark on exactly such differences. In 1609, a leading Catholic secular priest, Benjamin Norton, joked that only Northerners were able to deal with wily Scots. And yet, of course, regional gentry families (not just from the North) frequently resorted to London and in that sense their political, social, and cultural experiences were not confined to their own region. Newton concludes, as indeed other scholars have done, that in this period "the concept of regions as a foundation upon which to construct identities remains problematic" (163). Undoubtedly, to some contemporaries, northern patterns of speech sounded "clownish." But the concept of civility was not exclusive to the South or to the metropolis. As she points out, in this context, even in Durham and Northumberland distinctions were made between manners in town and country (108).

Nevertheless, clearly historians can identify significant political issues and attitudes that were located particularly, even if not exclusively, in the North during this period. Although she is not the first to have done so, Newton clearly demonstrates that major political questions, notably the Reformation, generated political opinions in this part of the country, which, in the eyes of contemporaries, marked it off from other areas. 
A good deal of the book is about religion. On the basis of the evidence that she presents, there is clearly, for example, a link between the prevalence, among some gentry families and their retainers, of Roman Catholicism and the reputation for the ungovernability of the English borders. Here, she shows convincingly, Catholicism takes forms that are, in some ways, rather different from the style of religious conservatism found in other counties. This sort of thing really does matter for the history of the period, and indicates quite a lot about other contemporary questions, for example, the debates over toleration, the conflict between groups and factions defined by different religious identities, and, more generally, the problems caused by the union of the crowns in 1603 . But what all of this does not tell historians, as Newton sensibly concludes, is that they can identify what looks, from time to time, like distinctively regional attitudes by reference merely to something different in the water or in the air north of a particular geographical point in the British Isles.

Queen Mary, University of London

Michael Questier

Riotous Assemblies: Popular Protest in Hanoverian England. By Adrian Randall. (Oxford, England: Oxford University Press, 2006. Pp. xi, 354. \$150.00.)

The phrase "reading the Riot Act" continues in common parlance, generally divorced from its original context. This author's excellent comprehensive study reestablishes that connection, firmly grounding the Riot Act in the rambunctious history of riot in eighteenth-century England. Adrian Randall's work benefits from the attention paid to popular disturbances by other historians over the past fifty years, and he carries on a productive dialogue with his predecessors as he works through a chronological and thematic assessment of the century's changing landscape of disorders. This historiographic synthesis makes Randall's work particularly useful for students new to the topic. Randall demonstrates an impressive mastery of relevant primary sources, providing readers with a careful analysis of specific disturbances, reaching down through the sources, to get at the frequently obscure voices of the rioters themselves. Randall apologizes in the preface for the lengthy gestation of Riotous Assemblies, but the time he took has paid off in meticulous scholarship and thorough synthesis of what was going on amongst the common folk engaged in riot over the course of the century.

Randall focuses on both change and continuity in motivation to riot, and in the forms taken by riot over the course of the eighteenth and early nineteenth centuries, culminating in the Luddite disturbances at the end of the Napoleonic wars. The overarching change from a largely traditional economy, characterized 
by paternalistic regulation, to an industrial economy dominated by "Dr. Smith's disciples" forms the backdrop for the study, with digressions into more directed religious and political rioting. Randall's fundamental argument is that although the era was one of tremendous and multivariate change, there remained a fundamental continuity in how and why working-class Englishmen and women responded to those changes.

The people's response to community crisis, Randall argues, was rooted in a long tradition of popular disturbance, stretching back to the peasant rebellions and food riots of the later Middle Ages. Thus, Randall observes, even when the circumstances of the people changed, their sense of the justice and legitimacy of their protests, their belief in the protections offered by common law and precedent, and their conviction that magistrates could and should intervene to uphold community norms, remained constant through the century. Randall likewise examines the widespread use of ceremony, symbol, and ritual to dramatize and give the aura of legitimacy to the arguments of both rioters and, increasingly, their industrial and governmental opponents.

Randall pays less attention to "the establishment," which plays a secondary and largely unsympathetic role in his account of the changing climate of work and protest, and the reader should look elsewhere for the parallel development of government, finance, and the positive aspects of industrial innovation. Fortunately, these areas have their historians as well, and solid studies can be read as companions to provide a fuller picture of the transformative eighteenth century.

Riotous Assemblies sets the standard for current scholarship on popular disturbances in early modern England. Its accessibility and attention to historiography makes it particularly well suited for advanced undergraduate and graduate libraries.

Saint Vincent College

Susan Mitchell Sommers

Medieval Polities and Modern Mentalities. By Timothy Reuter. Edited by Janet L. Nelson. (Cambridge, England: Cambridge University Press, 2006. Pp. xix, 483. \$100.00.)

This volume contains a collection of twenty-two papers, five previously unpublished, written by a brilliant historian of the Middle Ages to whom death came early. Happily they have been brought together and meticulously edited by Janet L. Nelson. Perhaps because they range so widely in topic, no subtitle is provided to anchor the general title of the book. The main anchorage is Germany from the 
Carolingian epoch to the twelfth century, a very large part of medieval Europe, which now becomes much more accessible to readers of English. But the book defies such a description, for it offers comparative interpretations of themes woven into European-wide medieval regional histories, often seen here from the standpoint of the history of Germany. This is a challenging book in the good sense that it constantly and especially provokes those historians who do not study medieval Germany to question their assumptions and preoccupations.

Every chapter raises sharp questions to which the answers suggested point to further debate and enquiry. As Timothy Reuter intermittently shows, the different regions and nations of medieval Europe have their different historiographies, partly because of what the surviving evidence allows their historians to work on (crime in medieval England, e.g., but not in medieval Germany-Reuter provides a corrective chapter), but also because these historians work within particular historiographical traditions. On these "tyrannous constructs," and as a historian of medieval Germany in particular, Reuter casts a critical eye, especially when the study of medieval Europe is largely reduced to the study of medieval France-as in recent debates over the "feudal revolution"—and when the study of medieval English kingship is not approached as the anomaly that, from a central European perspective, it would seem to be.

Reuter was exceptionally erudite. Very few recent historians could make such telling use on a single page (page 44 has been chosen entirely at random, but is typical) of Robert of Torigny, Saxo Grammaticus, Snorri Sturluson, the Glossary of Cormac, the Peterborough Chronicle, and the Erfurt Annals. Moreover, Reuter was a master of many different historical registers: politics and society, obviously, but also the norms other than laws and institutions that governed political behavior and thought. A recurrent theme in these chapters is the relationship in the act of ruling between status, action, and style. Forms of rulership and the patterns shaped by rituals, ceremonies, and gestures keep coming to the fore without, however, supplanting basic factual narrative. All the chapters tackle difficult and often elusive topics and shed sharp light on them, too. They include the role of symbolic acts (staging) at Canossa and in the Becket dispute, the insecurity of travel, assembly politics, and much more, especially on how rulers ruled. The best chapter is perhaps chapter eighteen, on "The "Imperial Church System' of the Ottonian and Salian Rulers: A Reconsideration.” First published twenty-five years ago, it has certainly proved to be highly influential. 
To Have and To Hold: Marrying and its Documentation in Western Christendom, 400-1600. Edited by Philip L. Reynolds and John Witte Jr. (Cambridge, England: Cambridge University Press, 2007. Pp. xvi, 519. \$75.00.)

This collection of thirteen essays, most of them written for this volume, focuses on the ways in which changes in the laws and practice of marriage in the medieval West are reflected in changes in the official presentation and documentation of marriage negotiations, ceremonies, and conflicts. The contributors are a who's who of major legal and legal-social historians: Judith Evans-Grubb, David G. Hunter, Philip L. Reynolds, Laurent Morelle, Cynthia Johnson, R. H. Helmholz, Frederik Pedersen, Art Cosgrove, Agnes S. Arnórsdóttir, Thomas Kuehn, Martha C. Howell, and John Witte. Two of the chapters, David Hunter's and Art Cosgrove's, are revised versions of pieces published earlier (2003 and 1985, respectively), and the Morelle chapter is a translation of an essay published in French in 1988 .

It would take far too long to describe each essay individually, so a general description must suffice. All of the authors focus on the kinds of documentary sources that describe and proscribe marriage in the West from the late Roman Empire (Evans-Grubb and Hunter) to the Reformation (Witte). Both secular and canon law texts are included in this analysis, but the emphasis is on the relationship between the stated legal stipulations regarding marriage and the documents that illuminate the ways in which marriage was experienced by people living in different European regions and cultures, ranging from Florence (Kuehn) to Iceland (Arnórsdóttir). Some chapters, such as those on Iceland and Ireland (Cosgrove), and Helmholz's chapter on England, strive to present a more general overview of the medieval period in those regions. Other chapters are more specific, focusing on the twelfth century (Morelle and Johnson), the late Middle Ages (Pederson and Howell), or the early modern era (Kuehn and Witte). Although there is a shared thread running through the volume, the chapters themselves operate as well individually as they do collectively.

Three aspects of the collection stand out. First, the introductory chapter by Philip Reynolds operates as an essential guide to the relationship between canon and secular legal traditions with respect to marriage, as well as an introduction of the remainder of the volume. It should be required reading for any student working in legal history. Second, most of the chapters include appendices of translated documents. This is phenomenally useful pedagogically: the topics under discussion are esoteric and difficult, and the opportunity to engage students in textual analysis of primary sources while they are struggling with the concepts is 
most welcome. Third, the geographical diversity of the volume, including, as it does, Iceland and Ireland in addition to more "traditional" regions such as England and France, provides glimpses into other medieval regions that students rarely encounter in specialized collections such as this one.

This collection is not perfect-there are no chapters on the Holy Roman Empire, the Kingdom of Sicily and Southern Italy, or Christian Iberia, all essential parts of "Western Christendom"-but it is certainly an excellent contribution to the growing trend in medieval studies toward a more inclusive and comparative view of the medieval world.

Alfred University

Linda E. Mitchell

Fascism's European Empire: Italian Occupation during the Second World War. By Davide Rodogno. Translated by Adrian Belton. (Cambridge, England: Cambridge University Press, 2006. Pp. xxi, 504. \$99.00.)

Readers of popular fiction or viewers of movies may have seen depictions of Italians in the Second World War as lovers rather than fighters. As occupiers, they were more likely to woo the conquered with mandolins than to persecute their perceived inferiors. Davide Rodogno's 2003 work Il nuove ordine mediterraneo substantially revised this romanticized view of the so-called brava gente-of the Italians as the war's good guys. He demonstrates in detail the often brutal nature of fascist wartime occupation and the sweeping aims of Italian racialist policy. English-language readers now have access to this excellent monograph thanks to Adrian Belton's fluid translation.

Rodogno argues that historians need to understand fascist Italy's projects and its aims in the territories that it conquered during the war. He investigates several interrelated questions: How did Italy plan to deal with occupied France, Yugoslavia, and Greece? What would the new world order that dictator Benito Mussolini aimed to create look like? Did the Italian army share Mussolini's vision? How did Italy work with and how did it seek to obstruct its German ally? Did Italian zones of occupation serve as safe havens for Jews and other refugees?

Rodogno's account covers a wide array of issues, including Italy's occupation policies, its relations with Germany, its attempts to exploit occupied territories' economies, the relationship of fascist ideology to the administration of occupied territories, legal and jurisdictional questions, forced Italianization, collaboration by subject populations, and the Jewish question. He concludes that Fascist Italy aimed to conquer a spazio vitale-a vast empire in the Mediterranean-and to 
overthrow British and French plutocratic domination. Mussolini's new order would provide space and resources for and would help to create a new fascist man, convinced of Italian racial supremacy and prepared to rule the empire with a rod of iron.

In spite of these sweeping aims, German economic power and contempt for its junior Italian ally severely curtailed Italy's freedom to maneuver in territories conquered not by Italian efforts but by German feats of arms. As rebellions against fascist and Nazi occupation gained strength, the desperate Italian response became increasingly brutal, mirroring the tactics of Nazism, if not the frequency and intensity of the Nazis' abhorrent violence. Although some Italian generals and diplomats worked on a personal basis to save refugees, the state and most of the military made no attempt to rescue the persecuted, and, in fact, cooperated to a degree with Nazi atrocities, turning over Jews and other refugees to their persecutors.

Rodogno relates this disturbing story exceptionally well. His research is first-rate. He has worked assiduously in Italian archives and provided comprehensive and compelling findings. He is careful with the resulting evidence, clearly understanding its importance but also its limits. His explanation is meticulously organized and presented, and nonspecialists will be able to follow the chain of argument easily. Rodogno cautiously offers this work as a first step in understanding Italy's occupation policies during the war, but he has accomplished far more than that limited aim. This book will be the standard for years to come, at least until the release of currently closed archival evidence allows future historians to complement Rodogno's persuasive research and argument.

Lakehead University

G. Bruce Strang

Justinian's Flea: Plague, Empire, and the Birth of Europe. By William Rosen. (New York, N.Y.: Viking Press, 2007. Pp. 367. \$27.95.)

As a longtime editor and publishing executive, the author of this book could have made his first book a model of popular history. Instead, Justinian's Flea exemplifies most of the defects of popular history today.

The author discusses, in no logical order, the reign of the Byzantine emperor Justinian (527-565 AD), the sixth-century bubonic plague, and various themes in Eurasian history, inserting bits of argument so disorganized that they defy summarizing. Apparently aiming at an informal but erudite style, William Rosen writes portentous sentences filled with metaphors and clichés. For example, Rosen 
declares of Boëthius' "Consolations [sic] of Philosophy," "[T]he Ostrogoth king's caution grew into a paranoid episode that would lead directly to the creation of a work that, more than any other, marks the intellectual doorway between the classical world and the medieval world that would replace it" (65). Later we read in a description of the biology of the plague, "This circular journey, the linchpin of the three processes by which sugars are turned into energy, is such a remarkable energy motor that it is still very much the gold standard even among Johnnycome-lately species like Homo sapiens" (180). There are also outright solecisms, like "internment" for “interment" (216), "Frank's" for "Franks" (256), and “immiseration" for "impoverishment" (270).

The endnotes and bibliographical note mix primary sources, scholarly works, obsolete scholarship, popularizations, and whatever Rosen found on the Internet. He makes such howlers as that Augustus founded the Roman Empire "in 74 C.E.," Constantinople was "in Asia Minor" (4) and fell to the Turks in "1458" (320), "Roman Armenia" is "today's Azerbaijan" (248), Justinian and Theodora are saints of the "Eastern Orthodox Church" (273), Maurice's Strategikon (c. $600 \mathrm{AD}$ ) is "eighth-century" (279), the philosopher-bishop Synesius was a "historian" (302), and the fourth-century martyr Demetrius of Thessalonica "wrote" about the plague in 597 (313). Rosen confuses mosaics in Ravenna with frescoes (160), Arianism with Monophysitism (257), and Monophysitism with Eastern Orthodoxy (274). Because none of Rosen's notes includes page numbers, the origins of his errors are hard to identify; but an estimate in a book by this reviewer that the sixth-century empire had a maximum of twenty-six million people seems to be his misremembered source for writing that "twentyfive million fewer people lived in the empire at the end of the sixth century as did at its beginning" (309).

Although this book is full of mistakes no scholar would make, it does avoid mistakes only a scholar would make. To take a recent example, Chris Wickham's Framing the Early Middle Ages (Oxford, 2005) asserts that the plague was unimportant and the European economy revived around 750 because feudal lords forced peasants to produce more- a Marxist assumption that people work harder under compulsion that is unsupported by medieval evidence and was disproved under Stalin and Mao. At least Rosen realizes that the European economy revived because population growth rebounded when the plague stopped. Yet his book is so inaccurate and poorly written as almost to give common sense a bad name. 
Before the Deluge: Public Debt, Inequality, and the Intellectual Origins of the French Revolution. By Michael Sonenscher. (Princeton, N.J.: Princeton University Press, 2007. Pp. x, 415. \$39.95.)

This brilliant book offers a remarkably fresh approach to how eighteenth-century intellectuals understood revolution before and during the French Revolution. Although their principal referents harked back to Aristotle's Politics and ancient Rome, these men-most well known, such as David Hume, the Baron de Montesquieu, and Jean-Jacques Rousseau, but some less so, like François Véron de Forbonnais and Pierre-Louis Roederer-knew their own times differed markedly as a result of the rise of commercial capitalism and its attendant social values. Consequently, they all grappled with the problem of adapting time-worn explanations of social and political change to explain their own-and ultimately our-brave new world.

Michael Sonenscher captures not just the intellectual creativity but also the psychological angst these men felt. His basic argument turns on how they understood the nature and effects of public credit on government, society, and morality. The ability of governments to borrow money to finance war grew exponentially during the eighteenth century. The central paradox that observers at the time considered was whether governments ultimately ruined public order in their ruinously expensive efforts to advance it. Sonenscher takes up these problems in a fairly elliptical fashion, frequently shifting the chronological frame of reference in four rather lengthy chapters. But attentive readers are well rewarded for their efforts to follow him along these highways and byways of enlightened political theory and thought.

The author begins chapter one with the French Revolution and projects backward in order to unpack why French contemporaries, particularly the Abbé de Sieyès, came to view it the ways they did. Previous debates over the pros and cons of English constitutionalism proved central and pointed to the problem of defining ideal government anew as social wealth increased. Montesquieu's own thinking on these questions dominates chapter two. Sonenscher emphasizes the evolutionary nature of the baron's views (as he does for most figures he examines). Montesquieu devised a very original solution to the problem of creating a political regime strong enough to ensure public order but not strong enough to become a threat to it. Here the management of public credit, and by implication the safeguard of private property, proved essential in redefining the sovereign's authority.

Morality lay at the core of these debates among philosophes and physiocrats, as Sonenscher argues in chapter three. The capacity of contemporary societies 
to strike this delicate yet essential balance turned on their ability to encourage public virtue, or at least stave off the risks of public corruption. In this respect, these arguments over political economy retained the original ethical, indeed theological, sensibility and language inherited from the past. Although some thinkers, such as Rousseau, argued for agrarian simplicity and republican austerity, others like Jacques Turgot recognized both the inevitability and advantages of encouraging the prevailing commercial and industrial ethos as the basis for modern government.

As explained in chapter four, attempts to square rising levels of wealth and public indebtedness with a stable constitutional order inspired and bedeviled thinkers, such as Roederer and Jean-Baptiste Say, who lived through and tried to understand, if not direct, the course of the French Revolution. Although Napoleon initially seemed to strike this necessary balance, his subsequent dictatorship and eventual fall left these essential problems unsolved. As a result, Sonenscher concludes, they established an enduring, now wholly modern agenda for political theorists to ponder in the future.

This brief review cannot begin to capture the nuance and sophistication of Sonenscher's careful, complex archaeology of the intellectual origins of the French Revolution. He reminds readers that all the thinkers he profiles experienced the creation of the modern European world over a lifetime, changing their minds, reformulating questions, and reexamining inherited ideas as events unfolded, trying to hit on if not universal then at least workable solutions to the perdurable problems of balancing liberty with security. We can appreciate the difficulties they encountered during their journey if only because it continues in our own day, and for that abiding lesson we have much for which to thank Michael Sonenscher.

St. John's University

Michael Wolfe

Hitler's Home Front: Württemberg under the Nazis. By Jill Stephenson. (New York, N.Y.: Hambledon Continuum, 2006. Pp. xvi, 512. \$34.95.)

How effective was the Hitler state at realizing the regimented "national community" of Nazi rhetoric? Not very, argues Jill Stephenson. Her finely textured analysis of the politics of everyday life in the hinterlands of southwestern Germany underscores the widely acknowledged difficulty of reducing grassroots behavior in the Third Reich to simple categories of support and opposition. Focusing on rural Württemberg, Stephenson explores local ramifications of Nazi 
racial and religious policies and details the impact of wartime exigencies on communal values and relationships. Despite a decade of propaganda and coercion, she concludes, the regime's "quest for total control was not achieved and, furthermore, was not realistic" (350).

This was as a result in part of the weakness of the local Nazi infrastructure; in hundreds of small Württemberg communes there was no party apparatus whatsoever. As a result, implementation of official policy was often inefficient, inconsistent, and colored by local customs and assumptions. More broadly, Stephenson argues, Nazi priorities ran counter to the deeply ingrained values of backwater communities shaped by nonmechanized family farming, endogamous social networks, and time-honored religious attachments. The regime's emphasis on industrial expansion and rearmament threatened to ignore rural needs, despite ritual obeisance to the primacy of blood and soil. Many country folk instinctively distrusted the new order as another centralized exercise in urban condescension, an affront to commonsense traditional ways that remote functionaries neither understood nor respected. As Stephenson shows in considerable detail, rural resentment against externally imposed change grew exponentially during wartime, fueled by intrusive commodity regulations, military call-ups that stripped farm villages of desperately needed manpower, and waves of refugees and forced laborers billeted on resource-strapped communities congenitally skeptical of incomers and their alien outlooks. In most cases, villagers' responses reflected a rough and ready ethic of selfinterest; if they sometimes accommodated "subhuman" forced laborers more readily than they did Aryan "national comrades" from bombed-out cities, this bespoke not so much disagreement with Nazi racial dictates as the simple fact that such laborers usually made better farm hands than displaced city dwellers.

Much of Stephenson's account echoes themes found in previous studies; it clearly invites comparison with Ian Kershaw's well-known 1983 study of popular opinion in neighboring Bavaria. Stephenson's findings touch on several classic debates in Third Reich historiography, including the extent to which National Socialism should be viewed as a modernizing force, and although specialists may quarrel, for example, with where she elects to locate rural Württemberg on the continuum of conformity and dissent, all readers will likely appreciate the wealth of local detail she has unearthed to support her conclusions. This meticulously documented volume adds to a growing list of recent studies-those of David Blackbourn, Alon Confino, and Helmut Walser Smith, for example-whose careful attention to the idiosyncrasies of Württemberg 
culture and society simultaneously serves to illuminate and recast broader questions of identity and experience in modern Germany.

The Resilience of the Spanish Monarchy 1665-1700. By Christopher Storrs. (New York, N.Y.: Oxford University Press, 2006. Pp. 271. \$110.00.)

The years 1665-1700 have been customarily seen as the low point in the so-called "Decline of Spain." The author has marshaled ample resources to show that Spain still had to be reckoned with on the European scene. Christopher Storrs provides a gold mine of information about Spain and, above all, Castile, although the reader had best know the history of the period before taking it up. He begins with a thoughtful discussion of the historiography of decline of Habsburg Spain, which he means to influence with his case for a more resilient Spain. Although that historiography traditionally tends to see Spain's regeneration with the coming of the Bourbon dynasty in 1700, it has been lately argued that it began in the 1680s. Storrs concurs and provides the evidence.

Storrs presents the evidence thematically, with the army, the navy, finances, Castilian politics, the Aragonese kingdoms, Italy, and the New World. This approach does entail a good deal of jumping around and repetition. Many of the issues were widespread and of long standing; Storrs tends to admit as much in a passing manner. For the armed forces, readers learn about equipment, manufacture, provision, costs and recruiting, regulars and militias, but little of wars or battles save their mention. For finances, readers learn the way money was raised and spent, how loans were acquired, and how debt was serviced. For the currencies used, he provides a brief paragraph on ducats, escudos, maravedís, and their value relative to each other, but little about their worth or relation to pesos, pistoles, or other currencies he mentions. In politics and government, readers find the names and offices, the intrigues and rivalries, the role of the Cortes, but little to nothing about personalities. Storrs cannot seem to make up his mind on the competence of Carlos II, plagued by debilitating health, though at one point he takes most seriously a memorandum from Carlos, written at age fifteen. Carlos's half-brother Don Juan José de Austria does get properly introduced, after he has been mentioned as Don Juan de Austria, as he most often is, which might confuse him with the more famous Don Juan de Austria [1547-1578] (154). But who indexed him under "Don"? The index can use help: no "Velasco."

Storrs's bibliography is excellent. Also, much useful information and comment can be found in his footnotes, which occupy a quarter to a third of most pages. In 
the chapter on "The Centre and the Periphery in the Spanish Monarchy," lists of the viceroys appear in notes. Aragon had a Cortes, not Corts as in Catalonia and Valencia. Throughout the study, Storrs rightly stresses the determination of Carlos II and his advisers to defend and preserve the monarchy as he inherited it, though when it comes to the diplomacy around the Spanish succession, this is not the place to look.

Though college and university libraries should have this important book, most students would best begin with Henry Kamen, Spain in the Later Seventeenth Century, 1665-1700 [New York, N.Y.: Longman, 1980].

Santa Clara University

Peter Pierson

The Trojan War: A New History. By Barry Strauss. (New York, N.Y.: Simon and Schuster, 2007. Pp. xxii, 258. \$26.00.)

According to the publisher's announcement, this book is the first full military history of the Trojan War, a striking claim for a topic that was long thought to belong to a "fabulous age of Greece which must have no place in history" and continues to provoke furor. On 25 February 2003, The Times (of London) reported that "A NEW Trojan war ... has broken out among archaeologists over the size of the fabled city of Homer's Iliad." Although "fabled," Troy has attracted the attention of many who believed in the actuality of that war. Building on the industry of archaeologists, historians, linguists, and classicists, Barry Strauss presents a compelling and engaging account of such a confrontation in the late Bronze Age at the site most believe to have been ancient Troy.

The author states his belief at the outset: "We can presume that the Trojan War indeed happened" (7). His reasonable method of supporting this belief is to set the traditional tale of the confrontation between Achaeans and Trojans in the context of the age in which Greeks of the Classical Age, including the historians Herodotus and Thucydides, as well as many modern historians, classicists, and archaeologists, think that it occurred.

Consider the cause of the conflict. We know little of the lovely Helen who deserted her husband Menelaus for Paris, but we can learn much about marriage, polygamy, divorce, and adultery from surviving records of the Egyptians and

2. S. E. Bassett, The Poetry of Homer (Berkeley, Calif.: University of California Press, 1938), 244. 
Hittites. As the author concludes this chapter, "No wonder that, centuries later,... Herodotus' comment that when Paris ran back to Troy with Helen wife-stealing was an old custom" (28).

Warfare is similarly situated in the Bronze Age. Archaeological evidence illustrates the nature of the ships that carried the Achaeans across the Aegean; the types of troops and their organization for battle are known from records of contemporary kingdoms. These accounts can breathe life into speeches in the Iliad as part of use of "pre-battle speech, which was already an ancient tradition" (56). They reveal conditions of prolonged encampment akin to the account of a general in the fourteenth century, lamenting "now, for five months the cold has been gnawing me," that could surely inspire the sort of flight of troops recounted in Book Two of the Iliad (109). Even the Trojan horse might be understood in light of the nature of deceit in Hittite military strategy.

Clearly and engagingly presented, the text is enhanced by useful maps, a succinct timeline, a glossary of key names, a full bibliography, and a number of handsome illustrations conveying the reader to the site now generally regarded as Bronze-Age Troy.

"Generally regarded" may serve to suggest the reception of the book: many will regard it as an excellent gauge for supporting the historicity of the war recounted in the Iliad, but it is certain that others will continue to fight the war over Troy.

University of Washington

Carol G. Thomas

Catherine the Great. By Michael Streeter. (London, England: Haus Publishing, 2007. Pp. 167. \$15.95.)

The "greats" Peter and Catherine, to the exclusion of all other Russian rulers, with the possible exception of the "terrible" Ivan, have attracted writers and audiences ever since their deaths, and clearly continue to do so. The twentieth century witnessed a stream of biographies and studies devoted to both rulers, and in its last decades saw the publication of works of true scholarly distinction, introducing a vast array of often new sources and marked by perceptive analysis. Catherine has been particularly well served in the Anglo-American world by such authors as J. T. Alexander and Simon Dixon and, to universal acclaim, by Isabel de Madariaga. Anglophone practitioners of popular biography may now plumb these works for reliable material, whilst adding their own emphases of sex and sensation, seen most recently in the title of Virginia Rounding's Catherine the Great: Love, Sex and Power [2006]. 
There seems, however, to be little or no reason why the book under review should have been written, other than whoever devised the "Life and Times" series for Haus Publishing felt that Catherine could not be omitted and that there would be an adequate public in financial terms for another retelling of her story. Michael Streeter, an experienced journalist and author, already has one title in the series under his belt-on General Franco [2005]—and so obviously knows the rules of the game, but Catherine is a rather different proposition from Franco. Streeter has no Russian and has turned to a dozen or so of the best English-language sources that have appeared since the 1970s, including the authors mentioned earlier. It is in their English that he makes his few quotations from original sources, overwhelmingly from Catherine's memoirs and letters.

The end result is a concise, readable, and balanced account, organized in ten chronological chapters, that seeks to show the empress "as one of the most remarkable rulers" in Russian history, not dwelling on her "warts" and underlining her undeniable claims to greatness (143). For that at least readers should be grateful.

The main text is a mere 143 pages long, and that includes some twenty-five, sometimes full-page, photographs, as well as numerous short "bullets" of information on characters and events mentioned en passant. In addition to the notes, there is a historical spreadsheet and recommended reading. The illustrations, probably assembled by some "photographic researcher," are a motley assortment that do not indicate source or artist and include one gigantic error: the full-page portrait on page eighty-five is indeed of Potemkin, but not the Prince Grigorii Aleksandrovich, beloved by Catherine, but Petr Ivanovich, Russian ambassador to the English Court in 1681-1682 and there painted by Godfrey Kneller.

Fitzwilliam College, Cambridge

Anthony Cross

Women in England in the Middle Ages. By Jennifer Ward. (New York, N.Y.: Hambledon Continuum, 2006. Pp. x, 283. \$60.00.)

Surveying medieval English women's experiences from the Anglo-Saxon period to the Reformation, this author divides her study into ten chapters conceptualized according to life stages, occupations, and class, with the themes of "women's worlds," marriage, wives and mothers, widows, work, noblewomen, queens, religious women, charity and lay religion, and (very narrowly construed) death. Although the chapter headings and topics Jennifer Ward has chosen signal impor- 
tant aspects of medieval women's lives in general, the choice has the dual effect of flattening out the appreciation of real change over time (history) and, unfortunately, giving a strong sense of repetition and redundancy from chapter to chapter (or even within chapters). Although some chapters are more chronologically organized than others, all too often historical examples are squeezed together. For example, King Alfred's mother and Eleanor of Castile are discussed in quick succession (53). Even though Ward reinforces the idea of continuity, the approximately five-hundred-year separation in time between Alfred and Eleanor undermines such continuity's significance, and is furthermore confusing.

Women's domestic and reproductive activities informed every aspect of their lives, from their participation in "work"-understood here as labor for pay (such as ale making) - to their religious and charitable practices. A queen's most important function was to become a mother, but domestic and maternal skills might be applied in the political and economic arena as well. Religious women also operated within a domestic framework, participating more actively in lay society than might be expected, performing important acts of charity and intercession, caring for the elderly and infirm, and burying the dead. Most interestingly, Ward demonstrates how "religious" women were not cut off from the world, but remained attentive to and active in their natal families.

Ward argues, contrary to suppositions that the Norman Conquest signaled the greatest social and political watershed for the English, that for women, the twelfth century and the years surrounding the Black Death were more important. The twelfth century saw marked changes in legal and governmental practice with the rise of the Plantagenets; after the Black Death, the economic and social changes that were wrought all over Europe also affected English women particularly.

This author synthesizes current scholarship but gives only a taste of the substantial work being produced by historians of medieval England and women. Ward enriches her narrative with reference to primary sources such as wills, letters, household accounts, and court records, and thus the book offers a good place to begin an exploration of medieval English women, if it does not give the final word on the subject. The writing style is clear; the illustrations of English tomb engravings and some photographs of monasteries are attractive but, lacking analysis, do not add much to the text. It is surprising that the cover illustration of the book reproduces a beautiful illumination from a French, not an English, manuscript. A brief glossary of English legal terms at the end of the book is very helpful. 
Ukraine: Birth of a Modern Nation. By Serhy Yekelchyk. (Oxford, England: Oxford University Press, 2007. Pp. xvi, 280. \$19.95.)

In this one-volume history of Ukraine, the author primarily focuses on the modern era. He details the events since World War I in eight out of eleven chapters. In the first three chapters, he provides a brief survey of the historical origins of Ukraine and the fate of Ukrainians in different empires up to the Russian Revolution of 1917. Although he does not explicitly state this, Serhy Yekelchyk attempts to carve out a niche for his book as different than two previously published Western histories of Ukraine, which are a history of the Ukrainian people (by Orest Subtelny) and a territorial history (by Paul R. Magocsi). The former approach has a long pedigree in Ukrainian historiography as best exemplified by the doyen of Ukrainian historians, Mykhailo Hrushevsky, though the latter is typical of western history.

Yekelchyk's approach is to provide a survey of the "Ukrainian national project" that aimed to build a modern Ukrainian nation in a national homeland (6). Though the overall historical survey is excellently written and eminently readable, the initial hypothesis that presents history in national terms leads to drawbacks. Yekelchyk believes that " $[\mathrm{m}]$ odern Ukraine is the result of a nationalist project, but it was not built by nationalists and was always a multinational state" (7). Independent Ukraine became possible by Soviet leader Jozef Stalin's unification of most lands where ethnic Ukrainians were in a majority.

The major weakness in a book that seeks to survey the "national project" is the limited discussion of Ukraine's regionalism and separatism, which is in many ways downplayed. The opposite has tended to be the case in Western scholarship; namely, an overemphasis on regionalism in the works of, among others, Quebecois scholar Dominique Arel, but it would be unwise not to place regionalism at the heart of any survey of the Ukrainian nation-building project. It is the case, as Yekelchyk writes, that the Ukrainian civic nation is emerging and that Eastern and Western Ukrainians see themselves as "Ukrainians." Many democratic states are also regionally divided (Canada, Belgium, the UK, Spain, Italy, Romania, Slovakia).

The Crimean separatist movement is too briefly covered (201). Yushchenko's perceived "nationalism" is wrongly discounted as a factor that will not turn away Eastern Ukrainian (Russophone) voters and regionalism's impact on voting habits (215). Different views of Ukrainian history and foreign policy orientations are insufficiently covered. Regionalism has become more pronounced since 2002 with the entry of the Donetsk clan into central Ukrainian politics and the victory of the 
Party of Regions (PR) in both the 2006 and 2007 elections. The PR, the most pro-Russian of Ukraine's centrist parties, dominates Eastern Ukraine but only obtains a brief mention (223-224).

Yekelchyk's survey is strongest when covering the Soviet period, especially different attitudes towards the nationality question in the Communist Party and plurality within the Ukrainian dissident movement. The 1932-1933 artificial famine and the unveiling of "blank spots" in Ukrainian history have become important in President Viktor Yushchenko's nation-building project, but this factor does not come through in the volume. Yekelchyk could have discussed three issues that are central: whether the famine was directed against Ukrainians or all Soviet peasants, if the famine was "genocide," and the relationship between Ukrainian integral nationalism and fascism.

Yekelchyk's critical survey of the post-Orange Revolution era is well balanced, although it might have been premature to include a prediction of Yushchenko losing the 2009 presidential elections (228). One final correction: only one reprivatization took place in post-Orange Revolution Ukraine (220). The book is overall the best introductory survey of Ukrainian history and includes a very good bibliography and index.

George Washington University

Taras Kuzio

\section{General, Comparative, Historiographical}

History and Freedom: Lectures 1964-1965. By Theodor W. Adorno. (London, England: Polity Press, 2006. Pp. xii, 348. \$24.95.)

This is a most challenging and thought-provoking work. It was first published in German as Zur Lehre von der Geschichte und von der Freiheit. In terms of methodology and mechanics, Theodor W. Adorno copiously employs Hegel throughout the book. However, this is not directly to support Hegel's views, but to use the idea of Hegel's dialectic in a somewhat different and contradictory context. Adorno rejects Hegelian theodicy. He frequently employs Kant in much the same way that he employs Hegel. Adorno is opposed to many of the conclusions of Hegel and Kant for the same reason; he does not believe that truth is something eternal, immutable, and ahistorical. History, for Adorno, is what human beings make of nature. This is unplanned because history cannot be consciously planned. Adorno's assumption, relating to history, is that free will, though randomly limited, is at the root of the philosophy of history, not moral philosophy. 
In order to explore the idea of the relationship between history and freedom it is important to understand Adorno's notion of the spell. Spell governs life as a will, and the interaction of the constantly changing historical process. At this point, a fundamental question raised by Adorno's work is: Is it possible to create any theory of history without some hidden idealism, thus finding meaning where there is none? Perhaps this may be explained in a somewhat different manner. Interaction is Adorno's explanation of the general course of history and the human position in history. He believes that no single person can resist the course of history. At the same time, the flow of history exerts itself through human beings. Another way of viewing the enigma of History and Freedom may aid in understanding it. Despite all of the suffering and evils the human race experiences and in which humankind seems to be helplessly immersed, this is also the locus of all the human hope and self-realization.

One of the most dominating portions in the book, and the chapter that implicitly and explicitly is reflected nearly everywhere in it, is chapter eight on psychology. Adorno emphasizes Freudian psychology. He points out that both the conscious and unconscious needs of humans are biologically determined. People unconsciously identify with the world or the flow of history to which they are contributing. Adorno calls this the irrational cement that holds the world as it exists.

At some points Adorno's work seems to struggle with author-created issues. These issues often seem unresolved and unrelated to the themes of the book. Individual examples of these are "The Nation and The Spirit of the People in Hegel," "The History of Nature II," and “The Concept of Progress II." Adorno also creates too many related terms that sometimes are used in a similar context. Examples of these terms are "spell," "spirit," "life process," "course of the world," and "the course of history." Although the book is arranged in chapters, it seems to meander rather than focus and integrate towards a single issue.

If it is possible to sum up a thesis from this book, it might be that history, though created by humans, tends to move on at its own inexorable pace, powerfully influencing all people. Individually, there is a symbiotic relationship between the march of history and the freedom of the individual. There is a small window of freedom that the individual has to alter the ongoing historical process. Freedom for the individual and the process of history interact as cause and effect. Through this tiny window they continue to alter history. 
Medicine, Emotion and Disease, 1700-1950. Edited by Fay Bound Alberti. (New York, N.Y.: Palgrave Macmillan, 2006. Pp. xxxiii, 196. \$65.00.)

This controversial book contains eight essays presented by medical historians, cultural historians, and historians of science at a workshop held at the Wellcome Trust Centre for the History of Medicine at University College London in October 2004. In the foreword, Professor Janet Browne assures readers that " $[\mathrm{t}]$ he papers published here engage with the management of emotion in the patient/physician relationship from the eighteenth century [onwards]" (ix).

Left unsaid is that this book is another attempt to achieve the "medicalization" of depression and other emotional "states." By "medicalization" the reviewer means the use of what purports to be "specialized knowledge" in order to encourage people with money in their pockets to employ the services of a medical doctor-or (nowadays) of the behind-the-counter agents of a pharmaceutical company-to "cure" a condition that the doctors (or the pharmaceutical company) claim is the result of an unnatural emotion, a symptom of mental disorder.

An impartial historian would find that many of these claims are bogus. In the natural order of things, nearly all people on occasion are liable to undergo emotional responses to outside stimuli that temporarily make them appear antisocial. Bruce Wexler-a highly reliable expert on brain, culture, and societyassures us that "[e]motion is an interindividual process that alters the momentary functional organization of the brain of the interactants, configuring and activating certain multiunit functional systems and dismantling and deactivating others" (34). In order to soothe a person troubled with an unpleasant, strong "emotion," what may be needed are the services of musicians, rather than for-profit medical doctors and pharmaceutical companies. In times past, this recommendation was made by persons as diverse as Alexander the Great and the Arab writer al-Hugwïi in his Kasf al-Mahgub. In our own time, in its issue of 1 March 2008, the Lancet reiterates this recommendation (listening to suitably selected music) for persons suffering from strokes. In short, "medicalization" has become somewhat suspect.

As many historians know, the first example of "medicalization" (not mentioned in the Alberti book) occurred in 1756 with the publication by Dr. S. A. A. Tissot (resident in Basel, Switzerland) of Ononia: Or a Treatise Upon the Disorders Produced by Masturbation. Renowned and trusted both for his Ononia and for his Advice to the People with Regard to their Health [1761], Dr. Tissot converted a perfectly harmless and perfectly natural activity by teenaged boys (and others) into a serious medical condition, which (he claimed) necessarily had to be treated by a medical expert-in return for a fee. 
Occurring at the beginning of the period covered by the Alberti book, Dr. Tissot's medicalization actions have been replicated on a gigantic scale in our own time by multinational pharmaceutical companies.

Medicalization is thus not all that it has been cracked up to be. This is another way of saying that readers of the Alberti book should hold it with well-insulated tongs and fireproof gloves.

Cairo, Egypt

Sheldon Watts

You Never Call! You Never Write!: A History of the Jewish Mother. By Joyce Antler. (New York, N.Y.: Oxford University Press, 2007. Pp. xii, 321. \$24.95.)

"You never call! You never write!" With this amusing and ironic title, this book is both a history of "the Jewish mother"-as durable cultural type-and a history of the Jewish mother as a real woman living in particular historical circumstances. On the one hand, Joyce Antler provides a wide-ranging and incisive analysis of how "the Jewish mother" became the scapegoat for an ever-changing repertoire of anxieties about modern life centering on assimilation, the parent-child relationship, and gender roles. On the other hand, Antler goes far deeper than the stereotype suggested by her title, probing the diverse nuances of manifold portrayals of Jewish women and the family in twentieth-century America.

Antler locates the origin of the negative stereotype in ambivalent popular cultural portrayals of immigrant Jewish mothers in the 1920s and 1930s. She demurs, however, on the question of why Jewish mothers, among all immigrants, attracted these concerns. Mothers were simultaneously praised for the sacrifices that made their children's success possible and criticized for the unhealthy attachments that seemed to accompany these sacrifices. This portrayal, bolstered by sloppy social science, soon skewed dramatically to the negative, with selflessness and toughness morphing into infantilization (usually emasculation) and manipulativeness. The apogee was the 1950s and 1960s, when the Jewish mother became the stand-in for all that was wrong with shallow, materialistic, suburban, bourgeois American culture-despite, Antler demonstrates, the very real personal and communal achievements of Jewish women of the time. Transferred from the familial context of 1950s Catskills humor to a larger American audience through the 1960s literary successes of Dan Greenburg and Philip Roth, the repulsive image of the suffocating, guilt-inducing Jewish mother became fixed in the American cultural landscape.

In the decades since, this toxic image has persisted in film and television portrayals, even as fiction, memoir, and academic study, informed by feminist 
insights, have created nuanced and sensitive representations of real women's lives. Antler cites as examples the plays of Wendy Wasserstein and writings by daughters about their Holocaust survivor mothers. She also argues that the stereotype has been subtly reconfigured, particularly in the work of Jewish female comedians. Given the centrality of comedy to the creation of the stereotype, it would be quite significant if in fact comedic treatment is now more "affectionate [and] respectful" (248). Antler is not entirely convincing here, although she legitimately points to social changes (intensive parenting in the middle class altogether and the changing demography of the American Jewish family) that are increasingly leaving the anxious Americanizing mother far behind.

This book is an important contribution to our understanding of both Jewish and women's history in twentieth-century America. Given the anti-Semitism and misogyny that often percolate from the stereotype of the Jewish mother, Antler rightly hopes that "[a]s contemporary American Jews become more confident and informed about their history, they can confront the distortions that arose from the anxieties of previous generations" (12). That will redound to the benefit of all American women.

California State University, Northridge

Amy Hill Shevitz

Evil Incarnate: Rumors of Demonic Conspiracy and Satanic Abuse in History. By David Frankfurter. (Princeton, N.J.: Princeton University Press, 2006. Pp. xii, 286. \$19.77.)

"Witchcraft" tends to be a catch-all word, embracing several different types of both benevolent and maleficent activity by men as well as women. One type is magical interaction between neighbors, or between client and practitioner, involving preternatural solutions to practical, everyday problems. Here there is no conspiracy, even if the magic is worked with the help of demons. Another type involves demons deliberately sent to obsess or possess individuals. A third manifests itself in the Sabbat, a meeting of humans and demons, presided over by Satan or another evil spirit, constituting a conspiracy between witches and the Devil to corrupt and overthrow human souls. It is this last that provides the author with one of the principal themes of his remarkably interesting book, the others being Jewish ritual murders of Christian children and the abuse and murder of women and children by groups devoted to Satan. These themes thus engage the Middle Ages, the early modern period, and the very recent past.

David Frankfurter sets out to answer the question, how does a myth (by which he means controlling narrative) of evil conspiracy get set in motion? Calling on the 
resources of modern psychology and sociology for assistance, he concludes that evil provides a context in which individuals and groups can project, act out, participate in, and repudiate those deviant behaviors they find both repellent and alluring. The organization and expression of disparate fears into coherent intellectual systems, which can thus be wedded to rituals intended to embody and act out the fears while simultaneously providing vehicles for their resolution and banishment, draws everyone in the engaged group or society to be a participant, active or passive, in the process. The myth of evil is thus given a structure and a coherence, which appears to underpin and illustrate its truth and provide a means whereby the disrupted group or society can reaffirm boundaries and effect its own purification and reintegration.

How far is this argument convincing? In suggesting that the course of such a "conspiracy" is set and controlled by experts in evil (priests, sociologists, exorcists, etc.), Frankfurter seems to teeter on the edge of implying that behind the conspiracy of evil is another, that of intellectuals against the common folk whose inchoate beliefs are structured and then used to their detriment. It is an impression most noticeably produced by his frequent eliding of the various types of witchcraft this reviewer mentioned earlier. Most accusations against witches do not involve the Sabbat at all; it was actually a fairly minor and rather odd phenomenon, not the norm. Frankfurter thus overplays his hand somewhat, and the reader can see signs of this in the occasional mistake. De Lancre's witchcraft treatise was not a manual, but a government report, and Institoris, author of the Malleus, was not pornographically obsessed $(71,205,209)$.

As a wide-ranging study of certain religio-sociological phenomena, Frankfurter's book is well worth reading and provides much food for thought. As a wholly satisfactory explanation of them, however, it does not altogether convince.

University of St. Andrews

P. G. Maxwell-Stuart

Rulers, Guns, and Money: The Global Arms Trade in the Age of Imperialism. By Jonathan A. Grant. (Cambridge, Mass.: Harvard University Press, 2007. Pp. 288. $\$ 49.50$.)

Some twenty years ago European historians began to integrate studies of the late-nineteenth-century imperial arms trade with their understanding of the coming of World War I. The author of this study incorporates this literature with his own extensive but selective primary research; he has produced something more than a synthesis of the complex relationship among manufacturers selling 
weapons of war, the great powers, and lesser states on the receiving end of the sales. Jonathan A. Grant also informally tries to test the views of international relations theorists and political scientists who have looked at the connections between states and the war business in the contemporary world. Grant's writing is intelligent, but difficult, and although he tells an overly compressed and complicated story, the reader will find it rewarding.

In general the work of Grant and like-minded scholars only changes the history of the European colonial powers at the edges. Competition among the nationstates drove global politics from 1870 to 1914 , but this is a blunt way to examine matters. Businessmen in various locales developed an outlook sometimes at variance with that of the politicians in their home countries, and these capitalist entrepreneurs sometimes acquired what amounts to a nascent vision in which their international interests may have trumped their loyalties to their states. Minor nations, in their own quest for military prestige, may have inveigled the great powers and their munitions dealers to participate in activities that statesmen would otherwise have clearly eschewed.

Grant covers a great deal of territory. He begins with the brief success of American gun manufacturers in the aftermath of the Civil War in selling their product overseas. Yet in the New World most of his time is spent in chronicling the way in which commercial arms traders and officials in Argentina, Brazil, and Chile contributed to a series of naval and arms races in South America. These contests seem to have had no purpose except to exhibit the foolishness of the Latin leadership and the inability of the great European powers to pursue what might be considered a rational set of policies.

In Europe itself, the book investigates the intricate rivalries among Germany, Russia, and France within the Balkans, in the Ottoman Empire, and in North Africa. Here, the sellers of weapons both fostered instability among the great nations and gave smaller states the ability to thwart imperial aims and to maintain a modicum of leverage.

Finally, the author examines in Asia the more well-known case of the military transformation of Meiji Japan, although China also gets some mention. In the explosion of a global market in guns at the end of the nineteenth century, Japan appears to have been the one clear winner, but her rise to martial might was also just one dimension of her modernization.

This demanding book will repay careful study, but the author makes few concessions to his readers.

University of Pennsylvania

Bruce Kuklick 
The Spice Route: A History. By John Keay. (Berkeley, Calif.: University of California Press, 2006. Pp. xv, 288. \$40.00.)

A spate of fine books about spices has inexplicably been published recently, including Jack Turner's Spice, Michale Krondl's The Taste of Conquest, Paul Freedman's Out of the East, and the present volume. Readers interested in food history should not be misled by the inclusion of this book in a food series. It is a history of maritime exploration, incidentally concerned with the spices themselves. In fact, the author is sometimes uninformed about how spices are used and sometimes even what they are.

Readers are told that cloves and nutmegs "entered the purview of the Roman world through India's west coast ports" $(13,14)$. Later, John Keay admits that Pliny uses the name "caryophyllon" but so thoroughly misdescribes them as a big grain, like pepper, that he probably never saw a clove (76). Then readers are grudgingly informed that only in the sixth century are cloves mentioned by Aëtius (84). Aëtius was a Byzantine scholar from Mesopotamia, and surely that is where he saw them. So the Romans never knew cloves after all, which one could have found out quickly with a glance at Andrew Dalby's Dangerous Tastes, in this same series. Is this important? It is if one is trying to argue that the ancient trade routes extended from Indonesia to Italy. Clearly they did not.

Other errors abound. Musk is hardly "foul-smelling" nor was it "unwelcome in the kitchen" (21). Dozens of recipes call for musk, stretching from the late Middle Ages through the early modern era. Cubebs are not a kind of pepper (26). They are in the same genus, but a completely different species. Malaguetta pepper or grains of paradise are not pepper at all, nor are they "with a tail" (150). That is cubebs. Labdanum is a perfumed resin of Cistus ladanifer, a type of rock rose; Keay spells it ladanaum, which seems to be a misspelling of laudanum, an opiate not in use until the sixteenth century (26).

Keay also makes a noble attempt to dispel the "long-held belief that spices were essential in the preservation of butchered meat" (27). No one in the past ever made any such claim. The misconception is that spices were used liberally to cover the odor of rancid meat, made by food historians such as Drummond in The Englishman's Food and repeated ad nauseum until recently. But no medieval or early modern person ever believed this.

This author also promises a new approach to the study of the spice routes, from the perspective of the producers outward rather than the end consumers, and perhaps a new configuration of "the accepted chronology of Greco-Roman, Indo-Arab, Portuguese-Spanish and Anglo-Dutch periods." The author follows 
this chronology precisely, because it is the only one possible given the sources. Lip service is paid to the Chinese, Persians, and Africans—as it must be. But in the end this is still basically the same story of maritime discovery as told elsewhere. The Moluccans, Sri Lankans, and other people savvy enough to export these spices are still as shrouded in mystery as they were centuries ago.

These mostly food-related quibbles aside, the author does do a very good job introducing the major players and sources, and telling the narrative of what is a stupendously fascinating topic. It would have been nice to have maps that correspond to the minutiae of the text rather than a few continents, and at times the place names are both dizzying and inscrutable. Despite all this, The Spice Route is still one truly engaging and accurate account of the geographical history of the spice trade. The introduction is so gorgeously written that one cannot help but swoon at the intoxicating prose, which can only be described as spicy. For a solid, well-written overview of how spices travel, this is indeed the book.

University of the Pacific

Ken Albala

A History of Human Beauty. By Arthur Marwick. (London, England: Hambledon, 2004. Pp. xi, 276. \$24.95.)

This study is the last book by the late, prolific British social historian Arthur Marwick, who seeks to understand how beauty "is recognized as an independent personal characteristic" in Western culture (225). Marwick rigorously defines beauty apart from the attributes of wealth and power, with which it is often confused. Although many styles of beauty exist, it is independent of fashion and, far from being culturally constructed, has maintained great consistency throughout the Western world over many centuries. Beauty is a rare commodity; it affects sexual attractiveness but it is not the only condition necessary for sexual allure.

Marwick traces the ways in which Westerners have valued beauty across time. He considers the Platonic view of true beauty, which relates to virtue, a "confused spiritual message," and chooses to focus on "bodily beauty" alone (30). Marwick wishes to discover how beautiful people have used their appearance to gain advantages in their lives, observing, "For good or for ill...they will have opportunities not open to others" (59). Throughout most of history, beautiful people, both male and female, have had to cash in their physical attractiveness through sex and have not necessarily had happy lives. Marwick uses the courtesans of European monarchs as examples, including the young men favored by Catherine the Great. Many of these courtesans, such as Madames de Pompadour and du Barry, were born commoners and attained their influence in court solely 
because of their physical attractiveness. In the eighteenth and nineteenth centuries, beautiful women with lesser social standing could find work as servants, salesgirls, actresses, or prostitutes. Women known as "grandes horizontales" (e.g., Cora Pearl) used their beauty, with sex, to carve out their existences on the edges of wealthy European society.

But being beautiful has its limits. It does not necessarily lead to happy marriage; for most humans, an optimal spouse has many attributes that do not include physical appearance. Marwick examines British prime ministers and American presidents and finds that, before television, beauty had little role in political power.

Mass media has changed the role of beauty in Western culture. With the advent of movies, television, and modeling, a beautiful person sells his or her sexual attractiveness instead of actual sex. This shift has made beauty as powerful as class and wealth. Finally, beautiful people can attain power by marketing their appearance but not their actual bodies.

A History of Human Beauty is a quick romp through multiple centuries, pausing in some unsavory places in Europe and America. Overall, it is the work of a supremely confident historian, one who is able to make vast leaps in time, space, and topic in search of an abstract concept. The book continues in dialogue with Marwick's prior work. He routinely takes pot shots at feminists, evidently as part of a long-standing feud between him and his critics. Ultimately, it brings to readers' attention a group of people who, with the biological gift of a pretty face, attained worldly note that they otherwise would not have had.

Texas Christian University

Rebecca Sharpless

Revolutions and the Collapse of Monarchy: Human Agency and the Making of Revolution in France, Russia, and Iran. By Zhand Shakibi. (New York, N.Y.: I.B. Tauris, 2007. Pp. 256. \$74.95.)

This work is a comparison of three major revolutions: the French Revolution, the Russian Revolution, and the Iranian Revolution. For each of these revolutions there is a huge body of literature in all major languages. Still, the author has brought some important insights to the understanding of the events. The vast majority of Western historians usually assume that the entire course of revolution and, even more so, the reason why these revolutions started at all, can be explained in the context of what could be called "structure": the state and the various social groups ("classes," to use Marxist parlance). The goal of the rulers- 
the French king, Russian tsar, and Iranian shah-is either ignored or viewed in passim.

The reason for this assumption is that Western society, especially American society, is, indeed, a society of "structures." The role of the executive, both in defining internal developments and foreign policy, is often quite limited, regardless of the illusion of those engaged in the process. One might add that George W. Bush's foreign policy is not so much connected with that of Ronald Reagan, regardless of statements often made, but rather with that of Clinton, who actually invented the policy of "preventive wars" (the war against Yugoslavia/Serbia). This is quite different from premodern and non-Western societies, where it was or is not "structure" but "persons"- the leaders—who matter in defining the course of events. Or, to be precise, their role is far from negligible. And this is the point of the author. He illustrates that it was the personality of the king, tsar, and shah that was most important. Moreover, he implicitly induces the observer to look not just to the personality of the rulers but to their actions or nonactions-for example, their unwillingness to employ force at the proper moment-to a sort of "molecular," detailed picture of history, which is the job not of historians but of writers. And he suggests that some of these actions or nonactions, usually overlooked by historians with the desire to "socialogize" history, could be momentous for unfolding events. Although he has important insight and makes good points, the author does not carry his idea through to a good conclusion. The reader should fish this out through ideas in the body of the narrative. A more focused or, one might say, provocative narrative without so much well-known material would have considerably improved this book. 